
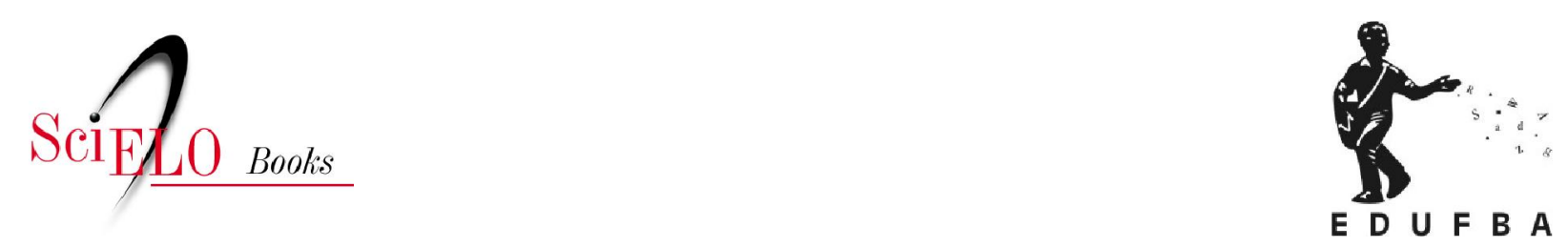

\title{
Comunicação plural
}

\author{
Sérgio Mattos (org.)
}

MATTOS, S., org. Comunicação plural [online]. Salvador: EDUFBA, 2007. Saladeaula series, $\mathrm{n}^{\circ} 4$.

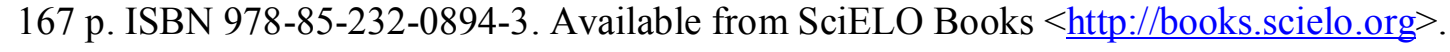

\section{(c)}

All the contents of this chapter, except where otherwise noted, is licensed under a Creative Commons Attribution-Non Commercial-ShareAlike 3.0 Unported.

Todo o conteúdo deste capítulo, exceto quando houver ressalva, é publicado sob a licença Creative Commons Atribuição - Uso Não Comercial - Partilha nos Mesmos Termos 3.0 Não adaptada.

Todo el contenido de este capítulo, excepto donde se indique lo contrario, está bajo licencia de la licencia Creative Commons Reconocimento-NoComercial-CompartirIgual 3.0 Unported. 
Comunicação Plural 

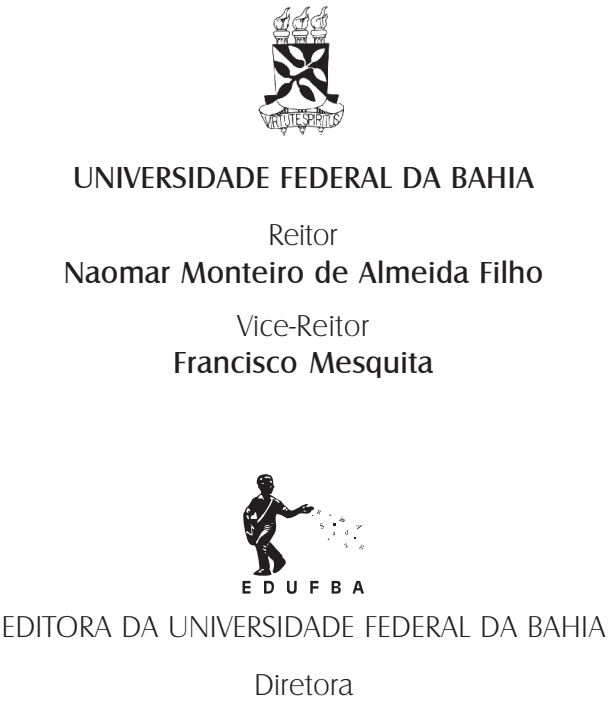

Flávia Goullart Mota Garcia Rosa

\author{
Conselho Editorial \\ Angelo Szaniecki Perret Serpa \\ Carmen Fontes Teixeira \\ Dante Eustachio Lucchesi Ramacciotti \\ Fernando da Rocha Peres \\ Maria Vidal de Negreiros Camargo \\ Sérgio Coelho Borges Farias \\ Suplentes \\ Bouzid Izerrougene \\ Cleise Furtado Mendes \\ José Fernandes Silva Andrade \\ Nancy Elizabeth Odonne \\ Olival Freire Júnior \\ Sílvia Lúcia Ferreira
}




\title{
Comunicação Plural
}

\author{
Sérgio Mattos
}

Organizador

saladeaula 4

EDUFBA

Salvador, 2007 
(C) 2005, by autores

Direitos para esta edição cedidos à EDUFBA.

Feito o depósito Legal.

Projeto gráfico

\section{Alana Gonçalves de Carvalho}

\section{Editoração Eletrônica e arte final}

Letícia Miranda

\section{Preparação de Originais e Revisão de Texto \\ Tania de Aragão Bezerra Magel Castilho de Carvalho}

\section{Biblioteca Central Reitor Macêdo Costa - UFBA}

C741 Comunicação plural / Sérgio Mattos, organizador ; [autores: Flávia G.

M. G. Rosa, Giovandro Marcus Ferreira ... [et al.]. - Salvador:

EDUFBA, 2007.

167 p. : il. - (Saladeaula ; 4)

ISBN 978-85-232-0442-6

1. Comunicação - Estudo e ensino - Brasil. 2. Televisão - História Brasil 3. Telejornalismo. 4. Imagens fotográficas. 5. Análise do discurso.

6. Comunicacão escrita. 7. Artes gráficas - História. 8. Livros - Edições piratas. I. Mattos, Sérgio. II. Rosa, Flávia Goullart Mota Garcia.

III. Ferreira, Giovandro Marcus.

\section{EDUFBA}

Rua Barão de Geremoabo, s/n

Campus de Ondina, Salvador-BA

CEP 40170-290

Tel/fax: (71) 3263-6164

www.edufba.ufba.br

edufba@ufba.br 


\section{Sumário}

Apresentação do livro... 7

Sobre os autores... 13

O ensino da Comunicação... 17

José de Marques de Melo2

O resgate da memória...33

Sérgio Mattos

A construção dos âncoras nos telejornais... 51

Valério Cruz Brittos e Paloma Rühee

Análise da imagem na imprenssa... 73

Giovandro Marcus Ferreira

O receptor em questão... 93

João José Santana Borges

A arte sutil da tipografia... 111

Matilde Eugênia Schnitman

Cópia de livros... 143

Flávia G. M. G. Rosa, Susane S. Barros e Nanci Oddone 



\section{Apresentação}

do Livro

No ano de 2005, o ensino da comunicação no Brasil completou 70 anos. Em seu início, o ensino era baseado em literatura estrangeira, importada principalmente dos Estados Unidos. A partir da década de 1940 começou-se a construir uma pedagogia da comunicação adaptada à nossa realidade e às nossas necessidades. Mesmo assim o ensino da comunicação estava atrelado aos currículos mínimos impostos pelo MEC. Nas últimas três décadas, pesquisadores têm concentrado seus estudos nos fenômenos de comunicação brasileiros, contribuindo direta e indiretamente para a aprovação de uma Nova Lei de Diretrizes da Educação que permitiu uma maior liberdade curricular. Entretanto, os impasses persistem, o que tem apontado para a necessidade de se ampliar o debate crítico sobre o ensino da comunicação.

O ensaio do professor doutor José Marques de Melo, atual presidente da Intercom, que levanta questões sobre o ensino da comunicação, discutindo alguns desafios que se apresentam para a sociedade contemporânea, é o texto que abre este livro devido à sua pertinência e atualidade. Em seu trabalho, Marques de Melo apresenta os marcos históricos do ensino da comunicação; identifica os padrões de referência; aponta as tendências de acomodação aos modelos importados; registra que no Brasil já existem mais de 500 cursos de comunicação em nível de graduação; e, entre outros pontos, constata que existe uma grande defasagem entre a pesquisa institucionalizada e as necessidades de conhecimento por parte do setor produtivo. Ele aponta para a necessidade de se repensar criticamente as estratégias de produção de conhecimento comunicacionais destinados à formação dos profissionais midiáticos. Exatamente por isso seu ensaio responde a questões como: O que ensinar aos jovens? Discutindo temas como conceitos comunicacionais, processos midiáticos e conteúdos culturais. Que estratégias pedagógicas devem ser assumidas? Entre as possíveis solu- 
ções, ela aponta: Aumentar a sintonia entre os processos didáticos e a natureza de cada curso; ampliar a disponibilização de equipamentos e laboratórios para cada seǵmento profissional; e evitar o provincianismo no ensino e na formação profissional. Estes são alguns dos desafios apresentados pelo artigo de abertura o que estimula o debate nas salas de aulas nos cursos de graduação e pós-graduação.

Também preocupado com o ensino e a produção de conhecimento da comunicação, apesar de mais específico, o segundo artigo deste livro, "O resgate da memória e a construção da história da televisão no Brasil", de Sérgio Mattos, tem como objetivo levantar questōes sobre a importância da memória da mídia televisão no Brasil, como processo de construção de conhecimento da área da comunicação. Os estudos acadêmicos sobre a televisão brasileira foram praticamente iniciados em fins da década de 1960 e intensificados a partir da década de 1990, com a multiplicação dos cursos de pós-ğraduação e pela criação de Grupos de Trabalho e Núcleos de Estudo, em instituições como a Intercom e em várias faculdades do país. Este trabalho identifica pontos relevantes no levantamento histórico descritivo da televisão e dos nomes dos profissionais que contribuíram para o avanço e a solidificação do setor. Trata-se de uma reflexão crítica sobre a importância da historiografia midiática no papel de construção do campo da comunicação, mais especificamente da televisão brasileira. Destaca ainda a historiografia midiática como uma tarefa coletiva de longo prazo e tenta identificar aspectos essenciais que contribuam para o resgate da memória histórica da televisão em todas as regiōes do país. Em síntese este artigo instiga o debate sobre o tema, apresentando questões sobre a mídia TV e uma longa lista contendo sugestões de temas que ainda precisam ser trabalhados e que podem servir de inspiração para futuras monografias, dissertações e teses.

Como uma seqüência dos estudos sobre a televisão, no terceiro artigo deste livro, Valério Cruz Brittos e Paloma Rühee realizam um estudo sobre o telejornalismo, mais especificamente analisam a construção da figura do âncora pela Rede Globo. Isto porque a Globo tem, ao longo dos anos, construído de diversas formas discursivas os apresen- 
tadores dos seus telejornais. A Globo molda cada apresentador de acordo com o público de cada telejornal. No telejornalismo compete ao âncora o papel de interligar os acontecimentos dentro do telejornal e tentar a interação do conteúdo noticioso. O trabalho de Brittos e Rühee é importante para que os estudantes de comunicação entendam a figura do âncora, pois, como os autores afirmam, este é um "passo importante para entender o telejornalismo brasileiro e perceber toda a linguagem discursiva de uma emissora".

Como o artigo anterior trata da linguagem discursiva do telejornalismo, a análise do discurso passa a ser foco de interesse neste livro o que veremos nos dois próximos trabalhos. O quarto artigo, de autoria do atual Diretor da Faculdade de Comunicação da UFBA, Giovandro Ferreira, apresenta uma exposição sobre alguns aspectos em que a imagem foi objeto de estudo no interior das teorias da comunicação, em especial a partir da semiologia e da análise do discurso. Num primeiro momento, ele expõe, recorrendo à história, a polissemia em que se encontra eivada a noção de imagém, o que já deixa pista da elasticidade deste termo. Em seguida, o autor se concentra a trabaIhos que analisam a imagem e o texto, sobretudo na fase imanentista da semiologia, que buscava a criação de uma semiologia da imagem ou uma semiótica visual. Por fim, ele posiciona o estudo da imagem, no caso da fotografia, no interior não de uma semiologia visual pretendida, mas de uma nova fase da análise do discurso. Esta nova fase busca articular as diferentes matérias significantes, entre elas, a fotografia - agora inserida em novos contextos, ou seja, nas suas condições sociais de produção e reconhecimento.

Por sua vez, João José de Santana Borges apresenta, no quinto trabaIho deste livro, algumas notas sobre as contribuiçōes da análise de discursos para a teoria da comunicação. O ensaio aborda o receptor, como objeto e sujeito na cordilheira das abstrações, apresentando, no final, um desafio que consiste em fazer uso das categorias de Análise de Discursos para compreender o processo interpretativo dos alunos face às disciplinas teóricas do ensino da comunicação. 
O sexto ensaio incluído neste livro é sobre Artes gráficas. Trata-se do artigo "A Arte Sutil da Tipografia", de autoria de Matilde Eugenia Schnitman que apresenta uma evolução do desenho das letras do alfabeto romano, que deu origem a varias grafias no mundo ocidental. O artigo analisa a tipografia romana, durante e após o Império Romano, passando pelos séculos XIX e XX até os dias atuais. No século XIX as Artes Gráficas passaram a ocupar um lugar de destaque no processo de desenvolvimento dos países. O século XIX foi o século da fotografia, da máquina de escrever, das primeiras máquinas de composição tipográfica (linotipo e monotipo), dos primeiros jornais impressos em rotativas e do cinema. Em seu trabalho, Schnitman desvenda ainda aspectos da tipografia e o uso da mesma pelas artes plásticas. Discute a relação entre a arte e a tipografia, "ambas instrumento de comunicação em suporte palpável por mais 3.500 anos e agora tem como suporte a luz emanada de uma tela, um suporte impalpável, para não usar o termo 'virtual'".

Encerrando o livro, o texto intitulado "Cópia de livros nas universidades brasileiras", de autoria de Flávia Garcia Rosa, Susane S. Barros e Nanci Oddone, levanta um dos temas mais polêmicos atualmente dentro das universidades e responsável maior pelo elevado preço de capa cobrado pelas editoras. Segundo as autoras, desde outubro de 2004, quando o Conselho Nacional de Combate à Pirataria e Delitos contra a Propriedade Intelectual foi criado no âmbito do Ministério da Justiça, a prática de copiar livros ou partes de livros para uso em disciplinas universitárias de graduação e pós-graduação tem agiitado o meio acadêmico brasileiro. Como resultado das controvérsias suscitadas em torno da questão, o deputado Antonio Carlos Mendes Thame submeteu à Câmara, em abril de 2005, o Projeto de Lei 5.046, que autoriza a reprodução de livros, desde que sem fins comerciais, para uso exclusivo de estudantes universitários. A Associação Brasileira de Direitos Reprográficos, que reúne algumas das mais importantes editoras do país e atua como "entidade fiscalizadora e repressora da reprodução ilegal das obras de seus associados", por sua vez, dispõe- 
se a intensificar a luta contra a "pasta do professor". O estudo aqui apresentado tem o objetivo de compreender as diferentes variáveis que determinam o fenômeno das cópias de livros no meio acadêmico e identificar as propostas de ação que vêm sendo sugeridas pelas instituições de ensino universitário na tentativa de solucionar o problema e cumprir a legiislação sem prejudicar o ensino ou onerar o custo da formação profissional para os estudantes. Como o aluno é uma das partes mais interessadas no processo, se justifica a inclusão do texto neste volume, não apenas pelo aspecto de conscientização que ele permite, mas também porque abre perspectivas para novos debates com relação ao tema no meio universitário.

Para a realização deste livro foram mobilizados professores e pesquisadores, especializados nos temas selecionados além de uma jornalista profissional e uma graduanda com bolsa de iniciação científica. Todos têm algum vínculo com a UFBA, onde se graduaram, realizaram estudos de pós-graduação ou ainda estão atuando, seja como aluno de pós graduação, professor, orientador de teses e dissertações ou participando de bancas de avaliação. O livro "Comunicação Plural" atinge plenamente a pluralidade buscada e demonstra que apesar da diversidade temática existe uma interatividade entre os mesmos, constituindo-se como um volume de suma importância para o enriquecimento de conteúdo no processo ensino-aprendizagém da comunicação nas salas de aula das faculdades. Espera-se que os temas abordados contribuam para estimular o debate crítico necessário no campo das comunicaçōes e que sejam instigantes a ponto de gerar novas reflexões.

Sérgio Mattos

Organizador 



\section{Sobre os autores}

\section{Flávia G. M. G. Rosa}

Diretora da Editora da Universidade Federal da Bahia - EDUFBA. Professora da Escola de Belas Artes da UFBA. Meste em Ciência da Informação pelo Instituto de Ciência da Informação da UFBA. Diplomada em Jornalismo pela FACOM/UFBA.

\section{Giovandro Marcus Ferreira}

Diretor da Faculdade de Comunicação da Universidade Federal da Bahia. Professor e pesquisador na FACOM, onde ministra disciplinas de Teorias do Jornalismo e Teorias da Comunicação, no curso de graduação em Comunicação, e também orienta e leciona (mestrado e doutorado) no Programa de Pós-graduação em Comunicação e Cultura Contemporâneas. É graduado em Filosofia (PUC-MG) e em Comunicação Social - Jornalismo (UFES), e se tornou mestre e doutor em Ciências da Informação pelo Instituto Francês de Imprensa e Comunicação (IFP), na Universidade Paris II (Panthéon-Assas). Foi até 2006 coordenador do Núcleo de Pesquisa "Teorias da Comunicação" da INTERCOM e já publicou diversos artigos em revistas e livros inscritos na área de Comunicação.

\section{João José Santana Borges}

Bacharel em Relações Públicas e Mestre em Comunicação e Cultura Contemporâneas pela UFBA, professor de Teorias da Comunicação para o curso de Relações Públicas e Legiislação e Ética em Jornalismo e RP da UNIBAHIA.

\section{José Marques de Melo}

Professor Titular da Universidade Metodista de São Paulo, onde é Diretor da Cátedra UNESCO de Comunicação. Doutor e livre-docente em Ciências da Comunicação-Jornalismo pela Universidade de São Paulo (1973). Graduado em Jornalismo pela Universidade Católica de Pernambuco (1964) e em Ciências Jurídicas e Sociais pela Universidade Federal de Pernambuco (1965). Autor de meia centena de livros e 
coletâneas e mais de cem artigos em periódicos científicos do país e do exterior. Fundou e dirigiu sociedades científicas e espaços iberoamericanos. Tem experiência na área de Comunicação, com ênfase em Jornalismo brasileiro, gêneros jornalísticos, pensamento comunicacional latino-americano e história das ciências da comunicação.

\section{Matilde Eugênia Schnitman}

Bacharel em Jornalismo pela UFBA, Mestre em Administração/Gestão Integrada na Organização pela UNEB/Unibahia. É especialista em produção editorial pela UCSal e professora das Faculdades Integradas Ipitanga/Unibahia. É autora do livro Monografia: de Bicho papão a manso gatinho, 2004, e da dissertação "A Palavra como ferramenta de gestão", em 2003.

\section{Nanci Oddone}

Doutora em Ciência da Informação. Professora do Instituto de Ciência da Informação da UFBA. Coordenadora do projeto de pesquisa em andamento "Política nacional de informação científica e tecnológica: avaliação do Portal de Periódicos da CAPES."

\section{Paloma Rühee}

Jornalista, graduada pela Universidade do Vale do Rio dos Sinos (UNISINOS). Participou do 16 SET Universitário da PUC-RS, onde tirou o $1^{\circ}$ lugar na categoria Jornalismo Gráfico, subcategoria reportagem, com o texto Longe do Abandono. Também participou da 11 a Expocom - Exposição da Pesquisa Experimental em Comunicação, tendo recebido menção honrosa pelo vídeo-documentário Uma vida em versos.

\section{Sergio Mattos}

Professor Doutor aposentado da FACOM/UFBA e atual diretor-Coordenador da Pós-grraduação, Pesquisa e Extensão das Faculdades Integradas Ipitanga/UNIBAHIA, onde coordenou até 2005, os cursos de Comunicação Social com habilitações em Jornalismo e Relações Públicas. É graduado em Jornalismo pela UFBA, Mestre e Doutor em Comunicação pela Universidade do Texas, Austin, Estados Unidos. É autor de 27 livros. Ex-presidente e diretor do IRDEB, Ex-presidente do IBL - Instituto Baiano do Livro- e ex-presidente da ALAS - Academia 
de Artes e Letras do Salvador. Em 2000 recebeu o Prêmio Luiz Beltrão de Ciência da Comunicação, na categoria de Maturidade Acadêmica, outorgado pela Sociedade Brasileira de Estudos Interdisciplinares da Comunicação - INTERCOM.

\section{Susane S. Barros}

Graduanda em Biblioteconomia pelo Instituto de Ciência da Informação da Universidade Federal da Bahia. Bolsista de Iniciação Científica/CNPq.

\section{Valério Cruz Brittos}

Professor no Programa de Pós- graduação em Ciências da Comunicação da Universidade do Vale do Rio dos Sinos (UNISINOS), onde coordena o Grupo de Pesquisa Comunicação, Economia Política e Sociedade (CEPOS), e Doutor em Comunicação e Cultura Contemporâneas pela Faculdade de Comunicação (FACOM) da Universidade Federal da Bahia (UFBA). É presidente do Capítulo Brasil da União Latina de Economia Política da Informação, da Comunicação e da Cultura (ULEPICC-Brasil) e editor da revista acadêmica Eptic On Line (mww.eptic.com.br). 



\section{O ensino de Comunicação}

Os desafios da sociedade contemporânea ${ }^{1}$

José Marques de Melo

\section{Introdução}

O ensino de comunicação volta ser discutido intensamente pela comunidade acadêmica brasileira. Este foi, por exemplo, o tema central do XXVIII Congresso Brasileiro de Ciências da Comunicação, realizado no Rio de Janeiro, em setembro de 2005.

Tal fenômeno reflete inegavelmente a agenda da presente conjuntura. Ela é marcada pela tramitação da reforma universitária no Congresso Nacional. Capitaneado pelo Ministério da Educação, o projeto vem suscitando polêmicas acaloradas. Outro estigma tem sido a expansão da rede nacional de educação superior. Essa tendência tem provocado reações das corporações profissionais, que vislumbram a saturação do mercado de trabalho. Temese que o exército da mão de obra de reserva venha 
a ser reforçado por jovens com diploma, mas sem emprego. A propósito disso, a Federação Nacional dos Jornalistas protocolou demanda junto ao Ministério da Educação, reivindicando "moratória" para os cursos de jornalismo, com a justificativa do seu crescimento desordenado.

O cenário também evidencia a perplexidade dos educadores da área, cujas lideranças vacilam perante a liberdade curricular instituída pela nova Lei de Diretrizes e Bases da Educação Nacional. Muitos professores carecem de segurança para ousar pedagogicamente, deixando de construir grades curriculares sintonizadas com as demandas regionais ou locais. Alguns demonstram nostalgia em relação ao "currículo mínimo" dos tempos autoritários. O argumento sugerido é profundamente comodista: as "regras do jogo" antes definidas em Brasília facilitavam o trabalho de organização didática, em função do elenco de disciplinas obrigatórias.

A verdade é que, apesar de terem conquistado o direito de inovar os projetos pedagógicos dos respectivos cursos, vários professores de comunicação, ocupantes de funções dirigentes, demonstram inapetência para o exercício da liberdade, preferindo acomodar-se aos modelos adotados pela burocracia acadêmica ou sutilmente impostos pelas "vanguardas" que integram as comissões verificadoras do Ministério da Educação.

Para entender melhor tais contradições, torna-se importante fazer um retrospecto histórico do ensino de comunicação. Vale a pena retomar também a questão central que permeia este debate. Ela se ancora na frágil identidade do campo comunicacional dentro do espaço universitário. 


\section{Marcos históricos}

Embora demandada pela corporação jornalística, desde o início do século XX, a formação profissional na área de comunicação somente se concretizou na conjuntura do pós-guerra. Foi exatamente em 1947, no bojo do processo de redemocratização nacional que se instalaram os primeiros cursos universitários. Primeiro em São Paulo (1947) e depois no Rio de Janeiro (1948).

Esses projetos pioneiros replicavam os paradigmas vigentes naquela época. A experiência paulista alinhava-se mais com o modelo norte-americano (RIZZINI, 1952). Enquanto isso, o empreendimento carioca demonstrava maior sintonia com o modelo francês (JOBIM, 1960). Ambos espelhavam a carência nacional no campo informativo, principalmente porque as empresas jornalísticas, libertadas das garras da censura instaurada pelo Estado Novo, sentiam-se motivadas a ocupar os espaços abertos pelo regime democrático. Para dinamizar suas atividades e gerar produtos diferenciados, necessitavam de novos profissionais, não mais improvisados nas redações, mas educados nos bancos universitários. (MARQUES DE MELO, 1974)

A década de 50 testemunhou a ampliação dessa área do conhecimento pelas regiões sudeste (Santos) e sul (Porto Alegre, Pelotas e Curitiba), bem como pelo nordeste (Salvador e João Pessoa). Isso ocorreu apesar da reação desencadeada pelos velhos profissionais. Estes refugavam ostensivamente os jovens jornalistas diplomados, receando a competição inevitável no mercado de trabalho Mas foi, sobretudo, na década de 60 que houve uma significativa expansão do ensino. O número de instituições triplicou, perfazendo o total de 23 escolas de superior que ofereciam cursos de comunicação. Não apenas no segmento do jor- 
nalismo, mas também da publicidade, cinema, relações públicas, radio e televisão, etc. (MARQUES DE MELO, 1976)

Tal mudança refletiu a pujança da nossa indústria midiática. Ela passou a exigir profissionais qualificados em diversas áreas da produção simbólica, da informação à persuasão, do entretenimento à teleducação. As primeiras faculdades de comunicação (Brasília, São Paulo e Porto Alegre) correspondem a esse cenário desafiador, não obstante as restrições impostas ao processo criativo pelo golpe militar de 1964.

\section{Padrões de referência}

Verifica-se, em função disso, uma forte atração da comunidade universitária pelos padrões forâneos de produção e difusão intelectual, numa tentativa de refluir às limitações impostas pelo regime autoritário.

A conjuntura exigia da universidade não somente a formação de quadros para as empresas de comunicação massiva, demandando igualmente a reflexão sobre os fenômenos desencadeados pelos fluxos culturais que acarretavam a "modernização reflexa” da sociedade brasileira (RIBEIRO, 1972).

Essa tarefa foi enfrentada pelos primeiros programas de doutorado implantados em Brasília e São Paulo, de acordo com os hegemônicos padrões europeus, depois atualizados pela adoção do sistema norte-americano que instituiu o mestrado como etapa prévia ao doutorado. O novo modelo é implantado pelas universidades paulista (USP e PUC), carioca (UFRJ) e também pela emblemática universidade brasiliense (UnB).

Desde então, impôs-se uma tendência de acomodação aos modelos educacionais impostos pelos governos militares, ora 
abertos à importação de paradigmas (principalmente através dos quadros intelectuais formados em universidades estrangeiras), ora refratários aos padrões dominantes, cultivando modelos mistos, que agregavam às tradições nacionais os modismos oriundos d'além mar.

Mas o traço dominante nesse período que culmina com o esgotamento do ciclo militar, foi certamente a expansão vertiginosa da nossa rede de ensino, através da abertura da universidade ao investimento privado. As carreiras de nível superior multiplicaram-se em todo o território nacional, sendo a área de comunicação uma das mais exploradas.

Os cursos de graduação ultrapassaram o patamar das cinco centenas no início do século XXI (CALDAS, 2003). Esse crescimento também foi registrado na pós-graduação, elevando-se para duas dezenas o número de programas que oferecem cursos de mestrado e/ou de doutorado. (COMPÓS, 2005)

Existe uma grande concentração da rede de ensino de comunicação na região Sudeste (CALDAS, 2003). De cada 10 cursos de comunicação existentes no país, seis estão situados nessa região (61\%). A fatia restante está distribuída pelo Sul (19\%), Nordeste (11\%), Centro-Oeste (7\%) e Norte (2\%).

\section{Identidade vacilante}

Da mesma forma que existe uma assimetria espacial, dentro do território brasileiro, outros paradoxos emergem no panorama contemporâneo da área. Um dos mais importantes é o descompasso entre a graduação e a pós-graduação. Também merece atenção a dissonância entre as grades curriculares e os conteúdos das disciplinas, além do distanciamento entre am- 
bos e as demandas do mercado de trabalho. Finalmente, cabe destacar a defasagem entre a pesquisa institucionalizada e as necessidades de conhecimento por parte do setor produtivo, ou melhor, das organizações onde vão atuar profissionalmente os egressos das nossas escolas de comunicação.

Questões desta natureza induzem a repensar criticamente as estratégias destinadas a articular a produção de conhecimentos comunicacionais com a formação de profissionais midiáticos, no marco da emergente sociedade da informação. Nesse sentido, vamos retomar os argumentos esboçados em outro contexto (MARQUES DE MELO, 2004, p. 42-45) na expectativa de que eles possam ajudar compreender os impasses remanescentes.

Enquanto objeto de estudo, a Comunicação tem sido alvo de interesse de inúmeras disciplinas científicas, que a refletem teoricamente e analisam empiricamente, a partir dos seus respectivos paradigmas. Mas enquanto campo acadêmico (MIÉGE, 1995), sua identidade tem se caracterizado pelo delineamento de fronteiras estabelecidas em função dos suportes tecnológicos (mídia) que asseguram a difusão dos bens simbólicos e do universo populacional (comunidades / coletividades) a que se destinam.

Assim sendo, trata-se de um campo delimitado por duas variáveis:

1) A indústria midiática (organizações manufatureiras ou distribuidoras de cultura: jornal, livro, revista, rádio, televisão, cinema, vídeo, disco e congêneres, além dos instrumentos telemáticos em processo de configuração);

2) Os serviços midiáticos (empresas terciárias, dedicadas ao planejamento, produção e avaliação de mensagens, dados e in- 
formações, a serem difundidos pela mídia ou a ela concernentes - anúncios, campanhas, pesquisas, divertimentos etc.).

A principal fronteira é a que decorre dos limites entre dois segmentos.

De um lado, os atos de comunicação interpessoal (tradicionalmente objetos de estudos das ciências da linguagem ou das ciências do comportamento) e os atos de comunicação grupal (geralmente privilegiados pelas ciências da educação ou pelas ciências da administração).

De outro lado, os atos de comunicação comunitária (circunscritos a organizações complexas ou a espaços geograficamente contíguos, cuja abrangência pressupõe o uso de suportes tecnológicos de alcance reduzido) e os atos de comunicação pública (mediados por tecnologias de largo alcance e disponíveis a todos os membros da coletividade abrangidos pelo raio de audiência do canal). Pensava-se que estes últimos eram processos historicamente sem retro-alimentação. Contudo, hoje as inovações tecnológicas restauram a interatividade, possibilitando o diálogo imediato, mas nem sempre instantâneo, entre emissor e receptor.

O campo acadêmico da Comunicação Social corresponde a esse segundo núcleo, incluindo os atos de comunicação comunitária (comunicação organizacional, comunicação corporativa, comunicação institucional) e os atos de comunicação pública (comunicação massiva, comunicação mercadológica, cibercomunicação).

Trata-se de um campo vocacionado para a interdisciplinaridade, na medida em que seus objetos específicos são produtos cujo conteúdo está enraizado no território das demais disciplinas que constituem o universo científico. Além disso, os bens culturais 
que fluem através dos suportes midiáticos penetram no tecido social, constituindo estímulos para observações empíricas das ciências da sociedade. Tais conhecimentos servem como fonte permanente de retroalimentação dos processos produtivos no âmbito das indústrias midiáticas.

Nesse sentido, as ciências sociais representam fontes de conhecimento básico, das quais, enquanto produtores de conhecimentos aplicados, os midiólogos não podem prescindir.

A Comunicação Social tem, assim, um perfil multifacético, englobando as diferentes profissões que gravitam em torno das indústrias e serviços midiáticos. No quadro atual da sociedade brasileira estão plenamente configurados, em decorrência de regulamentação legal (SANTOS, 1995), quatro núcleos profissionais:

- Jornalismo

- Publicidade e Propaganda

- Relações Públicas

- Radialismo e Teledifusão

Conquistaram legitimação universitária, mas não alcançaram ainda status corporativo, três núcleos profissionais:

- Cinematografia

- Videoplastia

- Editoração

Existem, contudo, espaços atomizados de atuação profissional, não estruturados corporativamente, nem reconhecidos pela academia, embora demandados crescentemente pelas indústrias/serviços midiáticos:

- Entretenimento massivo 
- Teleducação

- Divulgação científica

- Comunicação cultural

- Comunicação organizacional

- Comunicação educativa

- Informação digital

- Pesquisa midiática

Trata-se de um conjunto de nichos profissionais a serem contemplados pelos currículos dos cursos de comunicação, naturalmente de acordo com a vocação de cada universidade, em consonância com as demandas do seu entorno comunitário.

\section{Diretrizes curriculares}

O que ensinar aos jovens que se matriculam nos cursos de comunicação? Ou melhor: como estruturar o currículo?

A formação dos profissionais da comunicação social pressupõe três blocos cognitivos a serem dinamicamente articulados:

1. Os conceitos comunicacionais que demarcam a identidade do campo acadêmico (embasados na "teoria da comunicação de massas" e na "estrutura dos sistemas midiáticos (indústrias/serviços)") e dos respectivos segmentos ocupacionais (construídos historicamente pelas corporações e renovados pelas evidências empíricas sistematizadas pela universidade, bem como pelas agências de pesquisa em funcionamento no interior das indústrias midiáticas ou das prestadoras de serviços).

2. Os processos midiáticos que configuram a produção, difusão e avaliação dos bens culturais correspondentes a cada 
segmento ocupacional, inclusive as rotinas profissionais, as linguagens, tecnologias, os preceitos legais, os métodos de planejamento e gestão. Mas também os seus instrumentos de retroalimentação, no sentido de manter plena sintonia entre as expectativas do mercado consumidor e as estratégias dos produtores culturais e dos patrocinadores.

3. Os conteúdos culturais que dão sentido às mensagens implícitas nos bens simbólicos construídos e/ou difundidos pelas indústrias/serviços midiáticos. Trata-se do domínio de conhecimentos enciclopédicos (visão geral da sociedade e dos seus pilares estruturais: história, política, economia, cultura, relações sociais) ou especializados (disponíveis no estoque cognitivo das ciências e das artes).

As três dimensões devem compor necessariamente a grade curricular dos cursos de comunicação social, sendo recomendável que a sua estrutura resulte de um diálogo permanente entre a universidade, as indústrias/serviços midiáticos e as corporações profissionais.

\section{Estratégias pedagógicas}

Em se tratando de campo profissionalizante, fincado no segmento das ciências sociais aplicadas, a implementação do currículo dos cursos de comunicação deve considerar as seguintes variáveis:

1. Sintonia entre os processos didáticos e a natureza de cada curso. Nesse sentido é recomendável a adoção de estratégias pedagógicas aglutinadoras dos três núcleos cognitivos, evitando-se a atomização das unidades de ensino e a justaposição dos conceitos, processos e conteúdos. Trata-se de amalgamar as 
partes em função de projetos laboratoriais, que possam simular ou reproduzir atos de comunicação, ensejando uma percepção integral da dinâmica produtiva.

2. Disponibilidade de laboratórios e equipamentos compatíveis com a natureza de cada segmento profissional. Garantir a sua existência significa evitar o retorno às situações vividas nos tempos pioneiros desse campo acadêmico, quando predominava o ensino verboso e livresco, tornando abstrata a aprendizagem. Para evitar o reducionismo didático ao âmbito dos laboratórios, estimulando produtivismo estéril, é desejável uma interação crítica entre produção e reflexão. Nesse sentido é que a pesquisa pode ser introduzida como instrumento pedagógico dinamizador, avaliando os processos de produção e gerando insumos para novos experimentos e trabalhos de campo.

3. O entorno local/regional em que os cursos estão situados deve necessariamente ser o ponto de partida para a organização da grade curricular. Afinal de contas é nas indústrias/serviços da cidade/região que os novos profissionais buscarão o primeiro emprego. Todavia, não se deve esquecer que os processos comunicacionais estão sendo submetidos a constante pressão nacionalizadora/mundializadora. Isso se reflete nitidamente nas rotinas produtivas. Daí a preocupação constante da equipe docente em manter-se sintonizada com as tendências nacionais/globais, desprovincianizando a formação profissional. Não esquecer que é legítima a aspiração dos jovens profissionais no sentido de galgar postos de trabalho nas empresas que encabeçam as redes midiáticas às quais estão vinculados os meios locais/regionais.

4. Em se tratando de um universo ocupacional em acelerado processo de mutação, como decorrência das inovações tecnológicas, das mudanças econômicas e das transformações 
culturais, não se justifica manter os cursos de graduação com a longa duração que hoje possuem. Experiências testadas em outros países demonstram que os ofícios midiáticos podem ser ensinados/aprendidos na universidade em regime de curta duração, dependendo evidentemente da bagagem cognitiva de cada aluno. Muitos estudantes que se inscrevem nos cursos de comunicação são originários de outras carreiras, carregando, portanto, um capital cultural que deve ser potencializado. Ao invés de condená-los a freqüentar disciplinas cujo conhecimento eles já adquiriram ou que não correspondem ao seu universo de expectativas para o exercício profissional, seria preferível dar-lhes a oportunidade de avaliação formal e, se considerados aptos, reduzir-lhes as exigências conteudísticas.

\section{Novos desafios}

Finalmente, é imprescindível que as universidades tenham sensibilidade para acolher as profissões emergentes neste campo acadêmico. Da mesma forma, justifica-se desativar ou transformar aquelas cujas demandas ocupacionais que encolheram ou se reduziram. Há casos em que é possível suprimir o curso, mantendo interesse pela profissão com um programa de pesquisas. Trata-se, em verdade, de preservar o diálogo entre as instituições acadêmicas e as comunidades a que servem e das quais recebem os subsídios para manter-se.

Vivemos uma conjuntura marcada pela ascensão da "sociedade da informação" como decorrência da expansão das novas tecnologias de reprodução simbólica. A ela correspondem várias profissões ainda não plenamente configuradas. Trata-se de mutações profissionais resultantes da fusão entre as indústri- 
as/serviços midiáticos e a telemática, bem como de novas demandas para midiastas e midiólogos com perfil globalizante.

A rapidez com que se processam hoje as mudanças no âmbito da mídia e das tecnologias que lhe dão suporte exige constante atualização dos currículos, das estratégias de ensino/aprendizagem e naturalmente a reciclagem do corpo docente.

Cabe aos dirigentes dos cursos de comunicação descobrir as evidências desses fenômenos e dar-lhes resposta imediata. Cabe ao professorado contribuir criticamente para implementar as mudanças e dar-lhes sentido convergente com a preservação das identidades locais/regionais. Cabe, finalmente, aos estudantes ocupar a vanguarda do sistema, atuando como agentes de inovação e como mediadores entre as instituições universitárias e as legítimas aspirações da sociedade.

\section{Notas}

${ }^{1}$ Conferência proferida na sessão de abertura do IV Encontro de Escolas de Comunicação do Estado de Pernambuco, promovido pelo Forum Pernambucano de Professores de Comunicação, em parceria com as Faculdades Integradas Barros Melo, na cidade de Olinda (PE), dia 18 de outubro de 2005.

\section{Referências}

ALBA, Gabriel; BUENAVENTURA, Juan Guillermo. Facultades de Comunicación: en el ojo del huracán, Signo y Pensamiento (31): 11-24, Bogota: Pontificia Universidad Javeriana, 1997.

AMARAL VIEIRA, R. A. A formação básica de um comunicador social voltado para a realidade brasileira, In: AMARAL VIEIRA, ed. - Comunicação de Massa: o impasse brasileiro. Rio de Janeiro: Forense Universitária, 1978. p. 261-286

BALLE, Francis. Médias et Societés. 8 ed. Paris: Montchrestien, 1997. 
BENITO, Angel. Fundamentos de Teoría General de la Información. Madrid: Pirámide, 1982.

BORDIEU, Pierre. O campo científico, In: ORTIZ, Renato, org. - Pierre Bordieu - Sociologia. São Paulo: Ática, 1983. p. 122-155

FRANÇA, Fábio \& FREITAS, Sidinéia Gomes. Manual da qualidade em projetos de comunicação. São Paulo: Pioneira, 1997.

FUENTES NAVARRO, Raul. Diseño curricular para las escuelas de comunicación. Mexico: Trillas, 1991.

FUENTES NAVARRO, Raul. Un campo cargado de futuro: el estudio de la comunicación en América Latina. Mexico: CONEICC, 1992.

GIANNOTTI, José Arthur. Universidade em ritmo de barbárie. São Paulo: Brasiliense, 1986.

HORKHEIMER, Max; ADORNO, Theodor W. Dialéctica del iluminismo. Buenos Aires: Sur, 1944. (ed. argentina - 1971)

JOBIM, Danton. Espírito do Jornalismo. Rio de Janeiro: São José, 1960.

KUNSCH, Margarida. Comunicação e Educação: caminhos cruzados. São Paulo: Loyola, 1986.

ABECOM / ECA-USP. O ensino de comunicação: análises, tendências e perspectivas, São Paulo: ABECOM / ECA-USP, 1991.

LAZAR, Judith. La Science de la Communication. Paris: Presses Universitaires de France, 1992.

LINS DA SILVA, Carlos Eduardo. A Política Educacional Brasileira e os Currículos dos Cursos de Comunicação, In: MARQUES DE MELO, LINS DA SILVA e FADUL - Ideologia e Poder no Ensino de Comunicação. São Paulo: Cortez \& Moraes/INTERCOM, 1979.

MARQUES DE MELO, José. Comunicação Social: Teoria e Pesquisa. Petrópolis: Vozes, 1970.

MARQUES DE MELO, José.Contribuições para uma Pedagogia da Comunicação. São Paulo: Paulinas, 1974.

MARQUES DE MELO, José. Subdesenvolvimento, urbanização e comunicação. 2ed. Petrópolis: Vozes, 1976.

MARQUES DE MELO, José. Comunicação e Modernidade. São Paulo: Loyola, 1991.

MARQUES DE MELO, José. Communication for a New World. São Paulo: ECAUSP, 1992.

MARQUES DE MELO, José. A constituição da comunidade acadêmica brasileira no campo das ciências da Comunicação. Santos: INTERCOM, 1997. 
MARQUES DE MELO, José. A esfinge midiática. São Paulo: Paulus, 2004.

MARQUES DE MELO; LINS DA SILVA; FADUL. Ideologia e Poder no Ensino de Comunicação. São Paulo: Cortez \& Moraes/INTERCOM, 1979.

MARQUES DE MELO, José. O Ensino de Comunicação e os Desafios da Modernidade. São Paulo: ECA-USP, 1991.

McQUAIL, Denis. Mass Communication Theory 4ed. London: Sage, 1994.

MIÉGE, Bernard. La pensée communicationelle. Grenoble: Presses Universitaires de Grenoble, 1995.

MUCCHIELLI, Alex. Les sciences de l'information et de la communication. Paris: Hachette, 1995.

NISKIER, Arnaldo. LDB - a nova lei da educação. Rio de Janeiro: Consultor, 1996.

NIXON, Raymond. Investigaciones sobre comunicación colectiva - rumbos y tendencias. Quito: CIESPAL, 1963.

PAQUALI, Orlando Alberto. O gueto da comunicação. Porto Alegre: Ed. Autor, 1987.

RIBEIRO, Darcy. O processo civilizatório. Rio de Janeiro: Civilização Brasileira, 1972.

RIZZINI, Carlos. O ensino de jornalismo. Rio de Janeiro: MEC, 1952.

SANTOS, Reinaldo. - Vade-Mécum da Comunicação. Rio de Janeiro: Destaque, 1995.

SCHWARZ, Laurent. Para salvar a universidade. São Paulo: TAQ/ EDUSP, 1984.

SOUZA, Pompeu. Faculdade de Comunicação de Massa, Cadernos de Jornalismo n. 2, p. 53-64. Rio de Janeiro: Jornal do Brasil, 1965.

TARGINO, Maria das Graças e MAGALHÃES, Laerte. Projetos Experimentais no Ensino de Comunicação: Teresina, Ed. Autores, 1993.

TEIXEIRA, Anísio. Ensino Superior no Brasil. Rio de Janeiro: FGV, 1989.

VOGT, Carlos. A solidez do sonho - universidade, ciência e desenvolvimento tecnológico. Campinas: Papirus, 1993.

WANDERLEY, Luiz Eduardo. O queé universidade. São Paulo: Brasiliense, 1983. 



\section{O resgate da memória}

E a construção da história da televisão no Brasil ${ }^{1}$

Sérgio Mattos

\section{Introdução}

Este trabalho tem como objetivo levantar questões sobre o resgate da memória da mídia televisão no Brasil. Os estudos acadêmicos sobre a televisão brasileira foram praticamente iniciados em fins da década de 60 do século passado e intensificados a partir da década de 1980, com a multiplicação dos cursos de pós-graduação e pela criação, na INTERCOM, do Grupo de Trabalho Televisão, atual Núcleo de Comunicação Audiovisual.

A abordagem procura identificar os pontos relevantes no levantamento histórico descritivo da televisão. Trata-se de uma reflexão sobre a importância da historiografia midiática no papel de construção do campo de comunicação, mais especifica- 
mente da televisão brasileira, devido à carência de postulados teóricos sólidos, analisando também as perspectivas e temáticas usadas a partir dos anos 70 do século passado na construção de uma memória da comunicação no Brasil. Destaca ainda a historiografia midiática como uma tarefa coletiva de longo prazo e tenta identificar aspectos essenciais que contribuam para o resgate da memória histórica da televisão em todas as regiões do país. Assim sendo, tenta-se identificar e sugerir temas, que precisam de estudos descritivos e de análises críticas que contribuam para o resgate da memória histórica da televisão em todas as regiões do país, além de propor ações a serem realizadas que nos permitam atingir os objetivos propostos visando ao resgate da memória da história de nossa televisão.

\section{Trabalho acadêmico - levantamento do conhe- cimento}

Apesar da televisão ter começado a operar no Brasil em setembro de 1950, este veículo só passou a ser objeto de estudo acadêmico a partir da década de 60 do século passado, quando os primeiros trabalhos, analisando o conteúdo de sua programação e seus efeitos sociais, começaram a ser produzidos. Vale destacar que o início de estudos sistemáticos dos veículos de comunicação de massa coincide com o período da criação de escolas de comunicação por todo o território nacional e sua intensificação ocorre mesmo a partir da década de 80 com a proliferação dos cursos de pós-graduação em comunicação.

Mesmo assim, até 1990, os estudos acadêmicos sobre a televisão produzidos no Brasil não ultrapassavam a marca dos cem títulos. Nos últimos 14 anos, no período compreendido entre 
1990 a 2004, uma quantidade enorme de estudos têm sido produzidos sem que tenhamos uma idéia exata do que está sendo feito por todo o país, o que nos leva a imaginar a necessidade de se construir um meio de resgatar e preservar estes estudos que compõem um dos alicerces do Campo da Comunicação no Brasil. Aliás, esta mesa, "A Memória e a Construção do Campo da Comunicação no Brasil”, promovida pela INTERCOM, tem este objetivo, o que por si só já é louvável, pois daqui surgirão, com certeza, idéias e definições para que isto seja transformado em realidade.

$\mathrm{Na}$ década de 70 do século passado, quando a televisão já havia se estabelecido no país como o mais ativo e importante veículo da indústria cultural, constata-se um considerável aumento na quantidade de pesquisas, descrevendo a estrutura organizacional da comunicação televisiva, analisando suas mensagens e efeitos no receptor, desvendando suas relações com os grupos dominantes e apresentando suas características de veículo capitalista e dependente (MATTOS, 2000 e 2003).

Examinando o material bibliográfico sobre a televisão pode-se constatar que a maioria dos trabalhos produzidos no Brasil apresenta análises e descrições sobre como este veículo se desenvolveu, influenciou ou foi utilizado pelas classes dominantes (MARQUES DE MELO, 1980). Apesar da produção bibliográfica brasileira sobre a televisão já ser bastante expressiva, constata-se, ainda, escassez de autores que se dediquem ao estudo de aspectos ainda não examinados ou que já o foram, mas de maneira superficial ou dirigida.

Quando a televisão completou 50 anos, no ano 2000, vários livros foram publicados, registrando o fato e relatos pessoais sobre a história de algumas emissoras em particular, resgatando depoimentos de profissionais, ou abordando as novas 
tecnologias como forças intervenientes no desenvolvimento da televisão e suas perspectivas futuras entre outros. À época, tentamos identificar, classificar e descrever a maior parte da bibliografia acadêmica e profissional disponível no país sobre a televisão brasileira (MATTOS, 2000), ressaltando que seria impossível para um pesquisador isoladamente identificar toda a produção de conhecimento, devido à grande quantidade de monografias, teses e dissertações de inúmeras faculdades de comunicação espalhadas por todo o território nacional e que não são amplamente divulgadas. Isto sem deixar de considerar também as edições de livros regionais que tratam a televisão como objeto principal de estudo, geralmente publicadas por editoras universitárias e limitadas tanto na tiragem como na distribuição do produto. Mesmo assim, com todas estas limitações, conseguimos classificar e registrar mais de 400 títulos de trabalhos, sendo que cerca de 300 foram produzidos ao longo da década de 90 do século passado.

Visando sistematizar os estudos identificados, classificamos e agrupamos os mesmos em cinco áreas temáticas gerais, um modelo que, com pequenos ajustes e acréscimos, acreditamos continuar ainda sendo válido. Para cada área temática identificamos sub-áreas de classificação, a fim de podermos registrar uma idéia mais ampla do conhecimento sobre a nossa televisão. As cinco áreas temáticas gerais são: 1- Aspectos Históricos da Televisão; 2 - Aspectos Sociais; 3 - Aspectos Políticos; 4 - Aspectos Econômicos; e, 5 - Informações Complementares. Os estudos correspondentes a cada um desses títulos foram agrupados de acordo com suas respectivas especificidades e/ou coincidência temática. Os trabalhos foram organizados em ordem cronológica, de maneira a permitir melhor identificação do conhecimento acumulado sobre cada aspecto estudado da 
televisão. Os estudos que tratam de mais de um aspecto do desenvolvimento deste veículo foram classificados de acordo com a maior ênfase dada por seus autores aos temas citados.

O grupo 1, a área dedicada aos Aspectos Históricos da Televisão ganhou duas sub-áreas: Aspectos Gerais e Aspectos Específicos. A primeira agrupando os estudos marcados por uma forte preocupação com a história do veículo, registrando seus fatos, datas e estatísticas mais significativas. A segunda, Aspectos Específicos, reúne os estudos de caráter histórico dedicado, por exemplo, a uma empresa ou rede televisiva de per si. Considerando que a maior parte de toda a produção acadêmica e profissional do país concentra-se nos Aspectos Sociais, o grupo 2, ganhou duas seções: a)- A televisão, sua mensagem, influência e efeitos sociais (produção e recepção das mensagens) e b)- Programas Televisivos, subdivido em Programas Infantis, Telejornalismo e Telenovela. Na primeira seção do grupo 2 estão os estudos que tratam da produção e recepção das mensagens televisivas, abordando sua influência e efeitos sociais. Na segunda, foram agrupados os trabalhos sobre programas de televisão de acordo com os temas mais freqüentes.

No Grupo 3, Aspectos Políticos, estão os trabalhos que tratam as relações da Televisão com o Estado: política de comunicação, ideologia e legislação. No grupo 4, Aspectos Econômicos, foram agrupados os estudos que analisaram aspectos do desenvolvimento econômico da televisão e sua interrelação com o sistema capitalista do país desde a década de setenta do século passado. Alguns dos estudos analisaram a estrutura empresarial e industrial da televisão e outros realizaram analises dos aspectos do seu desenvolvimento dentro do modelo capitalista dependente brasileiro. Este grupo ganhou duas sub-seções: 
a)- A Televisão e sua estrutura, b)- A televisão como veículo dependente.

No grupo 5, Informações Completares, foram classificados e fichados cronologicamente também os estudos sobre a televisão que, não tendo sido incluídos nos grandes grupos anteriores, foram analisados à luz dos seguintes temas ou sub-seções: a) Audiência e Televisão; b) Educação, cultura, satélite e televisão; c)Cinema, documentário, literatura, televisão e vídeo; d) Televisão regional; e) Produção independente; e f) TV a cabo.

\section{Modelo histórico - proposta de uma aborda- gem para análise}

Apesar de ser uma mídia relativamente nova, com pouco mais que 50 anos, a História da TV no Brasil permanece com várias lacunas a serem resgatadas e explicadas. Muito se tem pesquisado e publicado, mas precisamos levantar e conhecer ainda muitos outros aspectos e detalhes para melhor entendermos o processo de evolução deste veículo no Brasil.

Apesar de existir uma carência na área, pressupostos teóricometodológicos sólidos são indispensáveis para a construção da história da televisão brasileira como um dos mais importantes veículos do sistema de comunicação do país. Por isso, é indispensável que os estudos e análises para construir a história da TV sejam conduzidos sem dissociá-la do sistema brasileiro de comunicação do qual é parte. Ela precisa ser analisada como parte de um processo de mudanças e permanências das estruturas econômicas, políticas e sociais do país e não como parte isolada. A televisão, como outros veículos que compõem o sistema de comunicação, precisa ser, cada vez mais estudada, a 
partir de uma abordagem socioeconômica, política e cultural que considere também o meio de comunicação como um agente que intervem e ao mesmo tempo reflete o ambiente no qual está inserido.

No Brasil, as condições internas têm exercido sobre os veículos de massa influência muito mais forte do que os fatores externos. Aqui, os meios de comunicação, principalmente a televisão, e também a indústria publicitária têm refletido não apenas a forma particular de desenvolvimento dependente do país, mas também os interesses políticos de quem está no poder, como ocorreu durante o longo período da ditadura militar de 1964 a 1985, ou como ainda continua ocorrendo.

O caso do Brasil nos leva a repensar as suposições e hipóteses de inúmeras teorias que vêm estudando o desenvolvimento dos meios de comunicação, principalmente a televisão, nos países periféricos. Exatamente por isso acreditamos que estudos de caso podem ser de maior utilidade para se compreender o crescimento da mídia no Brasil do que muitas abordagens que tentam estudar a evolução da televisão brasileira a partir, e unicamente, de uma perspectiva global.

Defendemos também o ponto de vista de que, para estudar as causas e efeitos do processo global, precisamos construir uma teoria crítica e social da globalização que seja mais abrangente do que as teorias identificadas como sendo de direita ou de esquerda, responsáveis por enorme lista de estruturas teóricas (desenvolvimentistas, terceiro-mundistas e outras mais reformistas ou menos radicais) usadas para explicar o fluxo da informação, os veículos de comunicação, principalmente a televisão, e os processos de interação sociocultural entre as nações.

Por isso, qualquer estudo sobre a televisão deve ser feito sem negar, rejeitar ou ignorar modelos anteriores, uma vez que o 
mundo ainda está cheio de evidências que, em parte ou no todo, comprovam várias teorias. Os estudos que aplicam as teorias da globalização para explicar o que está ocorrendo com a televisão em determinado país, o Brasil, por exemplo, não podem deixar de considerar a realidade local em relação à realidade global, a regionalização versus a globalização. Precisamos, portanto, enfatizar e privilegiar a análise dos contextos para melhor compreensão do desenvolvimento da nossa televisão porque não vemos a comunicação e a tecnologia em si, quase como entronizadas, produzindo sentido e desconectadas do todo econômico, político, social e cultural de uma nação.

Da mesma forma que a política socioeconômica brasileira se desenvolveu dentro de uma mesma matriz, mas sempre oscilando de acordo com as tendências mundiais e ideológicas vigentes, o desenvolvimento da nossa televisão também sofreu a influência direta e indireta das mudanças do contexto. Contexto que apresenta não uma, mas várias realidades, devido à anomalia que é a nossa história contemporânea, que torna quase impossível a tarefa de se estabelecer critérios com os rigores da historiografia sob pena de apresentarmos resultados com distorções.

A história da televisão não é diferente da história contemporânea do rádio, jornal e publicidade, assim o que se deve procurar é entender como os fatores internos e externos, os contextos político, socioeconômico e cultural interferiram no desenvolvimento histórico de cada veículo que compõem o sistema de comunicação brasileiro.

Há mais de 20 anos, defendemos (MATTOS, 1982) que para estudarmos e compreendermos qualquer veículo de comunicação no Brasil, principalmente a televisão, precisamos construir uma estrutura de análise, com uma abordagem histórica, 
dos meios de comunicação que leve em consideração o contexto socioeconômico, político e cultural, pois só assim poderemos compreender, plenamente, a evolução do veículo e suas variações, no tempo e no espaço, devido às influências internas e externas. Só assim, poderemos perceber como a dinâmica social interfere, se reflete e se relaciona com a dinâmica do veículo e vice-versa. Assim sendo, a importância dos fatores intervenientes de cada período histórico se refletem e influenciam a história do veículo estudado.

Aqui cabem algumas perguntas: Qual a importância do resgate da memória da mídia TV no Brasil? Qual a importância da historiografia midiática no papel da construção do campo da televisão? Quais os pontos que são relevantes no levantamento histórico descritivo da TV? Uma resposta pode estar baseada em um velho jargão: conhecer a história é fundamental para que possamos entender o presente e ao mesmo tempo podermos projetar o futuro.

Todos os estudos de aspectos particulares da televisão devem ser considerados como elementos interdependentes de um contexto global. Cada estudo realizado sobre a televisão deve levar em consideração, seja qual for, que o aspecto ou recorte a ser feito continua sendo parte de um todo, recebendo influência do meio, mas também atuando sobre ele, modificando a realidade. Devemos reconhecer que a televisão é uma mídia interdependente. Precisamos estar conscientes da televisão como unidade em si e da interrelação dela com o meio no qual está inserida, sofrendo influência e influenciando a realidade do contexto socioeconômico político e cultural. 


\section{Questões a responder}

Nesta seção pretendemos instigar o debate sobre o tema, levantando algumas questões sobre a mídia televisão, que ainda carece de investigação, ou de novas pesquisas que venham esclarecer e contribuir para o resgate da memória deste veículo de massa. São apenas idéias levantadas que se consideradas, refletidas e analisadas, em algum projeto experimental de graduação, dissertação ou tese podem contribuir um pouco mais para a construção do conhecimento da história da televisão brasileira. O levantamento de aspectos gerais e específicos da história da TV é indispensável também para conhecermos e resgatarmos os grandes nomes da TV brasileira ainda desconhecidos.

Na década de 50, quando a televisão foi implantada no país, os jornais eram responsáveis pela publicação diária de 5,7 milhões de exemplares. A população era de 52 milhões pessoas. Passados 54 anos da implantação da TV, com uma população superior a 170 milhões, os jornais brasileiros não ultrapassam a tiragem dos 8 milhões de exemplares por dia. Inúmeros estudos têm sido produzidos sobre esta realidade e vários agentes já foram identificados como possíveis responsáveis diretos e indiretos pela baixa tiragem de exemplares. Mas, sem afirmar que inexiste, desconheço qualquer estudo feito que tenha analisado especificamente a influência da televisão neste processo como um todo no Brasil e não isoladamente em alguma cidade ou Estado.

Considerando que o avanço tecnológico está apontando para uma convergência das mídias, deveremos também procurar constatar se a Internet é ou não responsável pela queda acentuada da venda avulsa dos jornais nos últimos cinco anos. Qual a influência direta da televisão na diminuição do índice de leitura de jornais, livros e revistas no país? É pertinente observar e estudar 
aspectos como a chegada da TV paga (cabo) na diminuição das tiragens dos jornais. Como estabelecer critérios e variantes que possam detectar esta influência negativa nos jornais?

Muito se tem falado e escrito do resultado danoso da Censura no desenvolvimento da comunicação brasileira e em especial sobre os efeitos dela na televisão, mas poucos são os estudos feitos para mapear realmente quais foram os danos sofridos. Como a censura foi exercida, o que ela impediu de acontecer e como limitou o desenvolvimento da TV? Qual foi a real interferência da censura na limitação do desenvolvimento da criatividade e do desenvolvimento da produção local da Televisão?

Permanecem ainda desconhecidos inúmeros aspectos do papel danoso e das conseqüências da censura exercida nas emissoras e redes de televisão durante os governos militares. Conhecemos casos isolados e de caráter geral nas grandes emissoras. Desconhecemos, entretanto, as experiências e casos regionais vividos por cada emissora, salvo raras exceções. Como cada emissora regional se comportou no período da censura e como resistiu às pressões da censura? Só saberemos quando começarmos a investigar e resgatar a história de cada emissora, colhendo depoimentos de profissionais e procurando descrever cada história, considerando-se o contexto socioeconômico político e cultural de cada região.

Sabe-se que, entre 1972 e 1975, a censura federal enviou mais de 300 comunicados aos grandes jornais, proibindo notícias e coberturas. E na Televisão, como era exercida esta censura? Precisamos conhecer e resgatar mais detalhes sobre a televisão e sua relação com censura tal como já começa a ser feito no jornalismo impresso. Considerando que na época da ditadura, o Estado de S. Paulo, Jornal da Tarde, Jornal do Brasil e a Veja, entre outros, encontravam meios para alertar seus leitores de 
que estavam sob censura, por meio de publicações de como cultivar rosas, receitas de bolo ou versos de Camões inseridos nos espaços censurados, precisamos ainda saber o que foi feito ou se é que foi feito alguma coisa semelhante na TV? O que foi feito no telejornalismo e pelos jornalistas atuantes para denunciar que o noticiário estava censurado. Será que não houve nenhuma tentativa de se fazer isto na TV?

O jornalista Vladimir Herzog é símbolo de luta pela liberdade dos direitos humanos e da liberdade de imprensa. Quantos, como ele, existem na história da TV brasileira e que permanecem incógnitos porque ninguém ainda escreveu a verdadeira história de cada emissora, que é a célula de todo o sistema de televisão nacional. Precisamos conhecer tudo para entendermos como certos elementos e variáveis têm poderes diferenciados em cada região do país e como estas variáveis funcionam e influenciam diferentemente em cada região.

Quem são os jornalistas ou profissionais de televisão que exerceram um papel de resistência aos abusos da censura ao longo da existência da TV? Precisamos identificá-los e colher depoimentos dos profissionais que sofreram ações oficiais por resistirem aos efeitos do Golpe de 64. Quais os profissionais regionais que se destacaram como verdadeiros baluartes da defesa da liberdade de imprensa?

No que diz respeito aos aspectos econômicos e suas influências no desenvolvimento da televisão, carecemos ainda de muitos esclarecimentos, como por exemplo: Qual a influência das agências de publicidade e do setor publicitário na programação e conteúdo da televisão, inclusive as regionais? Os estudos iniciais constataram uma influência direta no conteúdo, na forma e até mesmo na adoção do nome dos patrocinadores como sendo o nome dos programas ("Repórter Esso", "Reportagem 
Ducal”, “Telejornal Pirelli”, “Teatrinho Trol”, etc). E hoje em dia, como se dá esta influência e como são feitos os acordos de patrocínio de programas? Como se dá a interferência do patrocinador e das agências de publicidade no processo de produção? $O$ merchandising também carece de estudos: qual a sua influência nos hábitos de consumo e dos valores culturais por meio da televisão? Como é exercida a censura econômica na televisão brasileira? Qual o papel das exportações da TV Brasileira? A Globo, a exemplo de outras, continua exportando seus programas para mais de 80 países, mas nenhum estudo foi realizado ainda sobre o impacto desses programas na cultura de outros povos. A influência da televisão na música brasileira e no aumento de vendas de CDs também não foi estudado ainda, mas, para citar um dado recente, só o CD da trilha sonora da novela "Mulheres Apaixonadas" vendeu 1,5 milhão de cópias.

Dentro da categoria dos aspectos sociais, muitas inferências têm sido levantadas sobre a influência da televisão, mas precisamos confirmá-las. Precisamos resgatar e registrar a força da televisão como transformadora de valores e costumes, reforçando mudanças e estimulando o consumo da sociedade. Qual a evolução de cada cidade, ou região brasileira, a partir da chegada de televisão? O que mudou nas cidades brasileiras depois do exemplo da influência da TV em Ibitinga, cidade do interior paulista, registrada por Luís Milanesi (1978) em "O Paraíso via Embratel"? Como a televisão contribuiu para mudar o quadro referencial dos habitantes das cidades? Com a chegada da televisão nas cidades houve a constatação ou não do crescimento demográfico? A relação direta e indireta da televisão sobre os índices demográficos brasileiros é uma questão que também permanece obscura e ainda não foi estudada com seriedade e de forma interdisciplinar. O papel da televisão na 
mudança do comportamento e hábitos sexuais dos brasileiros também carece de análises. A televisão como fator de desagregação familiar pode também ser um campo rico de investigações interdisciplinares, envolvendo comportamento, discurso infanto-juvenil, educação, produção e recepção das mensagens entre outros.

O telejornalismo é um aspecto específico que precisa ser mais estudado. Qual a influência do newjournalism no telejornalismo? Qual o papel e a contribuição específica do telejornalismo na formação de opinião e conscientização da população brasileira? Qual o papel do telejornalismo no processo de conscientização política e sua interferência na política propriamente dita? Estudos precisam também ser conduzidos, analisando com profundidade o processo de banalização e dramatização dos programas jornalísticos, pois a notícia está virando ou já virou show.

\section{O que fazer}

Nesta seção pretendemos sugerir algumas ações que precisam ser colocadas em prática, nas Escolas de Comunicação Social, pelos pesquisadores, professores e entidades que têm um compromisso com a área da Comunicação, a exemplo da INTERCOM, visando contribuir para o resgate da memória e a construção mais completa da história da televisão brasileira. Muito se tem escrito e produzido, mas, apesar da tecnologia moderna e da Internet, continuamos sem saber o que já foi produzido e o que se está produzindo no país. A exemplo do que José Marques de Melo fez, implantando a Rede Alfredo de Carvalho, com o objetivo de resgatar a história do jornalismo e da mídia em geral, precisamos também criar uma Rede 
de Informação sobre a Televisão e que só se dedique a este veículo de massa, independente dos núcleos e GTs já existentes na Intercom, Compós, Rede Alfredo de Carvalho, entre outros, destinados aos estudos desta mídia. O que estamos propondo é a constituição de um Instituto Nacional que congregue profissionais, pesquisadores e professores da área de televisão com o objetivo de se dedicar mais direta e especificamente ao resgate da história e ao estudo da influência deste veículo no país como um todo.

Considerando que, ao longo de sua existência no país, inúmeras emissoras foram destruídas pelo fogo em várias regiões, considerando que com os avanços da tecnologia de gravação perdemos muita coisa (videoteipes originais), precisamos resgatar a memória das emissoras regionais também, entrevistando os profissionais que trabalharam ou estiveram envolvidos com emissoras de TV. Precisamos resgatar a história das emissoras regionais a partir dos depoimentos destes homens. A seguir listamos uma série de sugestões sobre o que precisamos fazer:

- Fazer um inventário sobre o que já foi produzido sobre a nossa televisão, criando um Banco de Dados.

- Levantar e disponibilizar, On Line, o acervo bibliográfico sobre a televisão brasileira, incluindo todas as dissertações de mestrado, teses de doutorado e de monografias de conclusão de cursos de especialização em nível de pós-graduação. Para tanto, as Escolas de Comunicação devem criar sítios específicos na WEB para disponibilizar a produção que vem sendo feita. Ter acesso e conhecimento da existência de toda a produção nacional é importante para que possamos resgatar a memória histórica da televisão brasileira em todos os seus detalhes. Regionalmente, os grupos de pesquisa devem mapear 
todos os principais jornais e revistas do país, classificando, recortando e analisando notícias e comentários sobre a televisão, seus programas e pessoas neles envolvidos.

- Precisamos identificar a influência das Escolas de Comunicação na televisão, não só como formadora de mão-de-obra especializada, mas como crítica do processo, produzindo estudos e análises sobre sua produção.

- Avaliar o desenvolvimento da televisão, tendências seguidas e opções adotadas nas diversas conjunturas históricas.

- Acompanhar e resgatar a história da TV e de seus agentes, como um dos mais influentes veículos da mídia nacional, pois isto é fundamental para uma análise geral do Estado e do País.

- Observar e comparar a mídia Televisão dentro do contexto histórico, socioeconômico, político e cultural do país, levando em consideração a sua interdependência.

- Identificar e traçar os perfis dos profissionais da área com suas respectivas contribuições. O resgate de nomes e instituições televisivas em todo o país é de fundamental importância para se entender a televisão brasileira atual e projetá-la para o futuro. Não podemos considerar apenas os avanços tecnológicos e as tendências de convergência de mídia.

- Para resgatar a história da televisão precisamos trabalhar as relações deste veículo com todos os fatores intervenientes no processo.

- Estudar e acompanhar a implantação das novas tecnologias que vão interferir no desempenho da mídia televisão a exemplo da TV Digital. Isto porque, em março de 2005, o grupo Gestor que coordena os estudos sobre o Sistema Brasileiro de TV Digital (SBTDV) deve apresentar ao governo não um protótipo da TV Digital brasileira funcionando, mas sim um mo- 
delo de referência que indicará o que poderá ser de fato implantado no país.

- Acompanhar, com estudos e análises, o impacto que o MOBILE TV exercerá sobre o conteúdo da televisão, podendo mudar todo o conceito que temos hoje do uso do meio televisão pela população e pelos setores econômicos. Canais de TV brasileiro já estão negociando para poder transmitir sua programação via celular (telinha). A VIVO lançou em março de 2004 um serviço em que o assinante pode acessar notícias e programas de entretenimento da TV Terra. Também já é possível baixar imagens do trânsito de São Paulo e baixar trailers de longas-metragens. O próximo passo é transmitir conteúdos das emissoras Abertas de TV. A TIM já está prometendo disponibilizar a programação da TV aberta. O usuário pagará para acessar esses conteúdos. Diante de avanços tecnológicos como este, que exercerão forte impacto sobre a mídia, estamos dedicando mais atenção à tecnologia em si do que a forma como e qual o conteúdo que será transmitido por meio dela.

Além, de um inventário da história da TV Brasileira precisamos contextualizá-lo para melhor entender o que aconteceu e o que está acontecendo.

\section{Conclusões}

Após o exposto, a título de conclusão, só nos cabe conclamar todos os pesquisadores da área, professores, estudantes de comunicação e as instituições vinculadas ao setor, como Faculdades de Comunicação e entidades como a própria INTERCOM, - Sociedade Brasileira de Estudos interdisciplinares da Comunicação, ABECOM - Associação Brasileira de Escolas de Co- 
municação, e a Associação Nacional dos Programas de Pós-Graduação em Comunicação e outros a participar desta tarefa de resgate da memória visando à construção da história da televisão no Brasil.

Muito tem sido escrito sobre a televisão brasileira, muitos recortes de sua história já são conhecidos. Precisamos agora conectá-los e inseri-los no contexto histórico para entendermos o que está acontecendo hoje. Enfim, precisamos encontrar uma nova maneira de entender a televisão como um dos veículos para a compreensão da realidade.

\section{Notas}

${ }^{1}$ Texto apresentado ao XXVII Ciclo de Estudos Interdisciplinares da Comunicação na mesa redonda "A memória e a construção do campo ca comunicação no Brasil”, durante o XXVII Congresso Brasileiro de Ciências da Comunicação realizado de 30 de agosto a 3 de setembro de 2004, em Porto Alegre, Rio Grande do Sul.

\section{Referências}

MARQUES DE MELO, José de. Comunicação e classes subalternas. São Paulo: Cortez, 1980.

MATTOS, Sérgio. Domestic and foreign advertising in television and mass media growth: a case study of Brazil. Austin, Texas: The University of Texas, 1982 (Tese de Doutorado).

MATTOS, Sérgio. A televisão no Brasil: 50 anos de historia (1950-2000). Salvador: Editora PAS - Edições Ianamá, 2000.

MATTOS, Sérgio. História da Televisão Brasileira: uma visão econômica, social e política. Petrópolis: Editora Vozes, 2002.

MILANESI, Luís. O paraíso via Embratel. Rio de Janeiro(Footnotes) 


\section{A construção dos âncoras}

Nos telejornais nacionais da Globo

Valério Cruz Brittos

Paloma Rühee

No telejornalismo, sempre coube à figura do âncora o papel de interligar os acontecimentos dentro do telejornal e buscar a interação do conteúdo noticioso com seu público. A forma carismática com que eles procuram transmitir as notícias contagia tanto o público, que não são raras as circunstâncias em que o telespectador, através do aparelho televisor, responde às interações propostas pelos interlocutores. Por estar na vitrine do telejornal, compete a ele a função de abrir as portas para esse diálogo entre mídia e receptor.

A partir do entendimento do papel do âncora é possível compreender qual a mensagem que a emissora de TV está tentando passar, na medida em que o substrato ultrapassa os limites da simples informação. É possível observar quais os interesses que estão por trás desta figura, que fun- 
ciona como porta voz da empresa. Essas observações às vezes passam despercebidas ao olhar do telespectador, que nem se dá conta de todo o jogo de interesses que há por trás deste discurso, sendo capturado facilmente pelas idéias que estão lhe comunicando.

Este artigo analisa a construção do âncora pela maior rede de televisão brasileira, a Globo, tomando como base seus quatro telejornais nacionais: Bom Dia Brasil, Jornal Hoje, Jornal Nacional e Jornal da Globo. Através da pesquisa é observado como a emissora, apesar de transmitir um padrão geral, constrói seus apresentadores diferentemente, conforme os horários de exibição dos seus programas jornalísticos. Procurando entender melhor essa figura, tão comum ao dia-dia de todo público que assiste à televisão, este trabalho faz uma análise dos métodos que a Globo se utiliza para construir os interlocutores destas atrações.

Visando avaliar a maneira como os discursos dos apresentadores da Rede Globo são criados para dialogar e interagir com seu público, são analisados certos quesitos. Entre estes estão, por exemplo, o grau de informalidade de cada telejornal e a ligação deste com o horário de veiculação e tipo; a maneira dos âncoras dialogarem e se expressarem entre si; o uso de tipos de linguagem corporal e oral; e se há no discurso falas que buscam uma interação entre o destinador e o destinatário (para criar, desta maneira, ilusão de diálogo).

\section{Processos de construção}

Focando os programas jornalísticos e seus estilos de apresentação, pode-se dizer que as palavras utilizadas pelos interlocutores e o tom empregado na narração de uma notícia são fatos 
marcantes na composição de um bom âncora ${ }^{1}$ e de um telejornal de qualidade. Conforme Squirra, um dos predicados fundamentais do moderno âncora "é que tenha uma boa voz e dicção clara e eficiente” (1993, p. 16). O som é um dos principais pontos observados pelo telespectador, sendo através dele que se dão os primeiros contatos entre as duas partes.

O conjunto envolvendo postura, boa aparência e desenvoltura do apresentador traz sua contribuição, mas a linguagem e a forma de narrativa utilizada terão uma função especial na dinâmica de atrair a atenção de quem está ouvindo e assistindo ao programa. Por isso que é preciso causar boa impressão desde o princípio, para manter o telespectador atento ao telejornal.

Embora o âncora esteja lendo um texto previamente escrito, a linguagem utilizada na composição deste discurso não é de caráter genuinamente gramatical, pois, como o intuito é informar e estabelecer uma conexão com o destinatário, ele precisa fazer uso de outras linguagens. Enquanto a notícia necessita ser escrita em tom de diálogo, utilizando palavras do dia-a-dia das pessoas, as frases precisam ser ditas na ordem direta, evitando falas difíceis, que irão prejudicar o entendimento. A televisão precisa que a linguagem não seja tão elaborada quanto num jornal, porque fica difícil para o telespectador rever a notícia depois, caso não a tenha entendido perfeitamente, como acontece com uma matéria publicada num veículo impresso. É preciso que ela passe o recado imediato, sendo compreendida tão logo recebida.

Conforme Sodré (1989, p. 56-57), o vídeo televisivo dirige-se ao público simulando um contato direto e pessoal. Diante disso é que a função lingüística de contato ou linguagem fática, terminologia criada por Jakobson (1968, p. 126), é tão usada por esse meio, que visa com ela manter ou sustentar a comu- 
nicação entre falante e ouvinte. $\mathrm{O}$ discurso dos telejornais acaba sendo construído em cima dessa linguagem, para buscar uma aproximação entre o enunciador e receptor. O que Muniz Sodré destaca a respeito de tal linguagem é completado por Fausto Neto (1995, p. 41):

O mecanismo básico com que tais dispositivos buscam se manter vinculados com o campo da recepção se constitui, por exemplo, em fazer funcionar a função fática lembrada por Jakobson. Através dela, não só se institui a relação entre ofertas e recepção dos discursos, mas, também, se estrutura a instância na qual o enunciador se dirige especificamente à recepção, pedindo-lhe atenção, ordenando-a sobre determinados aspectos, interpelando-a e, finalmente, buscando, dessa forma, o estabelecimento de interações com outras dimensões heterogêneas de discurso.

Frente a essas observações pode-se entender o porquê de muitos âncoras, ao iniciarem a apresentação de um telejornal, cumprimentarem o seu receptor com um "olá", ao invés, do formal bom dia ou bom noite. O "olá" estabelece um contato entre falante e ouvinte, cria um vínculo, algum grau de intimidade entre ambos. Por intermédio dessa empatia criada entre apresentador e receptor, o programa jornalístico vai ganhando credibilidade e atraindo maior público, identificado com o enunciador e com a programação.

Construída baseada no discurso familiar da conversa cara-acara e dos princípios morais, a linguagem descontraída usada pelos telejornais também têm este poder de persuasão. Um discurso bem aplicado, associado ao fato dele estar presente quase que diariamente no cotidiano do receptor, permite ao âncora interferir de tal forma na vida de quem o assiste que, aos poucos, o telespectador vai se sentindo familiarizando com sua presença. ${ }^{2}$ 
Não obstante saber que o diálogo com o apresentador é apenas ficção, uma vez que só uma das partes ouve, o fato dele estar sempre presente no seu cotidiano faz com que o receptor responda às interlocuções do âncora por diversas vezes, não sendo raros aqueles que questionam, discutem e comentam com o televisor, como se estivessem falando diretamente com a pessoa apresentada no monitor.

De um apresentador é esperado não só que saiba falar, mas também que domine a postura diante das câmeras. A questão da boa apresentação é tão fundamental nos telejornais que, nas emissoras, as roupas, a maquiagem e o corte de cabelo do âncora não são decididos por ele próprio. Na Rede Globo, por exemplo, há uma equipe formada por 20 profissionais, que assessoram toda a Central de Telejornalismo.

Naqueles telejornais que dispõem de mais de um âncora na sua apresentação, ou que recebem comentaristas, torna-se importante a interação entre os elementos em cena, para transmitir ao público corretamente a mensagem objetivada. Devido a isso, eles dialogam entre si, ou ao menos agem por alguns momentos como se tivessem o fazendo, passando ao público a impressão de que estejam realmente "dividindo a mesma bancada". Por menores que sejam esses detalhes, os mesmos "produzem um acabamento", se assim pode-se dizer, ao conteúdo transmitido.

Também a comunicabilidade fica mais intensa em função do tipo de enquadramento utilizado para captar a imagem do interlocutor. O close, conforme Sodré (op. cit., p. 66), é o mais usado no meio televisivo. Focando exclusivamente o âncora, o close permite que o receptor tenha de forma mais intensa a sensação de estar cara-a-cara com aquele que está lhe falando. 
Os apresentadores também precisam agregar fatores da linguagem corporal para instaurar com o telespectador uma situação de diálogo. Se quando duas ou mais pessoas conversam pessoalmente ficam constantemente movimentando braços, mãos, fazendo expressões faciais para dar maior sentido ao fato narrado, nos telejornais os âncoras têm que agir semelhantemente. Isso ocorre pelo fato de haver a necessidade do enunciador buscar esta relação de proximidade com o espectador, o que não ocorreria no caso de uma postura estática deste comunicador, o que ainda evidenciaria a leitura dos diálogos via teleprompter. Então, os fatores linguagem, gestos, sons e imagens resultarão no produto final da comunicação, para o que contribui a confiança despertada pelo apresentador no público.

A confiança dos telespectadores em um telejornal está intimamente ligada à credibilidade dada aos âncoras. Caso exista desconfiança sobre o conteúdo apresentado, pressupondo que haja omissão dos fatos ou inverdades, automaticamente haverá o descrédito do público quanto ao programa e, conseqüentemente, a queda de audiência. No firmamento da credibilidade dos apresentadores da Globo, foram fundamentais os movimentos, adotados a partir de 1995, de substituir os locutores por jornalistas, na condução dos telejornais. De acordo com Barbosa e Ribeiro (2005, p. 205-223, 221), "mais do que uma alteração narrativa, trata-se, sobretudo, de uma mudança relacionada ao princípio da autoridade profissional". Como numa conversa cara-a-cara, a relação âncora-receptor também depende da confiança depositada em quem narra o fato, por parte de quem o consome. 


\section{Metodologia e análise}

Os estudos exclusivamente voltados ao conhecimento do fazer jornalismo vêm crescendo, não só no Brasil, desde o final do século XX, prometendo perspectivas de grande avanço no terceiro milênio. "O estudo do jornalismo constitui um campo com já longas tradições, embora alguns membros da comunidade jornalística teimem em ignorar ou desprezar esse 'corpo técnico' [...]" (TRAQUINA, 2001, p. 52). Nesse sentido, não há mais o que discutir acerca da legitimidade das pesquisas voltadas aos modos de fazer jornalismo e seu papel social.

Relativamente à amostragem utilizada nesta análise, selecionouse um total de 87 edições, sendo 19 do Bom Dia Brasil, 24 do Jornal Hoje, 24 do Jornal Nacional e 20 do Jornal da Globo. A escolha do período, 28 de março a 23 de abril de 2005, se deu de forma aleatória, em função de não interferir drasticamente na maneira que se dá a construção do apresentador pela emissora. Apresentado por Renata Vasconcellos e Renato Machado, o Bom Dia Brasil vai ao ar de segunda a sexta, das 7 h15 às 8 h05. ${ }^{3}$ O Jornal Hoje, por sua vez, ocorre de segunda a sábado, das $13 \mathrm{~h} 15$ às 13h45, com apresentação a Sandra Annenberg e Evaristo Costa. ${ }^{4} \mathrm{O}$ principal telejornal da emissora, o Jornal Nacional, é exibido de segunda a sábado, das 20h15 às 21h, sendo apresentado por Fátima Bernardes e William Bonner. ${ }^{5}$ Diferentemente dos outros telejornais da emissora, o Jornal da Globo, veiculado de segunda a sexta, tem horário de início oscilante, entre as $23 \mathrm{~h} 30$ e meia-noite. ${ }^{6}$ A apresentação ficou a cargo da jornalista Ana Paula Padrão, que era a âncora do programa durante o período analisado e hoje está no SBT. Atualmente o jornal é apresentado por William Waack e Christiane Pelajo. 
As imagens foram captadas de uma antena de UHF (ultra high frequency), sendo todas as edições gravadas em fitas de vídeo. Primeiramente procedeu-se a uma análise quantitativa, na qual se procurou verificar o tempo de fala dos apresentadores em cada programa, os enquadramentos usados para focá-los e a postura, bem como em quantas edições a apresentação do telejornal se deu com o âncora em pé e quantas se deu com ele sentado. Com estes dados quantitativos fez-se uma análise para verificar como essas observações se tornam relevantes na construção da imagem dos apresentadores.

Posteriormente, na análise qualitativa, observou-se a aparência, os gestos e expressões faciais usadas pelos apresentadores na hora de narrar um fato e o discurso em si, buscando, com isso, analisar de que forma esses pontos são construídos e qual a importância deles para o andamento do telejornal. Procurou-se observar as possíveis inserções de opinião, a forma na qual o texto telejornalístico foi escrito - se direta e simples, como as normas de redação tendem a consagrar. Foi focada ainda a utilização da informalidade, na intenção de aproximação do indivíduo televisivo com o telespectador.

Os dados indicam que o âncora tem um tempo considerável de fala, por ser o principal personagem de um telejornal, cuja função é dialogar com o público e introduzir os acontecimentos. Em média, nos quatro programas exibidos pela Rede Globo o tempo de fala para os interlocutores é o mesmo. O tempo que estes ocupam é de pouco mais de um quarto da duração total dos programas, como é possível observar no gráfico 1 . 


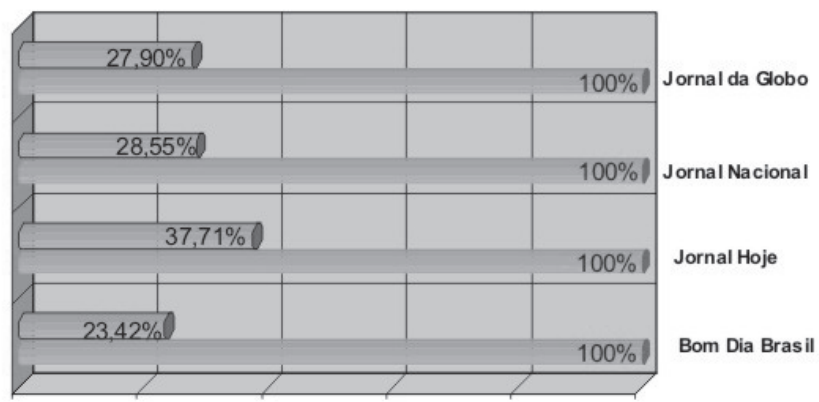

Tempo total do telejornal $\square$ Tempo de fala que o âncora ocupa no telejornal

\section{Gráfico 1. Tempo total de fala do âncora em cada telejornal}

Obs: análise de toda a amostragem.

Fonte: organização da pesquisa.

No Jornal Hoje os apresentadores dispõem de mais tempo de fala, o que pode ser explicado por contar com muitas notas cobertas - matérias as quais o âncora narra o fato enquanto as imagens vão sendo exibidas. O menor tempo para eles está no Bom Dia Brasil, onde jornalistas, situados em outras cidades, acrescem ao programa informações de várias partes do país. Estes entram ao vivo e chamam reportagens sobre os locais onde estão situados. A constatação de que os âncoras têm um tempo de fala consideravelmente grande era algo já previsível, pois são eles os responsáveis por cativar o telespectador.

Outra constatação possível é que talvez a primeira imagem que venha à mente do receptor é a de um jornalista sentado atrás de uma bancada narrando os fatos do dia. Realmente esta ainda é a forma mais tradicional de apresentação dos programas jornalísticos. Dos quatro telejornais da Globo analisados, três ainda utilizam esta formação. A exceção é o Bom Dia Brasil, que, além da bancada tradicional, ainda faz uso de um outro 
cenário, imitando uma sala de estar. A construção cenográfica diferenciada permite que o apresentador apareça, em uma ou outra vez, em pé ao dar uma notícia, ou também caminhando pelo espaço enquanto narra o fato. É interessante colocar também que o Jornal Nacional chegou a ser ancorado ao vivo de fora do estúdio, em específico no período dos atos fúnebres do Papa João Paulo II. Nesta circunstância, Willian Bonner fez a cobertura do acontecimento diretamente da cidade do Vaticano, em pé na Praça de São Pedro, o que acabou se diferenciando do padrão adotado pelo programa.

O plano de câmera utilizado junto ao âncora é fator relevante no nível de atenção do espectador. A investigação constatou que são usados praticamente três tipos de plano nos telejornais: o Primeiro Plano (PP) ou close, que mostra o apresentador do peito para cima; o Plano Médio (PM), que foca a pessoa da cintura para cima, ou do joelho para cima; e o Plano Geral (PG), que mostra os indivíduos e os cenários como um todo. $\mathrm{O}$ close tem destaque dentro deste segmento televisivo, pois o enquadramento aproximado do apresentador possibilita ao público melhor visualizar as expressões faciais do âncora. Isso acarreta a maior sensibilização por parte do público, que presencia as reações do interlocutor e acaba por assimilar de forma mais eficaz os fatos por ele transmitidos.

Por possuir um cenário maior que o dos outros quatro analisados, o Bom Dia Brasil utiliza o PG com mais freqüência. O Jornal Hoje é o noticioso que mais utiliza o PP, em 65,74\% das aparições dos âncoras. O Plano Médio praticamente não é usado, somente em algumas edições de sábado, onde há apenas um apresentador na bancada. 
Também no Jornal Nacional são freqüentes os enquadramentos em PM e PP. Neste caso, o Plano Médio é usado quando atrás do âncora aparece um selo ilustrando o assunto que está falando, ou algum tipo de gráfico. Do contrário, é usado o PP. Geralmente o Plano Geral acontece no final de cada bloco, quando os apresentadores anunciam as chamadas.

Único telejornal apresentado, diariamente, por um só apresentador, o Jornal da Globo teve sua situação alterada em 30 de maio de 2005, quando assumiram os novos âncoras, William Waack e Christiane Palejo. Antes da mudança, no período em que transcorreu a observação, o Plano Médio predominou. $\mathrm{O}$ Plano Geral foi pouco utilizado, ocorrendo geralmente de forma rápida no início e no fim do programa, no momento em que o repórter entrava ao vivo no telão ou quando um convidado participava do programa.

A observação de Muniz Sodré, de que o enquadramento em close se torna um recurso fundamental para adquirir a confiança do telespectador, é bastante relevante no caso da Rede Globo, fato que pode ser bem observado no gráfico 2, que mostra como a emissora faz uso deste plano em todos os seus telejornais, de forma predominante.

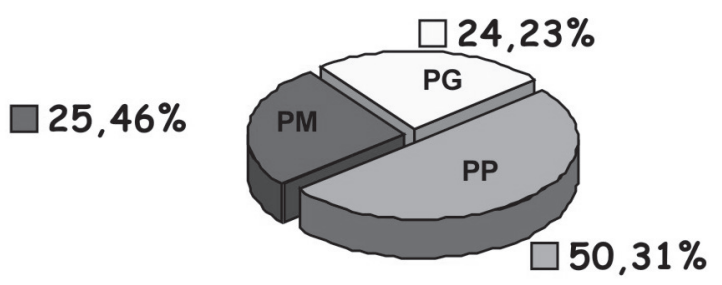

Gráfico 2. Média de enquadramento dos telejornais da Globo Fonte: organização da pesquisa. 
O PP tem um papel essencial na aproximação entre emissor e receptor, pois o "olho no olho" transmite confiança e ajuda o público a perceber se o que está sendo dito é verdade ou não. $\mathrm{O}$ telespectador não consegue distinguir muito bem as expressões faciais do comunicador, quando ele está longe, focado em PG. Os telejornais analisados tenderam a contar com dois âncoras na apresentação, sendo que o Bom Dia Brasil utiliza seus profissionais em Brasília e São Paulo e, além disso, um jornalista especializado em esporte, como espécies de âncoras auxiliares. Ante isso, é importante resgatar a posição de Vieira (1991, p. 123-124), para quem o programa ideal seria aquele que tivesse um apresentador para abrir o programa, o qual passaria a apresentação para um jornalista especializado em cada área, de acordo com os assuntos que fossem surgindo.

Para que um telejornal apresentado por mais de uma pessoa mantenha um tom de naturalidade, é preciso que haja interação entre os apresentadores. Sentar lado a lado na bancada e usar um plano aberto, que mostre que as duas pessoas estão dentro do mesmo estúdio, não é suficiente. É por isso que os âncoras dos jornais televisivos da Globo procuram, através de olhares, gestos e linguagem, criar a ilusão de que o espectador é participante ativo do programa. Alguns noticiários usam este artifício de maneira mais engajada, como o Bom Dia Brasil e o Jornal Hoje. Nestes, no uso do Plano Geral, os apresentadores atuam como se transmitissem a notícia tanto para o público quanto para o colega no estúdio. Neste modelo, as trocas de olhares e os comentários entre eles ocorrem com maior freqüência.

$\mathrm{O}$ único telejornal da Rede que não teve constantemente este tipo de interação entre os âncoras foi o Jornal Nacional, por adotar uma apresentação mais séria, mais formal, com os interlocutores só mostrando ao público estar dividindo a ban- 
cada através de olhares. Quando apareceram em PG, eles deram rápidas olhadas ao colega, passando assim uma impressão de que também estavam contando a notícia um ao outro. Todos os apresentadores dos noticiários utilizaram-se de caras, bocas e gestos para marcar expressões, gerando empatia responsável por atrair o telespectador.

Sandra Annenberg e Ana Paula Padrão merecem destaque especial, entre os apresentadores analisados. Ambas as jornalistas são famosas por suas expressões faciais ao narrar uma notícia. Sandra utilizou muito a "cara fechada" e uma entonação de voz mais grossa quando deu notícias mais pesadas, mais sérias. Já Ana Paula também fez uso de muitas expressões faciais ao introduzir as notícias. As sobrancelhas se encurvavam quando a apresentadora queria dar mais ênfase, chamar mais atenção ao fato dito. Pausas nas falas e pequenas olhadas de canto davam o recado, o tom da notícia. Às vezes um ou outro sorriso, com o canto da boca, colocava uma pitada de deboche na narração. Ao final do programa, a virada para câmera, com um olhar de meiguice e o sorriso amistoso, convidava o telespectador a assistir ao jornal no dia seguinte.

Ainda que também não tenham deixado de usar expressões ou gestos para melhor comunicação, a marca mais comum de Fátima Bernardes e William Bonner foi a forma de expor o acontecimento. Pequenas pausas ou o fato de ressaltarem determinada palavra ao narrar deram o tom que eles pretendiam ao assunto. Após a exibição de uma matéria, no dia $1^{\circ}$ de abril, na qual se mostrou que os fiscais do governo comprovaram a denúncia de trabalho infantil, feita pelo $J N$ no dia anterior, William concluiu a notícia da seguinte forma: 
William Bonner: Os fiscais foram embora, (pausa na leitura) e as crianças continuaram a trabalhar. O Ministério do Desenvolvimento Social anunciou que o município de Santa Maria do Cambucá será inchuído no programa de erradicação do trabalho infantil. (pausa) No mês que vem! (narra bem calmamente está última frase)

As pausas serviram para Bonner mostrar o descaso com que o assunto foi tratado pelas autoridades, tipo de entonação muito usada pelos âncoras dos telejornais. Ao invés de usarem um texto, que pudesse levar a uma opinião mais explícita, optou-se, diversas vezes, por fazer pequenas pausas, ou acentuar determinadas palavras para passar ao telespectador certo ar de opinião.

O discurso televisivo como um todo tem o poder de intimidar quem assiste a um programa de televisão. O telespectador tem a impressão de que a pessoa que está do outro lado do vídeo está falando diretamente a ele, e só com ele. Mesmo que várias pessoas estejam assistindo juntas a um programa, cada uma delas terá a sensação de que o diálogo está sendo instaurado somente com ela. Ao introduzir uma matéria, no texto do apresentador, já são inseridas algumas palavras que terão esta função de dialogar com o público. A Globo usou este tipo de discurso em todos os telejornais analisados.

Tanto no início, quanto no final da grande parte dos noticiários, os apresentadores também cumprimentam o público mais informalmente, a exemplo de Ana Paula Padrão, que iniciava o JG dizendo: "Boa noite pra você". Até mesmo o Jornal Nacional, que se mostrou adepto de uma seriedade bem maior, não fugiu à regra e, no final de cada edição, concluiu o programa usando essa interação.

Além de usarem o "você" para criar uma aproximação com o público, os apresentadores saúdam o telespectador de uma maneira que instaura um reencontro, como se âncora e recep- 
tor fossem pessoas muito próximas, que todos os dias se encontrassem para compartilhar um momento. Isto não deixa de ser verdade, pois quase que diariamente o telespectador está na frente da televisão para assistir ao programa, o que acaba por criar um vínculo com o telejornal.

O texto jornalístico, nos produtos de notícia da Globo, apresentou uma composição simples e bastante objetiva, tendo as frases escritas em ordem direta. Em cada programa coube aos âncoras dar mais ou menos informações sobre o fato. Alguns noticiosos prolongaram a introdução do assunto, enquanto outros o fizeram de forma bem sucinta. Contudo, a maneira que esses dados foram escritos se mostrou praticamente igual nos quatro programas

No Bom Dia Brasil, as chamadas costumam ser bem completas, passando ao telespectador o máximo de informação; no Jornal da Globo é usada uma espécie de título, antes de anunciar a manchete. Alguns telejornais, como o JG, usam um texto direto, mas um pouco mais carregado de coloquialismo. Ana Paula Padrão tinha a liberdade para fazer uso de metáforas, dando assim um tom um pouco mais leve aos assuntos, que geralmente são bastante voltados à economia e à política.

Uma outra prática que se mostrou bastante comum nos telejornais foi o diálogo em tom de brincadeira entre os apresentadores. Isso foi bastante adotado no Bom Dia Brasil e no Jornal Hoje: nesses programas, dependendo do tema que estava em pauta, os âncoras se permitiam estender o assunto e brincar entre si e com o público. Numa das edições do $J H$, Sandra Annenberg e Evaristo Costa deram boas gargalhadas enquanto apresentavam uma nota coberta: 
Sandra Annenberg: E uma imagem que veio do Japão, hoje, promete dar que falar. O primeiro ministro japonês, Junichiro Koizumi, tirou o astro de Hollywood, Richard Gere, para dançar. Primeiro a surpresa. Alguém lembra de um primeiro ministro japonês tão animado? Pois Koizumi aproveitou o título do filme, que Gere está lançando no Japão, e não teve dúvidas: 'Quer dançar comigo?' O ator, meio constrangido, entrou no ritmo. Eo mais engraçado é que eles até parecem irmãos gêmeos, não parecem não? Dá só uma olhadinha (fala rindo). Depois dessa, você não vai se animar, e me tirar pra dançar aqui não?- diz a Evaristo Costa.

Evaristo Costa: Sentados não, a hora que a gente ficar em péa gente dança.

Sandra Annenberg: Depois do jornal. - fala dando risada.

Concluída a apresentação de mais algumas informações, os dois se despedem e Evaristo aproveita para brincar mais uma vez com o telespectador.

Evaristo Costa: Nós vamos dançar agora, né? Uma boa tarde pra você também e atéamanhã.

Ambos os âncoras caíram na risada, enquanto os créditos iam subindo, um uso mais coloquial, no tom de apresentação das notícias, que acaba por deixar o telejornal mais natural aos olhos de quem assiste. Apesar do dispositivo, e do próprio interlocutor, ainda serem construídos em cima de um modelo que já pendura por anos, essas pequenas colocações vão dando um novo rumo ao telejornalismo e à figura do apresentador. Ele ganha mais liberdade, até para inserir um ou outro comentário mais pessoal à narração.

Condenado por muitos autores, o gênero pessoal e opinativo pôde dar pequenas pinceladas no decorrer de alguns noticiários da televisão. A análise demonstrou que o Jornal da Globo 
adotou tal gênero na abertura do programa, quando diariamente Ana Paula Padrão fazia uma espécie de editorial sobre a principal manchete do dia.

Muito usado nos telejornais foi o tom pessoal, do eu, do nosso. Passou o tempo em que as narrações desses programas da Globo eram apenas em terceira pessoa, e que os âncoras se restringiam a dar a notícia sem agregar nenhum comentário pessoal a ela. Mesmo no telejornal mais tradicional da emissora, houve alguns casos em que o toque pessoal foi posto em prática pelos apresentadores.

\section{Considerações conclusivas}

A Globo constrói de diversas formas discursivas os apresentadores dos seus principais telejornais. ${ }^{7}$ Quesitos, como a aparência, são praticamente padrão em todos os programas, enquanto outros, como linguagem mais informal e postura mais relaxada, são típicos do Bom Dia Brasil e do Jornal Hoje, o que é perceptível a qualquer telespectador. Na maior rede de televisão do país fica bastante evidente que os noticiários matutinos construíram a imagem do âncora de uma forma mais liberal, enquanto que o Jornal Nacional, apesar de algumas inovações, ainda manteve um certo grau de formalidade.

O JN trabalha com a suposição de que as pessoas que param para assisti-lo fazem parte de um público mais diversificado, o que abrange desde um trabalhador de chão de fábrica até o presidente da corporação. Por esse motivo o telejornal não abusa da informalidade, visando atingir assim a todos os telespectadores. Ao mesmo tempo, a formalidade ajuda a manter o valor simbólico de principal jornal televisivo do país, que prima so- 
bretudo pela credibilidade. A informalidade não necessariamente leva a uma descrença do público no programa, mas o formal acaba, de certa forma, induzindo a uma seriedade muito maior. Cada programa, apesar de ter um cenário mais ou menos parecido, fazendo uso da tradicional bancada, acabou por adotar um estilo diferente. O Bom Dia Brasil deu mais liberdade de movimento aos âncoras, que podiam, inclusive, circular pelo cenário enquanto davam a notícia. Mantendo a sua pose de formal, o Jornal Nacional não permitiu aos seus apresentadores muita mobilidade, a postura sempre apareceu bem centrada no vídeo. Mesmo quando William Bonner ancorou o telejornal em pé, direto do Vaticano, a imagem pela qual ele era enquadrado, PP ou PM, mostrava pouco do apresentador, não permitindo que ele caminhasse ou aparecesse de corpo inteiro. Pelo enquadramento, o telespectador podia até pensar que William estava sentado. Tal característica desse noticioso ficou bastante visível quando Sandra Annenberg e Renato Machado assumiram, em algumas edições, o comando do $J N$. Os dois jornalistas são os âncoras do Jornal Hoje e do Bom Dia Brasil, respectivamente, e durante a apresentação do $J N$ mudaram completamente de postura.

Como foi possível observar na análise da amostragem, e conforme Muniz Sodré já afirmava, o Primeiro Plano (PP) foi o recurso mais usado pela TV para aproximar o enunciador e o receptor. O PP foi usado em todos os telejornais da Globo, procurando, sempre que a notícia fosse de maior impacto, aproximar bem o rosto do apresentador, para que o público pudesse perceber a importância do assunto. O uso do Plano Geral, que traz ao telespectador uma visão geral do programa, manteve o cenário de espetáculo e a sensação de que os âncoras estavam juntos dando a notícia, em harmonia um com o outro. 
A emissora também construiu, em alguns telejornais, um texto em forma de diálogo, que veio a fazer com que os dois apresentadores realmente conversassem um com o outro. A sensação que se passou ao público com isso foi de um verdadeiro "bate-papo". Apesar do Jornal Nacional ser o que menos buscou essa interação entre os interlocutores através deste tipo de diálogo, o programa não deixou de usá-la. Na situação em que os âncoras ancoraram o programa de locais diferentes, eles tiveram a liberdade de se chamar pelo nome e instaurar pequenos diálogos, mais para mostrar ao público que ambos estavam em locais diferentes. Nota-se que o JN se dá o direito de usar de um certo grau de informalidade quando leva o comunicador para fora do estúdio, como se a inovação da ancoragem da rua também permitisse ao telejornal usar outras formas discursivas.

As expressões faciais e a entonação do discurso de cada apresentador também tornam-se uma espécie de marca dos jornais televisivos. Quem assistia ao Jornal da Globo, durante a ancoragem de Ana Paula Padrão, já esperava por uma linguagem discursiva que enfatizava os movimentos de cara e boca da apresentadora, a qual passava o recado através de olhares e pequenos expressões labiais, que davam ao público todo o toque de opinião à notícia. Fátima Bernardes e William Bonner até tentaram usar expressões um pouco mais firmes para diferenciar a matéria, no telejornal mais formal da emissora, mas foi principalmente na entonação das frases e no uso das pausas que eles criaram um ponto de vista próprio sobre a notícia.

Todavia, há outro ponto em que todos os telejornais da emissora se assemelham: o uso de um discurso que constantemente usa o "você", que praticamente chama o telespectador pelo nome. Os apresentadores, através de frases como você está ven- 
do ou o que você acha disso, colocam o receptor dentro do televisor, o que foi percebido em todos os programas analisados. Tradicionalmente temida na principal emissora do Brasil, a opinião dos âncoras virou realidade em seus telejornais, o que, aos telespectadores mais desatentos, pode até passar despercebido ou ser confundido com informação. A notícia de abertura do Jornal da Globo abria claramente as portas do jornalismo opinativo, mas no Jornal Nacional, e até nos demais noticiosos da emissora, a linguagem opinativa ainda é apresentada muito sutilmente.

Via de regra, a Globo molda o seu apresentador de acordo com o público de cada telejornal, como se ela fizesse uso de diversas construções discursivas para conseguir capturar os mais diversos receptores. Há na emissora desde um programa jornalístico bem informal até um carregado de formalidade. Se o Bom Dia Brasil, o Jornal Hoje e o Jornal da Globo inovaram muito o formato discursivo dos seus âncoras, modernizando-os e os aproximando do seus respectivos públicos ao longo dos anos, o Jornal Nacional, apesar de algumas inovações, ainda lembra a apresentação que era feita durante muitos anos pelos locutores Cid Moreira e Sérgio Chapelin. Compreender o âncora é um passo importante para entender o telejornalismo brasileiro, pois quando se analisa esta figura é possível perceber toda a linguagem discursiva de uma emissora. Deste modo abrem-se as portas para o esclarecimento dos objetivos que ela busca para se fazer confiável e ganhar, com isso, o voto do telespectador.

\section{Notas}

${ }^{1}$ No Brasil, o âncora "foi implantado de forma diferenciada e particular", comparativamente com o modelo norte-americano, apesar dos Estados Unidos ter fornecido o padrão de apresentação de telejornais. (SQUIRRA, op. cit., p. 183). 
${ }^{2}$ Os telejornais costumam invadir a casa dos telespectadores nos horários e nos locais - salas e cozinhas - onde a família geralmente encontra-se reunida.

${ }^{3}$ Porém, na edição de $1^{\circ}$ de abril, Renata foi substituída por Maria Beltrão e, na semana de 4 a 15 de abril, Márcio Gomes ocupou o lugar de Renato.

${ }^{4}$ No dia 9 de abril, o programa foi apresentado por Mariana Godoy, que também substituiu Sandra de 20 a 22 de abril. Priscila Brandão apresentou oJH no dia 16 de abril; no dia 23 de abril somente Evaristo Costa esteve na bancada do $J H$.

${ }^{5}$ A edição de 9 de abril foi apresentada por Chico Pinheiro e Carla Vilhena, e a de 16 de abril, por Sandra Annenberg e Alexandre Garcia. Dos dias 20 a 22 de abril o telejornal foi apresentado por Sandra Annenberg e Heraldo Pereira, enquanto a edição de 23 de abril ficou a cargo de Heraldo Pereira e Renato Machado.

${ }^{6} \mathrm{O}$ horário altera-se em razão do telejornal ser transmitido após os programas que sucedem a telenovela das $21 \mathrm{~h}$, os quais têm duração variável.

${ }^{7}$ Em regra, apresenta-se os dados coletados no tempo verbal pretérito, por remeterem ao período analisado. No entanto, sabe-se que a maioria das observações coletadas mantém-se como características gerais dos produtos.

\section{Referências}

BARBOSA, Marialva; RIBEIRO, Ana Paula Goulart. Telejornalismo na Globo: vestígios, narrativa e temporalidade. In: BRITTOS, Valério Cruz; BOLAÑO, César Ricardo Siqueira (Orgs.). Rede Globo: 40 anos de poder e hegemonia. 2ed. São Paulo: Summus, 2005.

JAKOBSON, Roman. Lingüística e comunicação. São Paulo: Cultrix, 1968.

NETO, Antônio Fausto. O impeachment da televisão: como se cassa um presidente. Rio de Janeiro: Diadorim, 1995.

SODRÉ, Muniz. O monopólio da fala. Petrópolis: Vozes, 1989.

SQUIRRA, Sebastião. Boris Casoy: o âncora no telejornalismo brasileiro. Petrópolis: Vozes, 1993.

TRAQUINA, Nelson. O estudo do jornalismo no século XX. São Leopoldo: Ed. Unisinos, 2001.

VIEIRA, Geraldinho. Complexo Clark Kent: são super-homens os jornalistas? São Paulo: Summus, 1991. 



\section{Análise da imagem na imprensa}

Um percurso em busca da discursividade na fotografia

Giovandro Marcus Ferreira

\section{Do imenso reino da imagem}

A palavra imagem suscita uma fabulosa riqueza de sentido, pois ela é usada de diferentes maneiras e em diversas ocasiões. Isso dificulta uma definição simples deste termo. A própria etimologia da palavra já evidencia esta riqueza de sentido. "Imaginem" acusativo de imago "imagem", deriva "representação", "retrato", "fantasia" e "aparência", em oposição à realidade, igualmente o termo de retórica como figura. Imago supõe um radical im- de origem obscura que estaria na base do verbo imitari, imitar. 
Em latim, inicialmente, imagem tem o sentido de "estátua" (= imagem de Santo, estátua de Duque de Caxias, dos Bandeirantes...). A palavra designa igualmente uma visão ao longo de um sonho, da representação gráfica de um objeto ou de uma pessoa. Assim, logo é cunhada a locução "uma bela imagem”, ou então, ídolo (termo empregado por alguns filósofos da Grécia antiga, especialmente Demócrito e Epicúrio para designar as representações 'enviadas' pelas coisas aos nossos sentidos) $)^{1}$, A palavra se reforça, ao longo do tempo, para expressar a reprodução ou imitação de alguma coisa ou de alguém, "na imagem de", "na semelhança de". Destacando o papel da imagem, pode-se ver sua relevância em obra como Odisséia de Homero onde o jogo de imagens cria densidade na narrativa e prolonga os caminhos de Ulisses no seu longo percurso de volta para casa. Posídon na sua irritação transforma a nau em imagem de rochedo, Ulisses ao acordar não reconhece na imagem em que vê sua terra natal, a deusa aparece na figura de jovem pastor, Ulisses desconfiado se faz passar por uma imagem de cretense fugitivo...

Nas religiões antigas e modernas, a questão das imagens atravessam tempos e templos. Mais uma vez a imagem, também, aqui tem a expressão de ídolo. No Egito, na Síria e na Mesopotâmia é difícil se ter a dimensão do valor da imagem naquele contexto religioso. "A imagem era algo mais que mera representação, mas ao mesmo tempo não se conformava simplesmente com o deus. O templo e a imagem eram as contrapartes terrenas da realidade celeste, e eram os únicos meios mediante os quais o culto podia chegar aos deuses. Nesta base, a imagem era tratada como seria tratado o próprio deus, e o tratamento era o mesmo que o cortesão prestava ao monarca. Tanto no Egito como na Mesopotâmia, de manhã o deus 
era acordado, lavado ou purificado ou ungido, vestido e serviam-lhe as refeições. Não obstante sabia-se que era uma imagem! Tanto no Egito como na Mesopotâmia o culto matutino compreendia o rito da "abertura da boca", com o qual a imagem era animada para receber o culto e as petições dos fiéis do deus. No Egito e na Babilônia a imagem era levada como hóspede aos templos de outros deuses, cujas as festividades eram celebradas. Isso tudo, entretanto, não era idolatria no sentido rude da plavra: sem imagem divina não era possível prestar culto ao deus." 2

$\mathrm{Na}$ concorrência e auto-afirmação religiosa assistimos, igualmente a proibição de toda e qualquer imagem (Ex 20, 4-6; Dt 5, 8-10; cf. Lv 26,1; Dt 4, 15-23) "nem no alto, nos céus; nem em baixo, na superfície da terra, nem nas águas, debaixo da terra". Segundo Mckenzie, "Ihaweh não podia ser representado por imagens porque nenhuma imagem podia representálo. Era inteiramente diferente de qualquer objeto da natureza; representá-lo em imagem teria significado de reduzi-lo ao nível da natureza e, por conseguinte, rebaixá-lo ao nível das divindades adoradas mediante imagens."3

Em torno da questão da imagem (idolatria) vamos assistir ao longo dos séculos uma luta veterotestamentária. Tal questão se prolonga por outros agrupamentos contemporâneos, dividindo pessoas que professam crenças paralelas, mesmo que todos eles partam do princípio que se encontra a imagem como centro da fé: "O homem é a imagem de Deus" (Gn, 1, 26s). Tanto na origem da crença como no fim da vida, lá vemos a imagem sendo solicitada para a continuação ou o prolongamento do contato. É bom lembrar que um dos sentidos de imagem em latim, designa a máscara mortuária levada nos funerais na antiga Roma. Isto nos faz pensar nas pinturas realizadas sobre a os sarcófagos 
na região Fayounm (Egito), no início da era cristã - imagens egípcias pelo simbolismo, gregas pela técnica pictural e romana pelo contexto social, admiradas ainda hoje, como os misteriosos "ícones" do mundo antigo. Lá vemos, uma representação que busca prolongar o contato resguardando uma analogia com o ser representado. Pode-se notar a matrona severa exibindo suas bijuterias, a jovem mulher com seu leve sorriso rebelde e o olhar ávido de vida; o adolescente com lábios sensuais, acompanhados de seus primeiros pêlos dispersos no rosto, como se tivesse saído de um filme de Pasolini... Outra com um ar entediado, como se Madame de Bovary tivesse existido em outros tempos mergulhada na sua doce melancolia... Eis homens, mulheres, crianças, jovens... arrancados do esquecimento que se tenta hoje através destas imagens, de seus retratos, sobre finas placas de madeiras, adivinhar aspectos do contexto de outrora, mergulhar, num quase relacionamento, nas imagens-perfis que desfilam sobre este último leito. ${ }^{4} \mathrm{~A}$ imagem, neste caso, nos remete ao espectro ou a alma do morto, mas igualmente a história da arte e dos ritos funerais.

Nas línguas neo-latinas, a palavra imagem corresponde "a uma reprodução invertida que uma superfície polida oferece de um objeto que se reflete". De maneira abstrata, a imagem entra, já no latim, no vocabulário da retórica (por imagem e por comparação, B. Latini). A palavra se refere à evocação no discurso de uma realidade diferente desta a qual envia o sentido próprio do texto, mas que resta ligado por uma relação de analogia (a metáfora, por excelência).

A partir do século XVIII, imagem torna-se a palavra chave da psicologia. A palavra designa (DESCARTE, 1647) a reprodução mental de uma percepção ou impressão, na ausência do objeto que lhe havia dado origem, neste sentido, agora ligado à 
imaginação, onde utilizou-se indistintamente idéia ou imagem até meados do século XVIII. Em seguida, imagem vai se opor de uma parte a realidade, as coisas, e de outra, ao conceito, a idéia abstrata. No século XIX, a importância das representações planas, as gravuras se tornam relevantes pela aparição de novas técnicas. Colocadas em relação ou não com os textos impressos, as imagens são reproduzidas pela fotografia. Já mais recente as novas técnicas são produzidas e a imagem é estendida a outros meios de comunicação como o cinema, a televisão, e mais recentemente, ao computador. Eis, então, a riqueza, nesta sumária apresentação, que mostra como a imagem - objeto da cultura visual - nos é apresentada "suja e rica de história”.

\section{Da semiologia da imagem}

Falar, então, de Mídia \& Cultura visual nos deparamos com este enorme panorama, com perguntas transbordando sentido: o que é uma imagem? Como estudar este objeto tão polissêmico? Podemos pensar num estatuto por categorias de imagens?

Na história das teorias da comunicação podemos explorar o estudo da imagem a busca de compreendê-la como signo, logo, estamos ancorando nossa exposição a teoria do signo, ou seja, a teoria semiótica. As teorias da comunicação nos inscrevem no âmbito das imagens mediáticas, neste contexto vamos restringindo a noção de imagem como objeto de análise. Numa perspectiva semiótica estudar certos fenômenos ligados a imagem é problematizar sobre a significação e não sob o ângulo da emoção ou do prazer estético. Busca-se conhecer o modo de produ- 
ção do sentido, sua maneira de provocar significações, interpretações. Como diz Martine Joly,

o trabalho do semioticista consistirá, antes de mais nada, de tentar ver se existem categorias de signos diferentes, se estes diferentes tipos de signos têm uma especificidade e de leis próprias de organização, de processos de significações particulares. ${ }^{5}$

Nesta perspectiva que podemos situar as questões que Barthes levanta em busca da construção de uma semiologia da imagem e demarca um terreno que irá influenciar outros pesquisadores, mesmo que tais questões ultrapassem as respostas oferecidas pelo autor: Como o sentido vem a imagem? Onde o sentido termina? E se ele termina, o que tem além? A partir destas questões, Barthes busca justificar o estudo da fotografia, onde ele elabora textos que vamos aborda mais adiante. Porém, gostaríamos de fazer algumas observações acerca da obra de Barthes, no tocante ao tema aqui tratado. A questão da imagem é central na reflexão deste autor que irá influenciar os estudos das imagens em geral e da fotografia em particular. Se Saussure tinha a arbitrariedade do signo como seu Mefistófeles, Barthes, por seu lado, elegeu a analogia, ou como ele já chamou "o demônio da analogia".

A palavra analogia carrega na sua etimologia uma grande pretensão. Ela busca corresponder à proporcionalidade, associação, semelhança, imitação, elo, em relação ao objeto representado. O seu oposto é a anomalia no tocante à representação. Daí o interesse de Barthes nas artes analógicas (cinema, fotografia) e métodos igualmente analógicos (crítica universitária). No fundo de sua reflexão, há uma interrogação que perpassar várias de suas obras (fortemente presente no início de sua produção), que pergunta se a humanidade está condenada a analogia? Assim 
Barthes vai construir um empreendimento para demolir os mitos da modernidade construídos sobre uma pretensa analogia: neutralidade dos discursos racionais e a abundância de enunciado, que pretensiosamente tenta ser denotativo, camuflando a construção de mitos, ou seja, a deformação de um sentido histórico a serviço de uma ideologia. $\mathrm{O}$ avanço da reflexão de Barthes sobre os objetos mediáticos é uma denuncia ao duplo modo de existência em que eles estão submetidos, a partir do qual se forja o mito: simulação (parece ser o que não é) e dissimulação (não parece ser o que de fato é).

No interior destas preocupações que Barthes especifica sua análise acerca dos objetos dos mass media, transformando-os em objetos semiológicos, que vão compor as mitologias da modernidade das sociedades tecnológicas. Uma perspectiva interessante que Barthes vai adotar em relação ao signo, será de grande interessante para o estudo da imagem: o sentido não é propriedade do objeto, mas do uso que fazemos deste objeto. Todo o uso do objeto, acaba se transformando em objeto do uso. ${ }^{6}$

No tocante ao estudo da imagem, um ponto relevante na reflexão de Barthes é o estudo da fotografia. No artigo, "A retórica da imagem", Roland Barthes vai ressaltar a importância do aparecimento da fotografia enquanto uma "revolução antropológica na história do homem". ${ }^{7}$ Segundo ele, a há um tipo de consciência implícita nesta nossa maneira analógica, que ao seu olhar, sem precedente, que instaura uma consciência que não é do estar aqui do objeto, mas do ter estado aqui. Esta nova consciência "é uma nova categoria de espaço-tempo, uma categoria ilógica entre o aqui e o antigamente." Esta perspectiva imagética é inusitada e Barthes faz uma comparação entre o cinema e a 
fotografia. O cinema não seria fotografia animada: nele o ter estado aqui desaparece, em detrimento ao estar aqui do objeto.

Mais tarde, em 1980, no livro intitulado "La chambre claire note sur la photographie", Barthes situa o debate além da analogia e vai se concentrar sua atenção sobre o tempo da fotografia.

Se perguntar se a fotografia é analógica ou codificada não é uma boa via de análise. O importante, é que a foto possua uma força de constatação e que esta constatação da foto situa-se, não sobre o objeto, mas sobre o tempo. ${ }^{9}$

Uma outra pista interessante, nesta última publicação de Barthes, é o paralelo feito entre a fotografia e a irrupção da vida privada no âmbito público, ou como ele diz "à criação de um novo valor social, que é a publicidade privada: o privado é consumido como tal, publicamente." ${ }^{10}$

Além das observações sobre o noème (unidades semânticas de difícil acesso) da fotografia, Barthes ajuda a reflexão neste domínio, mesmo realizando uma análise imanente da fotografia, com uma análise que não isola o material verbal do icônico. Elabora funções da mensagem verbal em relação à mensagem icônica, ou melhor, em relação à "cadeia flutuante" de significado que ela provoca. Ele estabelece a função de fixação, de conhecimento, de imobilização e de relais. ${ }^{11}$ A primeira busca restringir ou fixar a cadeia flutuante dos significados ou de "combater o terror dos signos incertos". A mensagem lingüística ajuda identificar a cena e os elementos que a compõem. A função fixação é empregada com freqüência no fotojornalismo e na fotopublicidade. A função de conhecimento serve para recuperar ou acrescentar informações não explícita na imagem. A terceira função - de imobilização dos níveis de percepção - tendo em vista a polissemia da imagem, ao nível dos significados conotativos, o texto ocupa-se de sua inteligibilidade. Por últi- 
mo, a função relais, que é menos freqüente, sobretudo em relação à imagem fixa, mas está mais presente em imagem em movimento. Esta função tem uma relação de complementariedade, bem freqüente no cinema e nas histórias em quadrinhos na progressão das ações. ${ }^{12}$

Comentamos este estudo de Barthes por duas razões. Um primeira pela importância que este teórico desempenhou no interior das teorias da comunicação, pela contribuição da semiologia. Uma segunda razão, é que esta perspectiva de análise vem reforçar uma tendência no interior da análise do discurso que busca estudar a imagem, além do material verbal, e mais, faz uma investida levando em consideração a multiplicidade das matérias significantes (verbal e não-verbal).

Esta ótica de estudo dos signos, eleva o estudo da imagem, a partir da semiótica da imagem, deixando para trás certas doenças infantis deste domínio como caracterizava Christian Metz, onde se sustenta uma oposição entre o "analógico e o codificado". Há um processo analítico, como ressalta este autor: Num primeiro momento busca-se enfatizar a distinção de modo mais manifesto da imagem e outros objetos significantes - seus estatutos "analógicos", ou sua "iconicidade". Após esta investida fica o desafio de "desiconizar" o ícone, já que a história da semiótica, segundo ele, "iconizou" bastante o ícone. ${ }^{13}$

Preconiza, então, Metz que a semiologia ou semiótica da imagem será feita ao lado da semiologia dos objetos verbais, com interseção já que muitas mensagens são mistas, como são por excelência as mensagens mediáticas: jornalismo impresso, publicidade, entre outras. Ele destaca ainda: "A nossa intenção não é negar a analogia, mas circunstanciá-la e relativizá-la”. ${ }^{14}$ Idem ibidem. 
A imagem não constitui um império autônomo e cerrado, um mundo fechado sem comunicação com o que rodeia. As imagens - como as palavras, como todo o resto - não poderiam deixar de ser "consideradas" nos jogos de sentido, nos mil movimentos que vêm regular a significação no seio das sociedades. A partir do momento em que a cultura se apodera do texto icônico - e a cultura já está presente no espírito do criador de imagens -, ele côo todos os outros textos, é oferecido à impressão da figura e do discurso. A semiologia da imagem não se fará fora da semiologia geral. ${ }^{15}$

Esta perspectiva traçada por Christian Metz não pretende anexar o estudo da imagem ao campo lingüístico, mas uma advertência ao seu "isolamento na contemplação indefinida de sua iconicidade, a cortá-la de qualquer outra consideração, a mutilála de mil laços que o unem à semiologia geral e a uma reflexão sobre as culturas". De outra forma, pode-se dizer que "nem tudo que está no ícone é icônico e existe o icônico fora do ícone." ${ }^{16} \mathrm{Tal}$ afirmação é uma boa pista para se pensar a fotografia enquanto matéria significante integrante a um determinado discurso, constituído por outras matérias significantes, que juntas vão edificar o seu sentido.

\section{Do discurso da fotografia no suporte de imprensa}

A recusa do isolamento do material não-verbal, num primeiro momento, em relação ao material verbal, e num segundo momento em relação as suas condições sociais, cria-se a possibilidade de repensar o sentido a partir de multiplicidade de matérias significante, numa semiosis histórica e infinita. Com isso se quer dizer que todo objeto significante é produzido num determinado contexto histórico, circula no meio social e é con- 
sumido de maneira real e/ou simbólica. Neste sentido, toda análise do discurso implica um certo dispositivo que é "uma espécie de "fragmento do tecido semiótico 'arrancado' do fluxo da produção social do sentido". ${ }^{17}$

Com tais afirmações acima, se está num outro contexto teórico-metodológico no tocante ao signo. As investidas que retratamos em Barthes e Metz, a maioria dos artigos citados se encontra no interior de uma época caracterizada como imanentista, onde se trabalha sobre um corpus e se ia em busca de seu sentido conotativo. Era a época de valorização da mensagem em si. Esta fase é considerada por muitos como a semiologia de primeira geração, ou semiologia dos anos 60. Já a semiologia de segunda geração, ou dos anos 70, procura ir além de um ponto de vista estático e taxionômico e se coloca como objetivo a busca da produção de sentido, sob a influência das "gramáticas generativas". A partir do texto estudado, tratava-se de reconstruir o processo de engendramento de sentido. Esta fase tem como obra clássica, o livro de Julia Kristeva ${ }^{18} \mathrm{O}$ estudo do discurso entra no ano 80, numa outra fase, onde se busca integrar não só as condições de produção (engendramento), mas as condições de recepção, consumo ou reconhecimento, numa perspectiva de, igualmente, articular agora uma teoria dos "efeitos de sentido" ${ }^{19}$

O estudo da imagem em geral e/ou da fotografia em particular se encontra inserida no interior destas grandes perspectivas analíticas do discurso. Nesta terceira fase, a problemática da enunciação tem uma importância capital. A enunciação, que se constrói em torno do enunciador e destinatário, sujeitos discursivos, tem um dispositivo que comporta: (1) A "imagem" ou o lugar daquele que fala, (2) o lugar ou "imagem"daquele a quem a fala é endereçada, e (3) a relação entre o enunciador e o 
destinatário, que é proposto pelo discurso em questão. Através do dispositivo de enunciação - da maneira de dizer e não do conteúdo, do enunciado - proposto por um determinado suporte de imprensa, pode-se analisar as expectativas, as motivações dos leitores levados ou não em conta, o posicionamento de um determinado suporte em relação à evolução sócio-cultural, assim como seu posicionamento em relação aos demais concorrentes.

Nesta ótica a análise ou estudo do discurso não está mais em busca do lado conotativo ou escondido da mensagem, nem tampouco se irá dissolver o discurso no "caldeirão" da ideologia. A concepção de estudo de discurso, que nos sentimos mais próximo, não abandona o conceito de ideologia, mas o coloca numa posição descritiva, designando uma formação histórica, um conjunto de idéias, um sistema de representação. Ela não tem o estatuto teórico, como passa a ter a noção de ideológico e poder. A primeira noção designa não um conjunto observável de "coisas" ou de opiniões, mas uma dimensão de análise do funcionamento social. A análise ideológica da produção social do sentido não é nada mais que a " pesquisa das pistas que estes níveis de funcionamento social deixam nos discursos sociais" ${ }^{20}$. A segunda noção - poder - é o nome que designa o sistema de relação entre um discurso e suas condições sociais de consumo ou reconhecimento. Aqui o conceito poder designa a problemática dos efeitos de sentido dos discursos. A noção de ideológico e poder concernem uma dimensão de todo o discurso e de toda produção de sentido que circulam na sociedade. Preocupada com as condições de produção, circulação e reconhecimento, a análise do discurso vai se interessar sobretudo pelos aspectos espacio-temporal do sentido, ou melhor, "um discurso não é em definitivo nada mais do que uma tomada em espaço-tempo do sentido". ${ }^{21}$ 
Nesta nova perspectiva de trabalhar o discurso, que podemos situar os trabalhos vindouros no tocante à fotografia na imprensa. Eliseo Veron, em um artigo publicado pela Université de Louvain-La-Neuve, busca uma sistematização da relação texto-imagem a partir de capas de revistas (Le Nouvel Observateur, L'Express, Minute...). ${ }^{22}$ Apesar das limitações de tal sistematização ${ }^{23}$, o autor avança no estudo da fotografia e 12 anos depois, em 1994, publica um outro artigo, intitulado "De l'image sémiologique aux discursivités - le temps d'une photo", que tenta explicar, inicialmente, entre outras, o insucesso de uma eventual semiologia da imagem e mergulhar mais a fundo neste universo metodológico que acabamos de fazer alusão. ${ }^{24}$ Após uma retrospectiva do estudo da imagem, tendo como destaque a produção de Barthes e Metz, Veron faz, embasado em ambos, mas sobretudo em Barthes, a relação entre a gênese da fotografia, como suporte do individualismo moderno, onde uma estratégia enunciativa que era associada a um suporte, no caso a pintura, é deslocada para um novo suporte, a fotografia. Veron afirma, sempre próximo da reflexão de Barthes, que

sem paradoxo, nós podemos dizer que é a temporalidade que está no coração da técnica, que a torna apta, através de múltiplas formas, à tratar as relações entre os espaços mentais do público e do privado. ${ }^{25}$

Nesta ótica pela qual os meios de comunicação fornecem o essencial para que os indivíduos estruturem sua singularidade, a fotografia tem um papel central sob várias formas. Posicionando o suporte fotografia num contexto discursivo mais amplo, que sobredetermina o funcionamento da imagem, Veron evoca algumas "figuras" própria da fotografia mediatizada 
na imprensa escrita de informação: A fotografia testemunhal, a pose, a retórica das paixões e a fotografia categorial.

- A fotografia testemunhal: é uma das modalidades mais tradicional do fotojornalismo. Ela é a foto reportagem tomada no "momento do fato", ou na "captação do acontecimento". Esta categoria representa o "presente puro", o "ter estado aqui". Porém, Veron ressalta que este tipo de fotografia, contrariamente que poderia se imaginar, não representa a maior quantidade de fotos de um suporte de informação impressa.

Poucas imagens, na imprensa de informação atual, têm uma ligação propriamente factual em relação ao que é contado no artigo... o enunciador dos mass média diz bem que sua intenção não de nos mostrar a atualidade, mas de nos dizer o que ele pensa. ${ }^{26}$

- La pose: é um presente, uma oferta, do personagem fotografado ao fotógrafo, diferentemente da foto testemunhal que é uma "extração do acontecimento" (a revista Caras trabalha com freqüência com a foto pose nas suas capas). A foto pose vem sempre assinada por uma marca e o tempo desta foto não é mais o mesmo do tipo de foto precedente. Nem mesmo quando a foto testemunhal antiga é retomada em publicações recentes. Há um jogo entre o "ter estado aqui" e "estar ainda aqui", como parte do contrato de certos veículos, onde buscam construir uma rede cognitiva, articulando a temporalidade do mundo à bibliografia do indivíduo.

- A retórica das paixões: é uma outro tipo de foto bastante freqüente vis-à-vis aos homens políticos. Ela busca retratar o "estado de espírito" do homem público, expressando com isso uma certa conjuntura. Segundo o autor, trata-se de um caso particularmente complexo da temporalidade fotográfica. Uma fotografia expressiva desta categoria foi publicada pela revista 
Época, $n^{\circ} 175$ (24/09/2001), logo após a derrubada das torres gêmeas. Há uma foto da cabeça de Bush, olhando para o infinito, rodeada de militares (soldados, paraquedistas). Como título, embaixo da página: "A caminho da guerra". Eis uma capaconjuntura, ou seja, retórica das paixões.

- A fotografia categorial: é uma imagem quase enciclopédica, de imagens quase conceitos. Ela opera sobre a dimensão categorial da evolução individualista. Pode-se, por exemplo, ter um título de capa: "Mulheres que moram sozinhas". Ao lado aparece uma mulher qualquer, representando a "categoria" da mulheres que vivem naquela situação. Ou então, a "volta a escola". Uma foto de uma criança com os trajes escolares.

Estas "figuras", em torno da fotografia da imprensa, apesar de ser uma classificação, não busca ser exaustiva, e pode ajudar na pesquisa dos estudos comunicacionais indo além das características da fotografia enquanto tal, em especulações que muitas vezes mutilaram e mutilam ainda o sentido das mensagens mediáticas em análise. Nesta fase atual da análise do discurso, no interior do pensamento comunicional, busca-se posicionar a fotografia como matéria significante juntamente com outras matérias que compõem o discurso, no caso da imprensa escrita de informação em questão, numa ótica que ressalta as condições de produção, circulação e de consumo do discurso.

Neste novo patamar sobre o qual se encontra a análise do discurso, as matérias significantes, incluso a fotografia, serão indícios, ou melhor, pistas para os pesquisadores do discurso mediático conhecerem: (1) as relações que se estabelecem entre os suportes mediáticos e seus públicos, (2) a maneira como se comportam um conjunto de suportes mediáticos numa determinada zona de concorrência, (3) além de conhecer igualmente como estes mesmos suportes se posicionam em rela- 
ção a evolução sócio-cultural. Deixamos para trás uma análise imanente e com ela a pretensão de construir uma semiologia da imagem ou uma semiótica visual, para reposicionar a imagem no conjunto de outras matérias significantes e analisá-las a partir de uma rede interdiscursiva da produção de sentido que é social, infinita e histórica.

\section{Referências}

BARTHES, R. Le système de la mode. Paris: Seuil, 1967.

BARTHES, R. La chambre claire - notes sur la photographie. Paris : Éditions de l'Étoile/Gallimard/Le Seuil, 1980, p. 138-139.

BARTHES, R. A retórica da imagem. In: O óbvio e o obtuso- ensaios críticos III. Rio de Janeiro: Nova Fronteira, 1990, p. 27-43.

FERREIRA, Giovandro, O discurso jornalístico numa perspectiva histórica. In: BARBOSA, Marialva, Estudos de jornalismo I. Campo Grande: Edições do Mestrado em Comunicação, Imagem e Informação da UFF, 2001, páginas 143-160.

FERREIRA, Giovandro, Estudos dos mass media: diversidade, desdobramentos e convergências. In Revista Brasileira de Ciências da Comunicação, n. 2, v. XXIV. São Paulo: Intercom, julho/dezembro de 2001, p. 137-149.

GEOFFROY-SCHNEITER, Berenice. Fayoum. Paris: Éditions Assouline, 1998. JOLY, M. Introduction à l'analyse de l'image. Paris: Éditions Nathan, 1994.

LOPES, Edward. A identidade e a diferença. São Paulo: Edusp, 1997.

KERBRAT-ORECCHIONI, Catherine. L'énonciation - de la subjetivité dans le langage. Paris: Armand Colin, 1980.

KRISTEVA, J. Recherche pour une sémanalyse. Paris : Seuil, 1965.

MCKENZIE, John L. Dicionário bíblico. São Paulo: Paulinas, 1983.

METZ, C. Para além da analogia, $A$ análise das imagens - novas perspectivas em comunicação 8, Petrópolis: Vozes, 1973, p. 7-18.

METZ, C. Essais sémiotiques. Paris : Editions Klincksieck Esthéthique, 1977.

MORA, J. Ferrater. Diccionario de filosofia. Barcelona: Editorial Ariel, 1994.

PINTO, Milton J. Semiologia e imagens. In: A encenação dos sentidos - mídia, cultura e política. Rio de Janeiro: Diadorim, 1995. 
VERON, Eliseo. Dictionnaire des idées non reçues. In: Connexions, $\mathrm{n}^{\circ} 27$. Paris: ARIP, 1979, p. 125-142.

VERON, Eliseo. Quand lire c'est faire: l'énonciation dans le discours de la presse. Semiotique II. Paris: IREP, 1985, p. 33-56.

VERON, Eliseo. L'espace de supçon. In: Questions de communication, $\mathrm{n}^{\mathrm{O}} 5$, Louvain-La-Neuve: Cabay, 1982, p. 109-164.

VERON, Eliseo. De l'image sémiologique aux discursivités. In: Hermes, no $13-$ 14. Paris: CNRS Éditions, 1994, p.45-63.

\section{Notas}

${ }^{1}$ Epicúrio mostra em sua Carta a Heródoto que os "ídolos” (imagens) ultrapassam em fineza e sutiliza aos corpos sólidos e possuem igualmente em mais velocidade e mobilidade que eles, de tal modo que nada ou muito pouca coisa detêm sua emissão... As imagens não nos afetam apenas pelo sentido da visão, mas também pela audição e olfato; as sensações experimentadas por estes sentidos são causadas pelas radiações das imagens. MORA, J. Ferrater, Diccionario de filosofia, Barcelona, Editorial Ariel, 1994.

${ }^{2}$ MCKENZIE, John L., Dicionário bíblico, São Paulo, Edições Paulinas, 1983, p. 435.

${ }^{3}$ Idem ibidem, p. 436.

${ }^{4}$ GEOFFROY-SCHNEITER, Berenice, FAYOUM, Paris: Éditions Assouline, 1998.

${ }^{5}$ JOLY, M. Introduction à l'analyse de l'image. Paris: Éditions Nathan, 1994, p. 22.

${ }^{6}$ BARTHES, R. Le système de la mode, Paris : Seuil, 1967.

7"(arte fotográfica) representaria um fato antropológico 'sem brilho' ao mesmo tempo absolutamente novo e definitivamente inultrapassável; pela primeira vez em sua história a humanidade conheceria mensagens sem código; a fotografia não seria, pois, o último termo (melhorado) da grande família das imagens, mas corresponderia a uma mutação capital das economias da informação...É sem dúvida, um importante paradoxo histórico: quanto mais a técnica desenvolve a difusão das informações (especialmente das imagens), mais fornece meios de mascarar o sentido construído sob a aparência do sentido original”. BARTHES, R., «A retórica da imagem», in O óbvio e o obtuso - ensaios críticos III. Rio de Janeiro: Nova Fronteira, 1990, p. 37.

${ }^{8}$ Idem ibidem, p. 36. 
${ }^{9}$ BARTHES, R. La chambre claire - notes sur la photographie. Paris : Éditions de l'Étoile/Gallimard/Le Seuil, 1980, p. 138-139.

${ }^{10}$ Idem ibidem, p. 153.

${ }^{11}$ Ver PINTO, Milton J., "Semiologia e imagens". In: A encenação dos sentidos mídia, cultura e política. Rio de Janeiro: Diadorim, 1995. BARTHES, R. «A retórica da imagem». In: O óbvio e o obtuso - ensaios críticos III. Rio de Janeiro: Nova Fronteira, 1990.

${ }^{12}$ A palavra relais em francês origina-se do verbo relayer, que é formado de re + laier, antigo verbo picard, wallon e lorrain, que se torna verbo relaisser - termo de caça empregado no sentido de "parar a cansaço". Os cães cansados numa caça são substituídos por outros, Donner la relais, quer dizer, lançar os cães. Muito empregado no francês contemporâneo a locução "prendre la relais", que se aplica a uma etapa entre dois pontos, onde uma pessoa serve de intermediário entre os dois. Normalmente, o termo relais adquire o sentido de substituição, sentido encontrado no referido texto de Barthes, avançando o sentido igualmente como complementação entre o verbal e o icônico.

${ }^{13}$ METZ, C. "Para além da analogia". A análise das imagens - novas perspectivas em comunicação 8. Petrópolis: Vozes, 1973.

${ }^{14}$ Idem ibidem.

${ }^{15}$ Idem ibidem.

${ }^{16}$ Idem ibidem, p. 10

${ }^{17}$ VERON, Eliseo. «Dictionnaire des idées non reçues». In: Connexions, no 27, Paris: ARIP, 1979.

${ }^{18}$ KRISTEVA, J. Recherche pour une sémanalyse. Paris: Seuil, 1965.

${ }^{19}$ VERON, E. "Quand lire c'est faire: l'énonciation dans le discours de la presse", Semiotique II. Paris: IREP, 1985.

${ }^{20}$ VERON, E., «Dictionnaire des idées non reçues». In: Connexions, $\mathrm{n}^{\mathrm{o}} 27$. Paris: ARIP, 1979.

${ }^{21}$ Idem ibidem, p. 134.

${ }^{22}$ VERON, E. “L'espace de supçon”. In: Questions de communication, n 5. LouvainLa-Neuve: Cabay, 1982.

${ }^{23}$ Tipos da relação texto-imagem sistematizada por Veron: equivalência retórica orientada, equivalência de retórica com identificação, emprego de metáfora visual.

24 “Querer fazer uma 'semiologia da imagem' ou uma 'semiótica visual' (ver nem mais nem menos que uma 'semiótica do mundo natural', para retomar a expressão extrema de Greimas) é um pouco como se propusesse fazer uma semiótica do texto impresso. A universalidade suposta de uma teoria lingüística foi abusivamente transferida sobre objetos 
que não são separáveis de práticas sociais específicas. Esta transferência,alimentada por uma ambição um pouco ingênua, não teve sucesso."VERON, E., "De l'image sémiologique aux discursivités”, In: Hermes, no 13-14. Paris: CNRS Éditions, 1994.

${ }^{25}$ Idem ibidem, p. 56.

${ }^{26}$ Idem ibidem, p. 58. 



\section{O receptor em questão}

Notas sobre as contribuições da análise de discursos para a teoria da comunicação

João José de Santana Borges

Já faz algum tempo, cerca de seis semestres, que venho ensinando a disciplina Teoria da Comunicação. Como percepção geral, os alunos mostram-se não raro resistentes à dinâmica, nada "dinâmica", das aulas rotineiras, em que o docente esforça-se de modo hercúleo para conduzir os intrépidos ouvintes a uma "elevação espiritual", qual seja, a de romper com o pensamento fragmentado dado aos zappings e vôos de borboleta, e introduzir um modo de pensar tenso e profundo com o intuito de compreender os fenômenos da comunicação que os teóricos tentam compreender. A atmosfera da sala raramente é propícia para uma discussão séria, ponderada, atenta ao uso que se faz dos termos, atenta à forma como se desenvolvem os discursos, como se percorrem os torvelinhos, nas encruzilhadas do labirinto do saber.

A primeira constatação é a de que, nem em condições ideais, a disciplina não se esgotaria em um semestre, tal a sua amplitude, e o seu desenvolvi- 
mento contínuo e multifacetado. Se é dada alguma ênfase aos estudos iniciais da sociedade de massa, seguindo o roteiro de Mauro Wolf, é porque ele se apresenta para nós como paradigmático e mesmo originário: indispensável para compor uma certa linearidade histórica das teorias, ainda que o aparente hermetismo do texto de Wolf assuste e entedie os alunos.

Pretendo, neste texto, apresentar um inventário das leituras de autores que circulam no campo teórico da comunicação, com o intuito final de transportar tais leituras para um terreno que não lhe é próprio: o da relação entre os alunos e a disciplina Teoria da comunicação.

A perspectiva aberta por essa disciplina fez-me pensar, com maior cuidado, acerca da questão: se as chamadas teorias da comunicação estão em constante mudança, se o seu campo é tão vasto, como dar conta de sua amplitude em apenas um semestre? Devido ao pouco tempo e a abrangência do conteúdo, o que é essencial e o que pode ser deixado para trás? Longe de fornecer respostas para tal dilema, pretendo neste texto fornecer elementos para melhor formular a questão.

\section{O receptor, objeto e sujeito na cordilheira das abstrações}

Entre o mongolismo e o autismo. Assim Clóvis de Barros Filho identifica, sem dúvida ironicamente, o tratamento dado ao receptor pelas abordagens teóricas da comunicação de massa. De um lado, o receptor é considerado passivo, acrítico, mera caixa vazia. De outro, exagera-se na capacidade de autonomia e defesa perceptual de quem consome os programas midiáticos. 
Entre os dois pólos, uma considerável quantidade de pesquisas tem procurado construir sua especificidade e dado sua contribuição para constituir o campo de estudos em comunicação. Este tópico percorre algumas linhas de trabalho das teorias da comunicação, com ênfase na concepção que cada abordagem faz da figura do receptor. Em seguida, focaliza algumas contribuições da análise de discursos à evolução deste pólo das pesquisas em comunicação (para usar uma imagem cujo uso surpreende, por ser atualizado e ainda recorrente, no entendimento pelos alunos do processo comunicativo: o pólo emissor e o pólo receptor são dois elementos distantes, ligados pelo canal, através da mensagem, no uso de um código).

Se a ciência evolui, e em particular, se as ciências sociais aplicadas evoluem, essa evolução se dá de forma elíptica. Ao propor trabalhos que tenham a difícil proposta de sistematizar os avanços obtidos por determinada disciplina, convém estar alerta quanto aos riscos que Bernard Miège (2000) denuncia, ao avaliar as características de algumas teorias "gerais" da comunicação: o reducionismo, a abstração, a confusão das instâncias consideradas, a divagação futurológica, a ausência de verificação empírica e, sobretudo: "A importância atribuída a um paradigma único assim, entre outras, a pragmática ou certas teorias lingüísticas que se limitam a levar em consideração \{apenas\} a abordagem da comunicação que propõem" (MIÈGE, 2000, 103).

A escolha consciente entre a construção da especificidade sob o risco do reducionismo - e a abertura para uma interdisciplinaridade - que pode perder o foco e o rigor apropriados - de uma área de estudos parece constituir um problema crucial no avançar dessa área, em termos de acúmulo de conhecimento e amplitude metodológica, sobretudo quando aponta para uma proximidade do território da recepção. Pro- 
blema cujo tratamento adequado não pode de longe ser aqui ambicionada. Não é de todo inútil, no entanto, perceber como cada autor convocado parece tratar a questão.

Mauro Wolf elabora um importante trabalho ao inventariar as teorias da comunicação de massa, em um livro ${ }^{1}$ que, apesar de ter sido recentemente editado no Brasil, a edição portuguesa constitui um manual de consulta quase obrigatório na disciplina Teorias da comunicação.

Para ilustrar as concepções paradigmáticas acerca do receptor, faz-se útil mencionar o capítulo denominado "contextos e paradigmas da comunicação de massa". Primeiramente, a teoria hipodérmica ou da bala mágica, por razões históricas e por ser formulada a partir do conceito de sociedade de massa e do modelo comunicativo inspirado no behaviorismo, concebe o receptor como mera "caixa vazia", pertencente a uma massa homogênea de indivíduos passivos, acríticos e atomizados. Isso explica a adesão dos cidadãos à ideologia nazista no período entre guerras (WOLF, 2003).

O conjunto de abordagens empíricas, definidas por Mauro Wolf como empírico-experimental e empírica de campo, também formulam um modelo de receptor, adequado aos seus próprios axiomas. Por tratar-se de um estudo com enfoque psicológico, a abordagem empírico experimental focaliza o indivíduo receptor como sujeito a uma campanha de persuasão, a uma mensagem cuja aceitação dependerá de fatores psicológicos ligados à audiência e à própria mensagem.

A abordagem empírica de campo, por seu turno, advoga uma concepção de receptor vinculado aos grupos sociais, e através da formulação do modelo "two-step flow", pretende estuda-lo levando em conta variáveis sociológicas, o contexto social, bem como a influência dos chamados líderes de opinião. A corrente 
dos usos e gratificações, variante da teoria funcionalista, parece inovar invertendo a questão de base (o que os meios fazem com os receptores) para o que as pessoas fazem com os meios, conferindo um status ativo ao receptor, atribuindo-lhe exagerado grau de conscientização das satisfações que ele saberia obter da mídia.

A teoria crítica inaugura um momento central no roteiro da disciplina. O efeito que essa etapa espera obter é de um ardente questionamento sobre a condição de sujeito do estudante de comunicação e de como ele se posiciona no campo da indústria cultural que o abrigará como operário, e como ele enfrenta a questão do poder alienante dos mass media. $\mathrm{O}$ incentivo à descoberta dos textos dos autores, a perplexidade quanto ao profundo pensar de Adorno e o modo original de Marcuse, servem de um misto de desconforto e contundência, causando em alguns, certo tom panfletário que convém ser remediado pelo agudo ceticismo dos frankfurtianos. $\mathrm{O}$ aluno aqui se vê como receptor; e ao receptor pouco é dado, além da nostalgia da perda de sua condição de sujeito: “o consumidor não é rei [...] ele sofre as imposições da Indústria Cultural sem saber que as sofre." Lê-se em um dos textos de Adorno. De qualquer modo, não há muitas inovações no que diz respeito às concepções habituais de recepção. E essa generalidade abstrata das teorias, guardadas às suas devidas especificidades epistêmicas, permite que seu estudo seja deslocado de contextos de origem e passem a ser adotados em outros territórios. Se a centralidade desses estudos encontra-se no eixo explicativo das duas grandes guerras mundiais, o que é essa centralidade tem a ver de mais íntimo conosco? Por que consideramos essas teorias tão pertinentes ao nosso cenário brasileiro? Por acaso, importamos as teorias porque nos faltam aportes teóricos próprios? Essas questões esbarram em tabus 
paradigmáticos, talvez, e por isso não nos vale aqui enfrentalos. Continuemos, pois.

O fato é que tal inventário permite certas simplificações que agrupam tais teorias (ou fragmentos das mesmas), a partir dos modelos de recepção por elas tematizados: assim, manipulação, persuasão, influência, função, alienação passam a constituir palavraschave para referi-las: da teoria hipodérmica à abordagem empírica de campo, e mesmo em certas leituras parciais da Escola de Frankfurt (quando se desacredita a capacidade crítica da audiência), o receptor mediático carece do status de sujeito; parece ser, grosso modo, reificado, produto de uma abstração cuja concretude é esboçada apenas nas pesquisas empíricas financiadas para fins de expansão do consumo. O que, aliás, tornar-se-á alvo de crítica quando estará em questão a própria razão de ser da ciência ${ }^{2}$.

Em um sentido irônico, e correndo o risco de parecer grosseiro, a constatação de Clóvis de Barros Filho é adequada para conferir um tom de síntese a esses estudos: o receptor é um espectro. Um indivíduo ou grupo que oscila entre a completa passividade e a mais inusitada independência: da plena aceitação acrítica dos conteúdos e significados propostos pelos mass media até o uso anárquico e original, independente do sentido imposto pela mídia. (BARROS FILHO, 2001).

\section{Outras respostas}

Para relativizar a impressão causada pelo tópico acima (quiçá riunda de uma visão distorcida e avessa às particularidades dos estudos em questão), convém lembrar que Mauro Wolf elenca, alhures, outros elementos que enriquecem ou revelam a rique- 
za das teorias acerca da recepção. Em "El análisis de la recepción y la investigación sobre los medios", Wolf faz referência ao conceito de comunidades de interpretação, em que participantes compartilham experiências, em que uma organização social se forma a partir do consumo dos meios. $\mathrm{O}$ aprofundamento de tais estudos leva-nos, ao ver de Mauro Wolf, a desconfiar cada vez mais do poder de influência atribuído aos meios pelas teorias gerais.

O autor recorre aos conceitos de influências cognitivas, memória e esquema para evidenciar a importância de trabalhos empíricos na abordagem da recepção. No entanto, Wolf também procura chamar a atenção para o desafio metodológico no tratamento empírico, que consiste em dar visibilidade à tomada de consciência da realidade social por parte dos receptores. É preciso que haja uma evolução contínua das técnicas de investigação porque os discursos dos receptores sobre este processo - tomados por entrevistas e questionários - não são suficientes para validar tais análises.

Del mismo modo que los datos cuantitativos no nos dicen casi nada acerca de las dimensiones socialmente importantes de los procesos de recepción, el empleo de entrevistas y de cuestionarios no alcanza para dar cuenta de su complejidad.(WOLF, 334)

Nas pesquisas de comunicação, mesmo naquelas não voltadas diretamente para o problema da recepção, os receptores costumam ser abordados com diferentes enfoques: indivíduo isolado, consumidor, cidadão, pertencente a grupos e comunidades, formadores de públicos aos quais se destinam as mensagens dos formadores de opinião, estatísticas, números, abstrações. Também, como veremos: usuários, leitor empírico, leitor modelo, intérprete. Impossível esgotar tal lista de nomeações. Exaustivo seria fornecer aqui o endereço teórico de 
cada uma dessas denominações, analisando as implicações de tais modelos para a problemática geral da comunicação. Umberto Eco se propõe uma tarefa semelhante, embora mais abrangente e completa.

Em Os limites da interpretação, Umberto Eco (1990) expõe, de forma bastante sistemática, a mudança de paradigma que ocorre nas tradições de análises da interpretação, evidenciando uma gradual transição de um formalismo estruturalista para uma pragmática da leitura, em que o receptor passa a ser objeto de atenção privilegiado das teorias da interpretação. Neste texto, ele constrói uma arqueologia remota das diversas abordagens da recepção, da estética, passando pela hermenêutica, à semiótica, bem como uma discussão sobre pragmática do sentido. Das diversas lições que podemos extrair de seu trabalho, podemos destacar as relações entre intention autoris, intentio operis e intentio lectoris por ele tematizadas.

Eco conclui que, em sua posição atual, apontada como conservadora por alguns, a intenção da obra determina a intenção do leitor: da primeira depende o princípio de interpretância; é preciso defender o sentido literal do texto; o leitor não tem tanta liberdade como supõe alguns, no seu exercício oscilante, entre uma leitura semântica e uma leitura crítica, entre uma má leitura e um uso do texto para além (ou aquém) da interpretação.

De todo modo, a impressão que se tem é de tratar-se, em boa parte dos momentos do capítulo, de um leitor privilegiado, ainda que haja a célebre distinção entre leitor-modelo (construído pelo texto) e o leitor-empírico (pouco interessante, salvo em perspectivas sociológicas). Essa impressão é reforçada sobretudo pela maioria dos exemplos por Eco tratados: em certa medida, são textos narrativos e ficcionais, oriundos da literatura. De que modo as categorias tão cuidadosa- 
mente lapidadas podem ser utilizadas em análises de receptores de suportes mediáticos, como, por exemplo, a TV aberta? Essa realidade não é abordada por Eco, pelo menos no capítulo aqui referido, "apontamentos sobre a semiótica da recepção". Encontramos em Eliseo Verón, autor latino-americano, algumas lúcidas considerações a respeito de uma temática aproximada. Segundo Verón, a constituição da prática de leitura enquanto objeto de conhecimento teve que enfrentar alguns obstáculos. A insistência da lingüística em manter a indistinção entre locutor e destinatário (mais um modo de nomear o receptor), em privilegiar a fala em detrimento à escrita, constitui um destes. Além disso,

a semiologia interessou-se sobretudo nas(sic) obras literárias, ou seja, aos textos considerados como excepcionais e portanto automaticamente valorizados: fascinados pela obra (e, através dela, pelo escritor), o semiólogo não está interessado naquele que a lê, e muito menos naquele que não a lê. (VERÓN, 3).

Também a sociologia pouco se interessou pelo funcionamento social dos textos, limitando-se a mapear o receptor em categorias sociológicas, conhecendo os estilos de vida, os objetivos, necessidades e interesses, e outras práticas culturais para além da leitura. De um lado, análise de conteúdo. Do outro, análise da audiência. Dois trabalhos empíricos que pouco dialogam entre si. Véron passa a apontar os limites dessas abordagens, focalizando a atenção em questões pragmáticas que giram em torno do êxito ou fracasso de produtos mediáticos, chamados de suportes. Passa então a desenvolver o conceito de contrato de leitura para dar conta de explicar tais fenômenos, procurando base na teoria da enunciação, para a qual o conteúdo não é a parte mais importante no funcionamento de um contrato de leitura. 
O trabalho de Verón é bastante extenso e mereceria uma leitura mais aprofundada e exclusiva. O nosso propósito aqui é o de apenas sinalizar questões úteis para compor essa tessitura de abordagens da recepção. Ademais, valeria a pena constituir um curso que pudesse dar conta do longo alcance das importantes contribuições de Eliseo Verón, que, a despeito de sua densidade e amplitude temática, não tem sido muito referenciado nos chamados "manuais" de teorias da comunicação (como o já citado anteriormente).

Uma das contribuições da Análise de Discursos para a compreensão do problema aqui colocadoé dada pelar pode ser representada pela noção peirceana de interpretante. Verón utiliza essa noção em seu artigo recentemente publicado ${ }^{3}$, mas como não define o que se está considerando como interpretante (levando talvez demasiado a sério as competências interpretativas de seus leitores), acaba por sugerir algumas discrepâncias, ocasionando confusão, ignorando talvez "os conselhos" de Peirce em seu artigo Como tornar claras as nossas idéias (1984). Interpretante tem o sentido geral de efeito produzido pelo signo na mente do intérprete. Assim como o signo é mediador entre o objeto e o intérprete, o interpretante é mediador entre o signo e a mente que interpreta.

Mas a noção que gostaríamos de utilizar para construir a hipótese já mencionada é a de interpretante imediato. Peirce divide o interpretante em três tipos: interpretante imediato, dinâmico e final. De modo simplificado, pode-se dizer que o interpretante imediato consiste no efeito potencial que o signo pode causar. $\mathrm{O}$ interpretante dinâmico implica na atualização, portanto no efeito real do signo, no que ele efetivamente provoca quando encontra a mente do intérprete (tomado aqui não como indivíduo, mas como modelo de usuário individual 
ou coletivo do signo). A noção de interpretante final, por sua vez, sugere aquilo que o signo pode produzir se levado às últimas conseqüências, confirmando o poder infinito de significar que o signo dispõe.

Tais conceitos, oriundos de uma arquitetura filosófica própria, aqui podem ser referidos para abordar as diversas concepções de receptor que estão sendo examinadas. Os estudos de recepção, tomados em seu conjunto, parecem indicar um certo domínio sobre o interpretante imediato - o que as notícias, os produtos mediáticos diversos - têm em sua estrutura, ou em seu contrato, que indiquem: a resposta (estímulo-resposta), o efeito, o entendimento, a fidelidade, a aquisição que o receptor poderá ter.

A outra idéia consiste em problematizar a condição de sujeito do receptor. Sabe-se que os estudos sobre mídia e política, ainda quando se apropriam da análise de discursos para serem desenvolvidos, privilegiam as investigações em torno dos agentes políticos já legitimados, em geral, tematizando os candidatos enquanto produto, o espetáculo das eleições, abordagens fenomenológicas das relações entre mídia e política, para citar alguns temas recorrentes (LIMA, 2001; FAUSTO NETO, 2003; GOMES, 2004 et ali). Pouco é dado ao sujeito ocultado pelas já hierarquizadas e hierarquizantes posições de poder. $\mathrm{O}$ receptor é figura ausente dos estudos em mídia e política.

Em Contrato de comunicação da informação midiática, Patrick Charaudeau (1994), sinaliza para a instância do contrato de comunicação em que estão localizados os atores sociais: aqueles que se movem nos espaços da democracia que as mídias são forçadas a gerar. Temos,neste grupo: os eleitos e os quais a mídia concede a palavra (espaço da democracia política); os cidadãos que dispõem da palavra midiática por representar os 
diversos grupos de pressão, as pessoas na rua que "estão no direito de opinar sobre a organização da vida da cidade, especialistas que comentam o acontecimento (espaço da democracia civil); as testemunhas, ou atores de fatos "relativos a vida social vista através do seu cotidiano" - as mídias concedem-lhes a palavra em cena mais ou menos catastrófica.

Estes são os sujeitos usuais da fala midiática. Como destacalos deste vasto solo da recepção? Suas aparições na mídia, ainda que esporádicas e transitórias, sinalizam para uma manifestação sinuosa e prenhe de interstícios dos atores sociais aqui chamados de cidadãos. São eles que participam da vida na polis. Aqui, como alhures, o receptor costuma ser identificado como alvo para o qual convergem as estratégias discursivas que visam selar contratos. Como atingir o alvo? Como seduzi-lo? Assim, diz Charedeau, a mídia deverá aplicar a repetição e dramatização, credibilidade, personificação dos eleitos, o testemunho, a ilusão do contato, os efeitos de verdade, os efeitos de ludismo.

O último autor a ser aqui convocado é Teun van Djik. Em Da gramática do texto à análise crítica do discurso, Van Djik (1997) procura relatar o contato com a psicologia cognitivista e como esse contato alterou profundamente as suas antigas incursões na gramática do texto, aproximando-o ainda mais do território da recepção, entendido, no entanto, como composto pelo conjunto dos usuários da linguagem. A noção de entendimento estratégico é um importante caminho de aproximação, visto que procura explicar de maneira mais realista o que "fazem realmente os usuários da linguagem quanto entendem um texto"(VAN DIJK, 1997, 122).Tais usuários passam a ser vistos como mais "flexíveis" e "falíveis", do que a análise das macroestruturas permite prever. 
Também diferente das gramáticas, os usuários da linguagem podem usar informação do texto e o contexto ao mesmo tempo, ou operar em vários níveis do texto (fonológico, sintático, semântico, pragmático) ao mesmo tempo para interpretar o texto. Resumindo, o processamento real do texto é muito diferente da análise formal, estrutural do texto (VANDJIK, 1997, 122).

Memória a curto prazo, memória a longo prazo também constituem categorias importantes para compreender os modos de entendimento do texto pelo usuário. A tais categorias, o autor acrescenta o conhecimento: as pessoas organizam seu conhecimento sócio-cultural do mundo, e para entender um texto, ativam guias - modos abstratos de organização - e usam a informação.

Também a noção de "modelo" foi relevante para definir os graus de coerência textual, uma vez que, a partir das macroestruturas, os usuários constroem modelos de texto e modelos de fatos presentes no texto. "O que as pessoas recordam de um texto não é tanto o seu significado, e sim o modelo que constroem sobre o fato do qual o texto trata". E mais: "Entender um texto significa que somos capazes de construir um modelo mental para o texto." (VAN DIJK, 1997, 124). Associando aos modelos de texto, e ainda a partir de experimentos da psicologia cognitiva, o autor passa a tematizar os modelos de contexto: os usuários também constroem respresentações subjetivas de si mesmo, dos demais participantes, de suas relações sociais, de lugar e tempo, nas situações de comunicação em que se vêem envolvidos.

Todavia, tais estudos ainda se referem ao caráter individual da recepção. Van Dijk também procura alcançar as cognições sociais envolvidas no entendimento do texto: as representações e modelos partilhados socialmente, através de um conceito deveras problemático - o da ideologia. 
Sem abandonar sua principal categoria - a noção de macroestruturas, Van Dijk, passa a enveredar pela disciplina que se preocupa não com a forma (sintaxe), nem com o significado (semântica), mas com os efeitos, os atos de fala. Passa a definir uma visão própria da Pragmática, especificamente, a pragmática do discurso. Em suas considerações, ele retoma o raciocínio de que as proposições estão sobre as macroproposições, adequando-o aos macro-atos de fala: "o conteúdo proposicional de um macro-ato da fala é tipicamente uma macroproposição.” (126)

Em seu estimulante trabalho sobre o racismo, nota-se: o racismo disseminado nas falas dos europeus brancos quanto aos imigrantes e as minorias de modo geral; o racismo difundido, através de vários modelos, na imprensa européia e ainfluência massiva da imprensa, de seus estereótipos quanto às minorias, nos leitores; o racismo reproduzido - ainda que de modo não declarado em instituições, discursos políticos, escolas e grupos elitizados. "Por isso é que chegamos a conclusão de que a imprensa na Europa joga um rol central para manter (e algumas vezes agravar) o "status étnico" quando não, na reprodução do racismo” (130). Resta-nos indagar qual é a concepção de receptor que parece ser alimentada por esse estudo. Antes de mais nada, a ausência de uma fala própria dos vitimados pelo preconceito nos noticiários - em geral, negativos - a seu respeito, acaba se reproduzindo, ao que parece, na pesquisa. O problema de identidade dos latinos, negros e árabes enquanto receptores ou usuários do discurso da imprensa não parece ter relevância no estudo.

Todavia, o autor refere-se a um importante movimento interno à disciplina da análise de discurso: o do seu potencial crítico, que consiste em orientar-se por temas de pregnância social. A Análise crítica de discurso poderia comprometer-se a in- 
vestigar os discursos sociais, servindo mais àqueles que necessitam do que os que "podem pagar melhor".

A ACD deste modo, está tornando-se um movimento de investigadores que prestam maior atenção aos que mais necessitam aos problemas sociais que com os paradigmas acadêmicos, e em geral, estudam as muitas formas de (abuso) de poder nas relações de gênero, étnicas, e de classes tais como o sexismo e o racismo. Querem saber como o discurso atua, expressa, perdoa ou contribui para a reprodução da desigualdade. Ao mesmo tempo, esses pesquisadores escutam as experiências e as opiniões dos grupos dominados, e estudam os modos mais efetivos de resistência e contradição. (ibidem, p.134)

\section{Consideraçōes finais}

Enveredar por essa preocupação contextualizante do discurso implica, a nosso ver, no diálogo com outras tradições da teoria da comunicação. Vislumbra-se neste encontro um impasse: a análise de discurso perderia assim o seu estatuto de disciplina? Tornar-se-ia uma metodologia a ser aplicada com interesses diversos do que se propunha? Deixaria de ser um fim em si mesmo - com a excessiva preocupação com os paradigmas acadêmicos - e serviria para atingir objetivos que extrapolam o rigor da análise?

Essa expansão de corpus não se daria sem danos aos analistas "por profissão". O próprio van Dijk já adverte quanto ao caráter multidisciplinar da análise de discursos. Advoga por uma integração e as visitas por outros campos, uma vez que é desse "desprendimento" que surgem novos problemas e novas teorias para deles dar conta. 
O desafio aqui deixado consistiria em fazer uso das categorias da Análise de Discursos para compreender o processo interpretativo dos alunos face às disciplina teóricas: uma solução, talvez simplista, porém necessária para sanar o tom de abstração que o termo "receptor" tem para nós, quando não o enfrentamos no terreno empírico.

Tomar os alunos de Teorias da Comunicação como receptores, além de midiáticos, do nosso discurso, remete-nos à célebre discussão sobre a rationale científica das Ciências sociais: qual seria o papel de uma ciência da análise dos discursos ? Ou mais amplamente, qual seria o papel do estudo das teorias da comunicação?

Como últimas palavras que, sem propor um fechamento para as questões, convida para uma nova abertura, lembremos dos postulados de Marcuse acerca da Teoria Social Crítica:

Ojulgamento de que a vida humana vale a pena ser vivida, ou melhor, pode ser ou deve ser tornada digna de se viver. Este julgamento alicerça todo esforço intelectual. [...] $\mathrm{O}$ julgamento de que, em determinada sociedade, existem possibilidades específicas de melhorar a vida humana [...]A análise crítica tem de demonstrar a validez objetiva desses julgamentos, tendo a demonstração de se processar em bases empíricas. (MARCUSE, 1978, p. 15)

\section{Notas}

${ }^{1}$ Refiro-me à obra Teorias das comunicações de massa, editada pela Martins Fontes (2003).

${ }^{2}$ Ver debate entre Habermas e um dos positivistas, tratado por Freitag (1988) em A teoria crítica:ontem e hoje.

3 “Televisão e política: história da televisão e campanhas presidenciais" 


\section{Referências}

BARROS FILHO, Clóvis de. O habitus na comunicação. São Paulo: Paulus, 2003.

CHARAUDEAU, Patrick. Contrato de comunicação da informação midiática. Paris: Edicef, 1994 (julho).

DIJK, Teun van. Racismo y análisis crítico de los médios. Barcelona: Ediciones Piados, 1997.

ECO, Umberto. Os limites da interpretação. São Paulo: Editora Perspectiva, 1990.

FAUSTO NETO, Antônio. (org). Lula Presidente: televisão e política na campanha eleitoral. Leopoldo, RS: Unisinos, 2003.

GOMES, Wilson. Transformações da política na era da comunicação de massa. São Paulo: Paulus, 2004.

PEIRCE, Charles Sanders. Semiótica e Filosofia. São Paulo: Editora Cultrix, 1984

SANTAELLA, Lucia. Teoria geral dos signos. São Paulo: Editora Pioneira, 2000.

VERÓN, Eliseu. A análise do "contrato de leitura". Paris: IREO, 1983.

WOLF, Mauro. El análisis de la recepción y la investigación sobre los medios. In: Recherche en communication et analýse textuelle. Hermes. Paris: CNRS Éditions.

WOLF, Mauro. Teorias das comunicações de massa. São Paulo: Martins Fontes, 2003. 



\section{A arte sutil da tipografia}

Matilde Eugênia Schnitman

\section{Introdução}

Desde os primórdios, a representação grafada está relacionada às técnicas de cada época. $\mathrm{Na}$ arte rupestre é possível acompanhar a evolução do modus faciendi a partir do desenho, inicialmente em paredes de cavernas, possivelmente utilizando materiais encontrados na natureza ou mesmo o carvão. Posteriormente, já no neolítico, são gravações em pedra, indicando o uso de pedras mais resistentes ou objetos de metal. A relação do modo de fazer com a representação grafada pode ser observada inclusive na evolução do desenho das letras do alfabeto, neste caso o alfabeto romano, objeto desta análise, que deu origem a várias grafias no mundo ocidental.

Desvendar esta relação é o objetivo deste trabalho sem pretender ser conclusivo, nem tampouco explorar ou interpretar a representação grafada desde os primórdios. A questão que orienta a aborda- 
gem decorre do fato de reconhecer hoje a importância do alfabeto para o pensamento humano e de estarmos observando novos modos de comunicação grafada, uma possível nova escrita, talvez uma linguagem mundial baseada em pictogramas a partir de elementos gráficos presentes na maioria dos teclados, periféricos de computadores que adotam padrões internacionais.

Para percorrer os caminhos da representação grafada e sua relação com as técnicas de cada época, adotou-se o conceito de LINGUAGEM VISÍvEL para tipografia:

Conjunto de práticas subjacentes a criação e utilização de símbolos visíveis relacionados aos caracteres ortográficos (letras) e para-ortográficos (tais como números e sinais de pontuação) para fins de reprodução, independentemente do modo como foram criados (a mão livre, por meios mecânicos) ou reproduzidos (impressos em papel, gravados em um documento digital). (FARIAS, 1998, p. 11)

Por sua vez, ARTE é aqui entendida como registrada no dicionário Michaelis nas acepções: 4. Execução prática de uma idéia. 5. Saber ou perícia em empregar os meios para conseguir um resultado. Especialmente a quinta acepção leva a uma das preocupações que norteiam este trabalho, na medida em que a tecnologia disponibiliza novos e revolucionários meios de se obter resultados, de executar uma idéia. Por conseqüência, exige a retomada da arte na primeira acepção registrada no dicionário citado: conjunto de regras para fazer ou dizer alguma coisa.

\section{A tipografia romana}

O domínio do Império Romano, cristão, por praticamente todo o entorno do mediterrâneo marcou profundamente a cultura 
ocidental. Não por outro motivo vem de Roma a definição do conjunto de letras que compõem o alfabeto, o padrão visual da escrita e a estética ocidental. Uma das características marcantes da arquitetura clássica romana são as cúpulas arredondadas e as inscrições em pedra. Especialmente nas inscrições em pedra, não é difícil identificar a relação entre o resultado e o modo de fazer: a grafia em lápides exigia traços retos e angulosos. As lapidares - grafadas em pedra - deram origem às letras maiúsculas do alfabeto romano e é possível que as minúsculas de traços arredondados, grafadas em pergaminho e papel, reflitam as cúpulas arredondadas que caracterizam a arquitetura romana.

\section{CORNELIVS:L VS.SCIPIC.BAR TVS.CNAIVO}

Romana inicial - Séc. II a.C

\section{MATRONIS. FLIABVS.M.}

Capitais Monumentais - séc. I d.C.

Dão origem às maiúscula

\section{Equiciomn fícantequa GTNONTËITN}

Uncial e semi-uncial - séc. III

Dão origem às minúsculas

Com a queda do Império Romano, rompe-se a uniformidade da língua e da escrita no mundo ocidental. Surgem as primeiras línguas nacionais e os signos da escrita perdem a estabilida- 
de, refletindo quebra dos paradigmas vigentes, como se pode observar na escrita Merovíngia (Séc. VII - VIII).

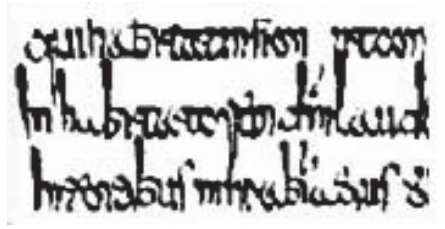

Ao ser coroado pelo papa Leão III, no início do Sacro Império Romano Germânico (séc. VIII-XIX), Carlos Magno tenta restaurar as instituições e a força política do Império Romano e busca a unificação da escrita a partir dos modelos e formas usadas na antiguidade clássica.

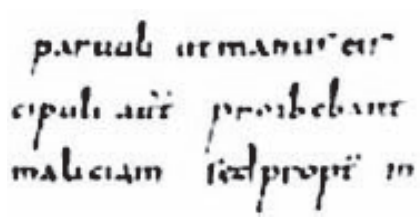

Carolíngia

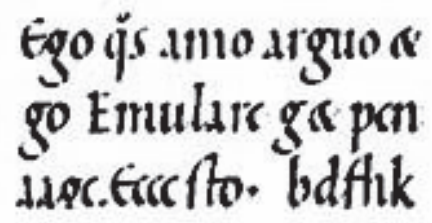

Carolíngia tardia

O reinado de Carlos Magno, segundo Burns (1974), caracteriza-se por uma espécie de renascimento das letras e das artes na Europa Ocidental por causa do enérgico impulso doimperador. Alcuíno de York é o diretor da escola instalada no próprio palácio de Carlos Magno. A partir dali, Alcuíno exerce uma grande influência sobre o movimento teológico, científico e literário da época. Para Burns, Carlos Magno consolidou as instituições feudo-vassálicas, que prepararam o advento do chamado feudalismo clássico, situado entre os séculos X e XIII. Com o apoio da Igreja às guerras de expansão do 
império e a conversão dos povos dominados ao cristianismo, Carlos Magno dá as bases da cultura feudo-vassálica que adquire pouco a pouco, e a partir de então, uma forma especificamente cristã. Com a morte de Carlos Magno (814) o império, já divido em condados, rapidamente se fragmenta sem, contudo, perder a ligação com Roma, com o cristianismo e com a organização social em condados e ducados promovida por Carlos Magno.

A partir de então, outros padrões estéticos vão surgir com a hegemonia dos povos germânicos que promoveram mudanças arquitetônicas conhecidas como "revolução gótica", nome dado pelos renascentistas para se referir pejorativamente aos godos, um dos povos considerados bárbaros pela cultura romana. Segundo Gombrich (1985), estas mudanças foram determinadas pela necessidade de encontrar soluções técnicas para resolver os problemas de estabilidade das grandes e arredondadas cúpulas romanas, dado que as técnicas de construção não foram recuperadas quando da restauração das instituições romanas por Carlos Magno. O novo modus faciendi originário dos povos habitantes da parte norte ocidental da Europa - os bárbaros - se refletiu nas letras, de início confusas e pouco diferenciadas. Apesar da homogeneização, que dificultava a leitura, do ponto de vista estético as letras góticas, talvez um aperfeiçoamento da escrita merovíngia, formavam páginas densas e com personalidade. Foi este estilo de letra que Gutenberg imitou em seus primeiros tipos, não só por sua descendência germânica, mas possivelmente por se adaptarem melhor à fundição. 


\section{filug atto an

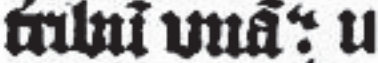 \\ it lucrumat ba}

Gótica

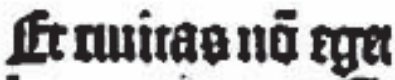 luteant in 8a. IA minabir eamiet li}

Textur - a letra dos livros de Gutenberg

\section{Novos paradigmas - nova visão de mundo}

O Renascimento vai trazer novos paradigmas estéticos e culturais, notadamente o retorno à antiguidade clássica e o humanismo. Não por outro motivo a palavra renascimento foi criada na Itália, indicando o desejo de retorno aos tempos gloriosos de Roma. E é na Itália renascentista que começam a emergir os contornos de uma nova estética, de uma nova visão de mundo.

No Renascimento, as letras de tradição germânica que predominaram nos primeiros livros impressos, são substituídas por letras redondas de tradição romana, chamadas de humanísticas que dão a base do desenho tipográfico ocidental. As Capitais Monumentais, usadas para inscrições em pedra na velha Roma, inspiraram as maiúsculas. A Uncial e a Semi-Uncial, de talhe mais arredondado e usada em documentos, deram origem às minúsculas.

Veneza, centro do comércio mundial à época, é a sede da Academia Aldina, fundada em 1500 por Aldo Manucio, considerado o primeiro editor que não era fundidor. A academia reuniu doutos em literatura clássica que se dedicaram a uma cuidadosa revisão dos melhores manuscritos gregos e romanos antigos com vistas à publicação. As inovações de Manucio na área editorial envolvem a redução do tamanho do livro, criação de 
letras de desenho mais claro e definido e a invenção das letras cursivas, fundidas por Francesco Griffo - que levaram inicialmente o nome de aldina, ficaram conhecidas como grifo, em homenagem ao fundidor, atualmente são chamadas de itálico.

\footnotetext{
A. EME.

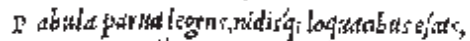

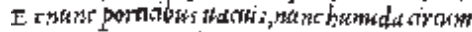

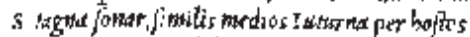

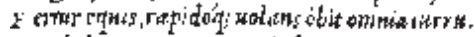

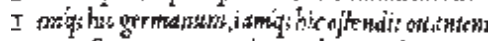

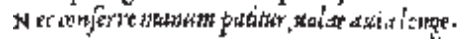

O itálico de Manucio

Hypnerotomachia

\section{cozquatacupactura, quafi diuno ite Ia fragrante \& nigetrima picatura nit. tione, di fyriacoliniamento pertutof tute lealtue circúftancie dıfopra oppo:}

Detalhe do incunábulo de Francesco Colonna,

Poliphi, publicado em 1499, por Manucio.

A quebra dos paradigmas vigentes na idade média deve-se, entre outras coisas, a descobertas e avanços científicos propagados pela imprensa. Esta por sua vez é um dos vetores da formação, ainda que embrionária, dos estados-nação que vão marcar a fase histórica chamada de moderna, na medida em que a imprensa possibilita a emergência e o registro das muitas línguas dos povos europeus.

Libertos da dominação religiosa, os renascentistas implantam um novo modus faciendi, corolário dos avanços na ciência e nas artes, para atender à demanda da urbanização crescente, da formação de mercados. Pouco depois da imprensa, no século XVI, as letras do alfabeto romano assumem o padrão vigente até hoje, padrão que resulta da mecanização e da industrialização, 
esta, por sua vez montada em procedimentos científicos. Devese ainda aos renascentistas a emergência de novas ciências. Segundo Burke (2003), estas ciências, na verdade, eram "conhecimentos alternativos", que foram absorvidos e sistematizados pela comunidade letrada à época.

\section{Sistemas de medidas}

- Vale relembrar que o Renascimento é a época das grandes navegações - uma decorrência da formação de mercados e da necessidade insumos para atender urbanização crescente, esta por sua vez, corolário da demanda por mão de obra para as muitas fábricas que se instalaram no Europa Ocidental. Um dos conhecimentos práticos, ou alternativos, como chama Burke, que começa a ser sistematizado é a Cartografia, profundamente relacionada com as grandes navegações. A Cartografia, por sua vez depende de matemática e esta de unidades de medida. Surgem as primeiras propostas de um sistema de medida unificado não só para atender a Cartografia como também para orientar as trocas comerciais, a estas alturas transoceânicas. Numa perspectiva histórica, poder-se-ia afirmar que a universalização do sistema de medidas e do horário é quase simultânea e ambos estão relacionados e são decorrência da Cartografia, necessária à navegação.

As primeiras tentativas de estabelecer um sistema universal de pesos e medidas datam do final do século XVII (1670), mas a Convenção do Metro só vai acontecer no último quarto do século XIX (1875) em Paris, assinada por 48 países, inclusive o Brasil. A universalização da contagem do tempo tem história 
semelhante à do sistema de pesos e medidas. Até o século XVIII não havia um critério único para medição do tempo, embora a maioria das medidas adotadas tivesse como base nos movimentos do sol, uma herança da cultura egípcia que inspirou o calendário gregoriano, adotado nos países europeus católicos em 1582. Mas só no final do século XIX (1884), uma conferência internacional realizada em Washington determinou um dia universal para o planeta, com início a zero hora GMT (Greenwich Meridian Time).

\section{Medidas gráficas}

- No que tange a tipografia, o desenvolvimento e universalização das medidas gráficas não foi muito diferente. É provável que tenha convivido com outros sistemas, como aconteceu com o sistema de pesos e medidas. O que se pode observar nas pesquisas realizadas é que os primeiros tipógrafos adotaram uma medida, o cícero, possivelmente homenagem ao grande orador romano. E foi a partir do cícero que Pierre Simon Fournier, tipógrafo e gravador francês, criou em 1737, o ponto tipográfico e inventou o tipômetro.

Não é coincidência, portanto, o fato de as medidas tipográficas terem surgido na França, país que propôs a unificação e universalização do sistema de pesos e medidas. O ponto e a escala tipográfica (o tipômetro - 1742) propostos por Fournier tem base no sistema métrico: um cícero corresponde a 12 pontos tipográficos ou 0,34875 mm. Esta medida vai ser aperfeiçoada por Ambroise Didot, também francês, em 1775. 
Estabelecidos os critérios de grafia e as medidas, o desenho das letras se estabiliza, como se estabilizam os novos paradigmas da sociedade ocidental depois da efervescência renascentista. A arte e a tipografia refletem esta estabilidade.

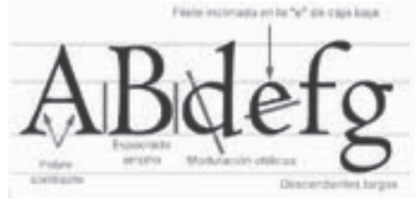

Por ser uma imitação da letra manuscrita romana, os primeiros tipos humanísticos apresentam uma modulação oblíqua, característica da grafia manuscrita, como se pode observar na ilustração. O contraste entre as hastes não é acentuado, a altura das maiúsculas é igual aos traços ascendentes das minúsculas, as serifas são grossas e ligeiramente inclinadas.

Fonte: www.unostiposduros.com. História da Tipografia.

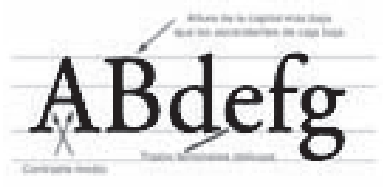

Antigos franceses - 1530

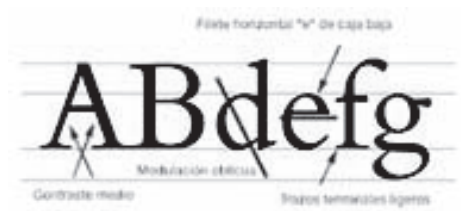

Antigos países baixos (Holanda) $-\sec$ XVII

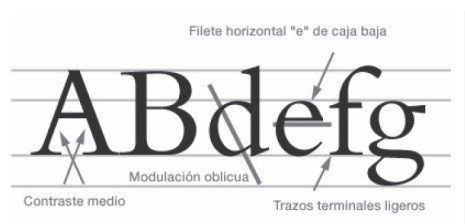

Antigos italianos, Manucio - 1490

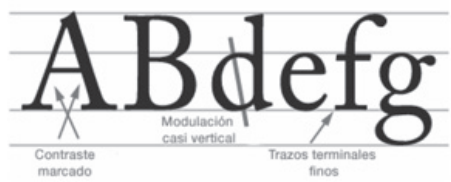

Antigos ingleses - séc XVIII

120 A arte sutil da tipografia 
Como se pode observar, a partir do século XVI, meio século depois de Gutenberg, não há variações de impacto no desenho das letras. São pequenos detalhes que, no conjunto, criam identidade própria, elemento que vai ser buscado intensamente com o avanço da tipografia no mundo. Mesmo os tipos chamados de egípcios tinham as mesmas variações. Surgem no início do século XIX (1817) para atender à publicidade.

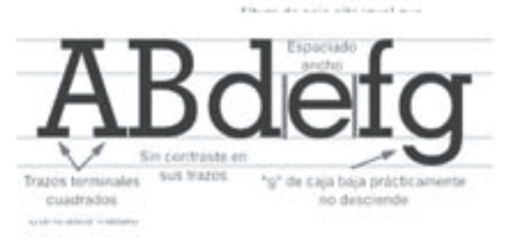

Fonte: www.unostiposduros.com

Não por outro motivo, o professor Juan Val afirma:

A tipografia é uma arte sutil. Baseia-se em pequeníssimas variações aplicadas às formas das letras que foram definidas há mais de dois mil anos. O problema é que uma pequena modificação pode resultar num enorme efeito. Também é uma arte sutil porque os elementos tipográficos se conjugam de uma maneira muito delicada e pequenas alterações nos parâmetros alteram o processo de leitura e a aparência.

http://www.juanval.net/fundamentos_tipometría.htm 


\section{A arte e artes gráficas}

O século XIX dispara a industrialização que vai impactar os valores e a organização social. Segundo Gombrich (1985, p.395), a revolução industrial começou a destruir as próprias tradições do sólido artesanato; o trabalho manual cedia lugar à produção mecânica, a oficina à fábrica. É o século da fotografia, da máquina de escrever, das primeiras máquinas de composição tipográfica (linotipo e monotipo), dos primeiros jornais impressos em rotativas, do telefone, do gramofone, da descoberta e do uso da eletricidade, dos primeiros passos para a fotografia em movimento - o cinema. Da litografia a cores, da xilografia como arte. Da invenção da retícula, a decomposição da imagem em pontos que vai permitir a impressão em tom contínuo. $\mathrm{Na}$ arte, segundo Gombrich, instala-se a revolução permanente. A inspiração clássica não mais satisfaz.

A segunda metade do século vai encontrar Manet, Monet, Renoir, Pissarro, Degas, Rodin que procuravam convenções na pintura que se tinham tornado "cediças e destituídas de significado" (GOMBRICH, 1985, p. 404). Os impressionistas, como ficaram conhecidos, saíram dos ateliês e investiram na paisagem externa, na mistura de matizes que a luz provoca na natureza, ao ar livre, desafiando convenções que pintavam o mundo como ele deveria ser, uma herança medieval que se manteve apesar da descoberta da perspectiva científica, no Renascimento. "O desenvolvimento da máquina fotográfica portátil e do instantâneo ocorreu durante os mesmos anos que também presenciaram a ascensão da pintura impressionista”. (GOMBRICH, idem, p. 416)

Sempre que se observa a quebra de paradigmas e de convenções, percebidos mais rapidamente na arte e na arquitetura, 
observa-se também a busca de novos padrões, tarefa a que se entregou Cézanne. Queria encontrar a solidez, a impecável beleza e a harmonia dos clássicos, apesar de considerar a arte acadêmica contrária à natureza. Queria, segundo Gombrich, reconciliar o sentido da ordem com os métodos impressionistas. Seurat, contemporâneo um pouco mais jovem, também usa os métodos impressionistas associados à teoria científica da visão cromática - a mesma que baseou a invenção da retícula (decomposição da imagem em pontos - ilusão de ótica) - para pintar seus quadros através de pequenos pontos, técnica conhecida como pontilhismo.

No final do século XIX, de industrialização crescente, o declínio geral do artesanato e a crise de paradigmas da arte e da arquitetura clássica eram fatos. A produção em massa desencadeou o que poderíamos chamar um "estilo fabril", ainda que reproduzindo estilos históricos como o clássico romano ou grego. Enquanto uns sonhavam em retroagir quase às condições da arte medieval, outros buscavam experimentar e explorar novos materiais. Na arquitetura, é a fase do ferro e do aço, evidenciada nas grandes estações ferroviárias européias.

A homogeneização de processos e produtos promovida pela industrialização provoca na sociedade a re-valorização do artesanato, possivelmente uma tentativa de recolocar o homem no processo produtivo, a estas alturas totalmente mecanizado. $\mathrm{Na}$ arte, as telas de Van Gogh anunciavam esta angústia. Especialmente em Van Gogh, observa-se o paisagismo bucólico, possivelmente buscando a natureza perdida e a luminosidade ausente nos prédios e no interior das fábricas da magna urbis. Neste sentido, é possível afirmar que, de certa forma, Van Gogh, apesar de impressionista, não aceita o cientificismo proposto por Seurat, a perfeição de Cézanne, a alegria burguesa de Renoir, 
o exotismo de Gauguin e busca uma estética mais humana e menos perfeita que posteriormente, segundo Gombrich, vai dar espaço ao primitivismo.

A desconstrução e a busca de novos de paradigmas nas artes plásticas vai gestar vários movimentos, nenhum deles com vigor para impor um estilo definitivo. Entretanto, o inconformismo em relação à medíocre estética da produção de massa trás de volta o artesanato e dissemina o gosto pelo genuíno, simples e caseiro. Deste inconformismo emerge a Art Nouveau, de forte inspiração artesanal. Fruto do movimento contra a técnica, esta arte foi buscar inspiração no oriente distante, no Japão. Os novos materiais possibilitavam o uso de formas assimétricas, sinuosas de característica naturalista. Esta nova arte, considerada por alguns anti-histórica, inspirou-se também na arte medieval, no barroco e no rococó. Valorizava o decorativo, o ornamental em contraposição à simetria das formas industriais.

\section{Arte e tipografia}

Também nas artes gráficas, a fonte clássica se esgotava. As primeiras décadas do século XIX presenciaram bibliófilos e artesãos da arte do livro desinteressados pela repetição dos motivos inspirados arte romântica usados na encadernação ${ }^{1}$. No miolo do livro, o desenho dos tipos, estabilizado, não oferecia novidades. A tipografia, também amadurecida, começa a se associar com a arte, especialmente a xilogravura, a litogravura e retoma o uso da água forte, do início da imprensa, agora buscando alternativas à mesmice, ao pastiche, trazido, ou mesmo imposto, pela industrialização. 
Na segunda metade do século XIX em diante já se observam livros com ilustrações de artistas famosos, como Renoir, Degas, Beardsley e outros menos conhecidos que, possivelmente, dedicaram sua arte à ilustração de livros, com Louis Legran, Adolphe Lalauze, Edmond Rudax, entre outros (Museu Calouste Gulbenkian, 1997). Além dos encadernadores, que faziam das capas verdadeiras obras de arte. E é exatamente nas capas dos livros que se pode observar a influência dos estilos.

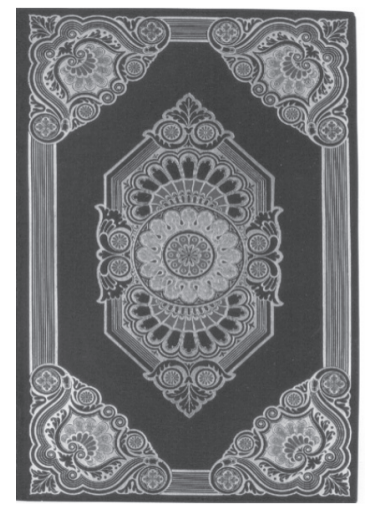

1829 Florōes, arabescos, ramos e folhagens arquitetônicos góticos:

de inspiração romântica. p. 36 e 37, MCG, 1997.

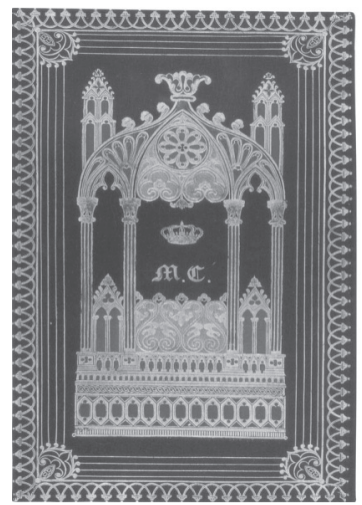

1829 Motivos arquitetônicos góticos: - arcadas, rosáceas, pórticos p. 38-39, MCG, 1997. 


\section{Art Nouveau e Tipografia}

Para Paola L. Fraticola, a art nouveau se constitui historicamente a primeira aliança entre a arte e a indústria. Portanto, é possível afirmar, sem hesitação, que este casamento começou com a indústria gráfica, notadamente na França.

A art nouveau é possivelmente o movimento em que a relação e a influência nas artes gráficas é mais nítida. Segundo Gombrich (1985, p. 426), este movimento estético não podia tolerar livros mal impressos ou ilustrações que meramente contavam uma história sem levar em conta o efeito delas nas páginas. Estudiosos chegam a afirmar que as ruas de Paris se transformaram insólita galeria de arte, pela quantidade de cartazes espalhados em muros e postes de iluminação. E foi a indústria francesa de artes gráficas quem primeiro renovou os caracteres e os materiais de impressão a partir do novo estilo, que passou a ser usado nos mais modestos e nos mais sofisticados impressos: anúncios, convites, marcas de fábricas e de produtos, monogramas, ex-líbris etc. E isto, sem dúvida, permitiu que o novo estilo se disseminasse no imaginário popular.
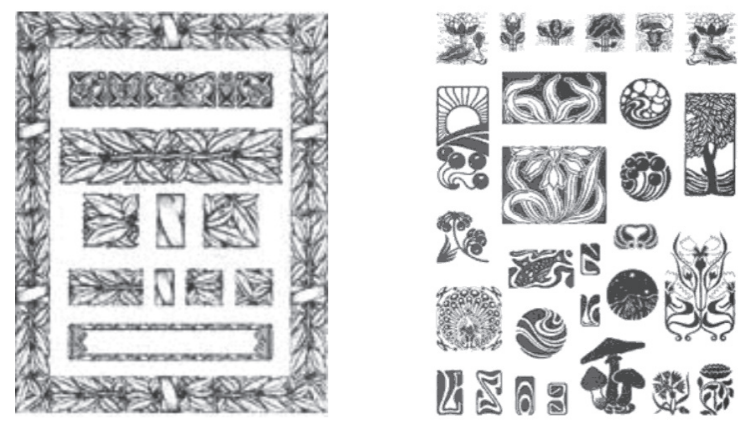

Vinhetas tipográficas no estilo Art Nouveau.

126 A arte sutil da tipografia 


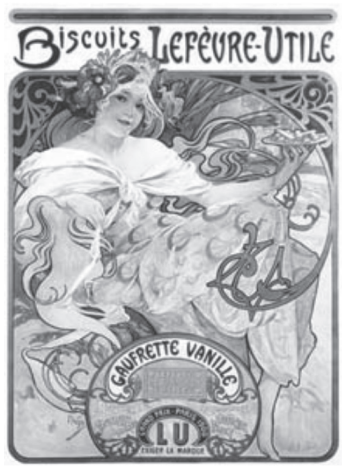

Mucha

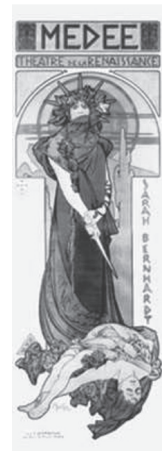

Mucha

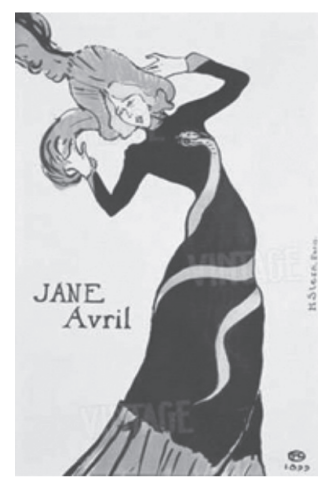

Lautrec

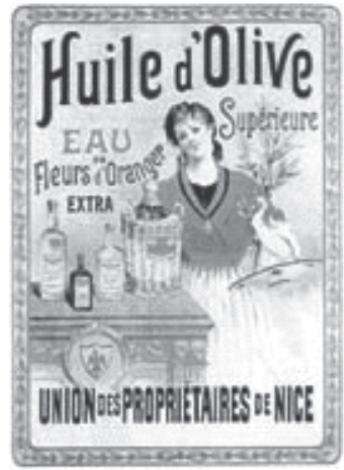

Klimt

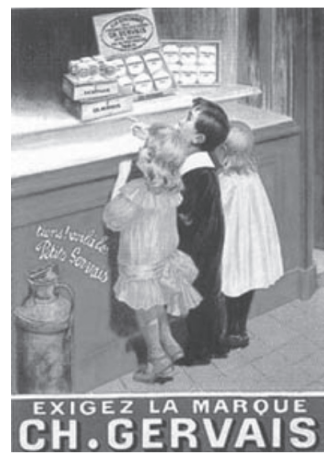

Klimt

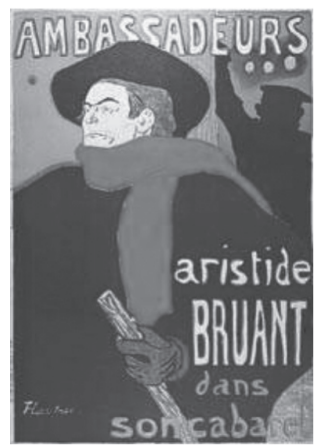

Lautrec 
Nos livros, o estilo assimétrico e sinuoso das letras não se adaptava a fundição de tipos menores nem a grandes blocos de texto por comprometer a legibilidade. Em tamanhos maiores, as gráficas fundiram uma variedade de tipos para usar em títulos e em capas, além do uso já difundido em cartazes, anúncios, marcas etc. Contudo, é a art nouveau que devolve ao miolo dos livros a riqueza de elementos gráficos presente nos manuscritos medievais e perdida com a chegada da imprensa.
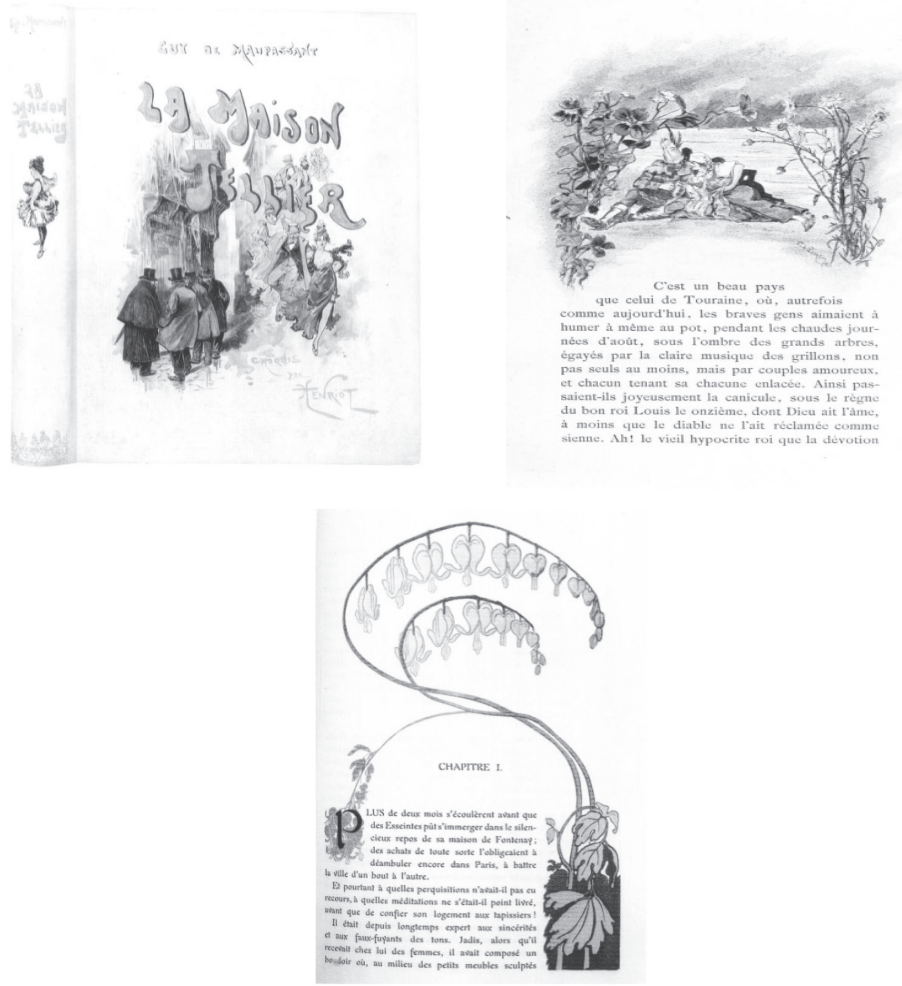

Fonte: Museu Calouste Gulbenkian. O livro objecto de arte. Lisboa, Centro Cultural Calouste Gulbenkian 1997.

128 A arte sutil da tipografia 
Agora apoiada pelo novo e revolucionário processo de impressão indireta inspirado na litografia - o offset, vigente até aqui - art nouveau adentra o século XX. E, do casamento entre arte e indústria, nasce um novo conceito de arte, a arte aplicada - o design.

\section{O século das massas}

O século XX é o século das massas [...] da produção e consumo de massa, da comunicação de massa [...] Nikolaus Previsner. (apud CASTRO, 2004, p.28)

A reboque da mundialização do mercado, entram em cena o rádio e o telégrafo, e com eles a mundialização da guerra. E foi a primeira guerra mundial que, segundo Castro (2004, p. 29) estabeleceu e instalou definitivamente o design reconhecido como elemento educativo e informativo. E foi também a primeira guerra que promoveu um expressivo avanço nos processos produtivos. Entretanto, o que incomodou os artistas no final do século XIX - a mesmice dos produtos fabris - transforma-se em problema para as grandes indústrias. A capacidade produtiva cada vez maior não gerava diferenciais mercadológicos que cativassem o consumidor. A solução vem da arte aplicada, o design, já plenamente absorvida pela industrial editorial gráfica.

Enquanto a arte se debatia em busca de novos estilos, enquanto várias escolas buscavam o sentido da arte em meio à emergência das massas, a arte aplicada, comercial, produzia para as massas explorando novos materiais e técnicas de produção baseada nos avanços científicos. Colocava nos produtos o design, o diferencial mercadológico que as indústrias necessitavam. $\mathrm{Na}$ 
Alemanha, país que sofreu grande revés na primeira guerra, a arte aplicada ganha conotações ideológicas. Walter Gropius, arquiteto alemão envolvido com design gráfico, design de produto e com arquitetura, é um dos fundadores, em 1919, da Escola de Artes, Design e Arquitetura, a Bauhaus, cujo ideal era eliminar as barreiras entre arte, arquitetura e indústria (FARIAS, 1998, p. 20). Esta escola vai influenciar decisivamente a estética do século XX. Para Castro, (2004, p. 30)

Gropius representa o racionalismo e a procura do equilíbrio entre a forma e a função [...] Via na produção em série da sociedade industrial não a banalidade, mas a possibilidade de democratizar a arte e o design.

Fechada pelos nazistas em 1933, exatamente pelo cunho democrático das suas propostas, a Bauhaus deixou sua marca também nas artes gráficas: as letras bastonadas. Estas letras - as grotescas, que surgiram no início do século XIX - foram aperfeiçoadas no decorrer do século e eram utilizadas apenas em anúncios. Poucas apresentavam alfabeto minúsculo, cursivas e versais. Em 1898, Akzidenz, possivelmente por influência dos movimentos na arte que buscavam inspiração gótica e medieval, aperfeiçoa o traço e desenvolve um tipo adaptado ao texto corrido. Entretanto, foi a Bauhaus que fez emergir, definitivamente, as letras bastonadas, criadas a partir de um estilo austero e funcional, adequado não só à impressão offset, como capaz de ser absorvido, posteriormente, pelas técnicas de fotocomposição. São tipos monolineares construídos a partir de linhas retas e figuras geométricas básicas como o círculo e o retângulo. A Futura, no início fortemente associada ao ideário da esquerda mundial, foi desenhada por Paul Renner em 1928, é considerada símbolo da Bauhaus e se tornou popular em publicações educativas e infantis. 


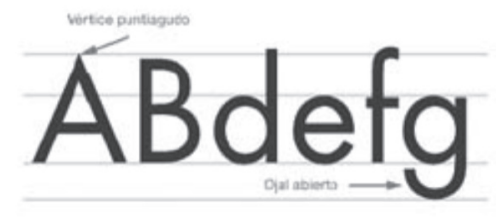

Da perspectiva industrial, com a disseminação do uso da eletricidade e com o grande avanço tecnológico, o século XX enterra a fundição de tipos para impressão. Os tipos bastonados respondem bem ao novo processo de composição das páginas, a fotocomposição, que se dissemina a partir da segunda guerra mundial. A partir de então as letras bastonadas entram definitivamente no universo da tipografia. Timidamente no início, mas hoje dividindo o espaço com as redondas serifadas de tradição romana, sem rivalizar com a Times New Roman, a letra mais usada no século XX.

\section{Antes e depois da guerra}

O século que inaugura o massacre, a "era dos extremos", como Hobsbawm (1995) nomeia o século XX, é também marcado por um acelerado desenvolvimento científico e tecnológico. O século que muda a base energética do mundo, do carvão para o petróleo, que desloca da Europa para a EUA o eixo artístico, científico e cultural. O nazismo, ainda segundo Gombrich, baniu a arte moderna e os líderes do movimento foram exilados ou proibidos de trabalhar. Como baniu também intelectuais e cientistas que emigraram, muitos, para a "América".

A arte depois da segunda guerra é caracterizada por Gombrich como "arte experimental". E sob esta tarja estão o cubismo, o minimalismo, o primitivismo, o abstracionismo, fauvismo e 
outros movimentos que nos legaram artistas europeus como Picasso, Kadinsky, Paul Klee, Chagall, Mondrian, Dali, entre muitos outros. Prenunciando o caos que se instalaria na sociedade ocidental do pós-guerra, não só pela morte e pelo desterro de centenas de milhares de famílias, como assinala Hobsbawm, mas também pelo impacto do desenvolvimento tecnológico, emerge o americano Pollock e sua "pintura de ação", ou "expressionismo abstrato", como classifica Gombrich. Segundo ele,

O emaranhado resultante de linhas satisfaz dois padrões opostos de arte no século XX: o anseio de simplicidade, espontaneidade pueril [...] e na extremidade oposta o interesse sofisticado pelos problemas de "pintura pura" [...]. (GOMBRICH, 1985, p. 479)

\section{O impossível possível}

O século XX pode ser considerado também o século do "impossível possível”. Não bastasse colocar no ar um objeto mais pesado que o ar, muitas outras coisas impossíveis tornaram-se possíveis, tornaram-se fatos - informação, no sentido morfológico da palavra - com impactos desestruturadores da visão de mundo vigente. Destaque-se aqui, como marco do "impossível possível”, a visão do planeta Terra a partir da Lua, imagem que, segundo KerCKHOVE (1997), ainda não foi totalmente processada pela humanidade. O pisar na Lua representa aqui a quebra de paradigmas do pensar humano e expressa o desenvolvimento tecnológico que vai permear todo século $\mathrm{XX}$ e adentrar o século XXI. 
Esta "desarrumação" está implícita no movimento estudantil europeu (1968), no movimento hippie e no movimento punk (por volta dos anos 70 do século passado). Os dois últimos referidos apontam para uma nova estética - de traços românticos e de traços góticos, respectivamente, se observados pelo uso das cores. E é no uso das cores que os chamados hippies deixam sua influência. Já os punks deixaram marcas através dos fanzines, publicações underground que rompem todas as regras da tipografia. Mas, ao que parece, não estabeleceram novos paradigmas tipográficos, embora tenham deixado suas marcas nas publicações atuais.
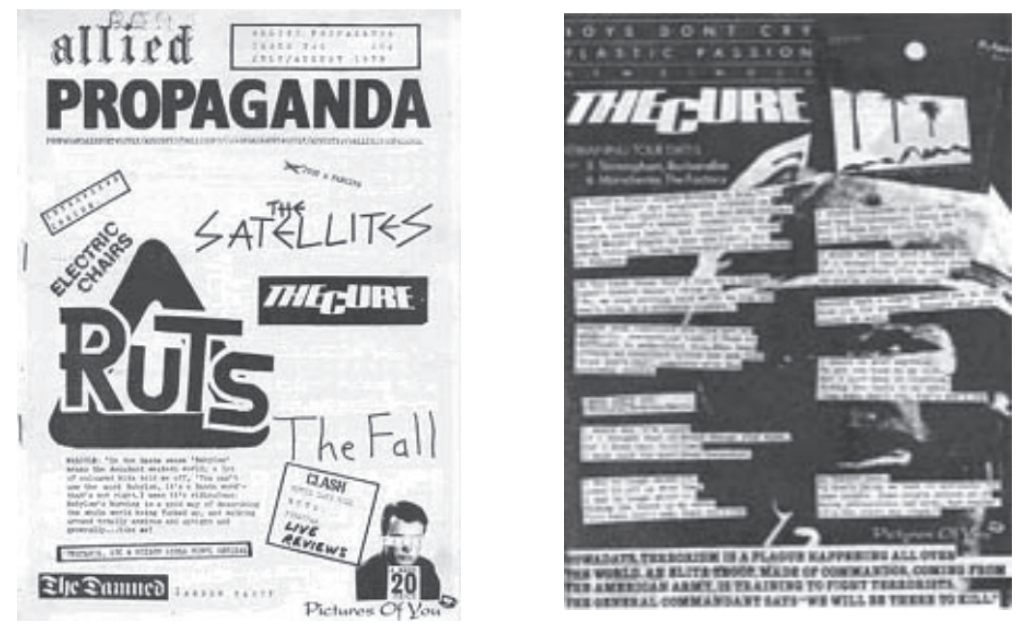

Exemplo de fanzines. , marcas da presença punk nos impressos atuais. 


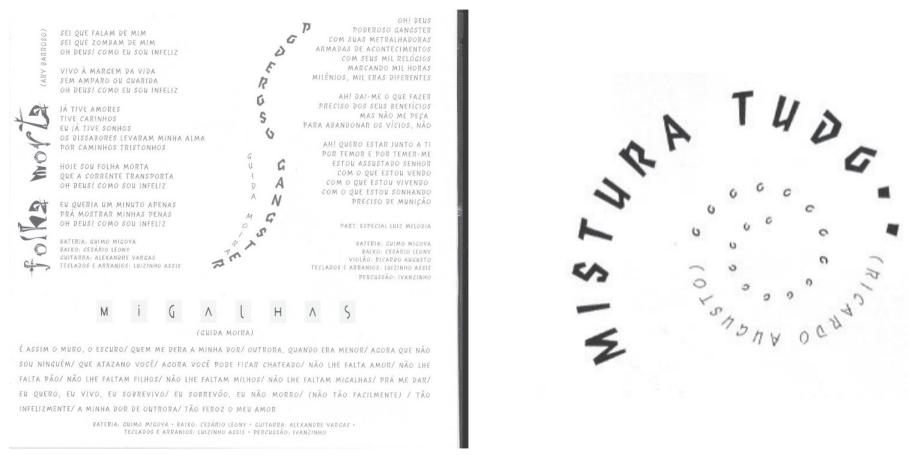

CD Guida Moira - Salvador BA - 1997 -Detalhes do encarte criado por Dania Azoubel.

É curioso observar que o chamado "punkismo" emerge a reboque da morte dos processos de composição tradicionais que, mesmo com entrada da fotocomposição, mantinham características artesanais. Isto porque, mesmo com o processamento eletrônico das letras em papel foto sensível - a fotocomposição - ainda eram necessários profissionais especialistas do cálculo tipográfico - o diagramador, e o profissional encarregado de montar as páginas, colar no diagrama (past-up) os pedaços de papel foto sensível para compor a página - o arte-finalista, entre vários outros, inclusive no ambiente gráfico-industrial.

Se possível associar a "revolta" punk com a revolução estética apontada por Gombrich no final do século XIX, poder-se-ia afirmar que os fanzines representariam, de certa forma, a insatisfação com a homogeneidade dos produtos impressos a partir de processos eletrônicos e uma tentativa de retorno à artesania.

Isto porque a nova tecnologia de produção de impressos, nos seus primórdios, ganha em velocidade e em qualidade de impressão, mas perde um pouco dos recursos gráficos, da rique- 
za estética, da variedade do design das letras, abundantes na tipografia tradicional. Esta deficiência vai ser suprida, de certa forma, pelas letras transferíveis, conhecidas como letraset, que ofereciam ao artista gráfico um sem número de fontes tipográficas, símbolos e signos usados na arte-finalização de impressos. Como na época da arte nouveau, as letras serviam mais a títulos e logomarcas do que a composição do texto.

\section{Tipografia e tecnologia}

A conversão de sinais analógicos em dígitos abre a possibilidade de representar tudo através de números. Tudo, aparentemente, pode ser numericamente representado e processado pelos computadores, inclusive a inteligência humana. Não cabe aqui discutir a veracidade ou viabilidade das possibilidades apontadas pelas tecnologias digitais. O fato é que esta tecnologia inaugura uma nova forma de leitura, a leitura eletrônica.

E a leitura eletrônica vai exigir o design de caracteres específicos para propiciar a leitura aos computadores, caracteres que, nos primórdios, aparecem nos impressos, especialmente em anúncios, cartazes, e eventualmente em títulos, como indicativo de modernidade, em que pese uma certa perda da velocidade de leitura para o leitor humano.

\section{0 련ㄷ? 8प110 टर्य4 56 Р日प11"}


Este design de letra durou pouco, não só pela perda de legibilidade. O próprio avanço tecnológico vai aproximar cada vez mais a leitura eletrônica da leitura humana. Esta aproximação deu a leitura eletrônica a (quase) flexibilidade da leitura humana, a ponto de as máquinas hoje reconhecerem, inclusive, letras manuscritas não importando o autor.

$\mathrm{O}$ avanço tecnológico expresso também no uso intensivo de computadores pessoais, na comunicação através da rede mundial de computadores - WEB - parece não ter ainda desenvolvido uma estética própria, uma "estética digital", digamos assim. Ao que tudo indica, leva-se para a tela os mesmos valores estéticos do impresso, isto quando são conhecidos pelos chamados web designers. Do ponto de vista do design de tipos, só recentemente surgem tipos adaptados à leitura humana em tela, entre eles a Verdana e a Geórgia - variações das tradicionais letras bastonadas (Futura, Arial, Helvética, entre outras) e das serifadas (Times, Garamond, Bodoni, entre outras), respectivamente, onde se observa maior peso nas hastes, possivelmente para compensar a passagem da luz.

\section{ABCDEFG HIJKLMNOPQRSTUWXYZ abcdefghijklmnopqrstuvwxyz}

Geórgia

\section{ABCDEFG HIKLMNOPQRSTUWXYZ abcdefghijklmnopqrstuvwXyz}

Verdana

136 A arte sutil da tipografia 
Apesar do esforço de desenvolver uma tipografia específica para a leitura em tela, observa-se o uso cada vez mais freqüente dos emoticons, uma ideografia que utiliza caracteres disponíveis nos teclados para criar formas que transmitem idéias e emoções. Ideografia esta instigante na medida em que remete ao bustrofédon e caminha para superar a frieza, ou objetividade do texto ao sugerir o "tom da mensagem" (Farias, 1998, P.79).

\begin{tabular}{|c|c|c|c|c|c|}
\hline$:-) \mathrm{x}$ & Arrumado para sair & H) & dormindo & $\wedge_{0}^{\wedge}$ & feliz 2 \\
\hline$(:::[]:::)$ & B and-aid & $:-)$ & feliz1 & $:-))$ & muito feliz \\
\hline :-\# & Beijo 1 & $:-\mathrm{v}$ & falando & $\%+($ & machucado \\
\hline$:-^{\star}$ & Beijo 2 & $:-\mathrm{p}$ & fazendo careta & $(*)(*)$ & seios grandes \\
\hline$:-\mathrm{x}$ & Beijo 3 & $:-\|$ & furioso & :@) & porco borito \\
\hline$:-\mathrm{O}$ & Bocejando & :-@ & gritando & $:-(($ & muito triste \\
\hline$(:-)$ & Careca & $: 1$ & pensativo & $\left(* V^{*}\right)$ & coruja \\
\hline$><{ }^{\star \star}><$ & Caranguejo & $\left\langle\left(-_{-}-\right)\right\rangle$ & mestre jedy & $: " '-($ & chorando \\
\hline$:-0$ & Chocado & :[ & muito decepcionado & 8-) & usando óculos \\
\hline$: '-($ & Chorando 1 & $\{:-)$ & novo penteado & $(-)$ & corte o cabelo \\
\hline$:,($ & Chor ando 2 & $x-($ & o usuário morreu & $:-\mathrm{D}$ & rindo muito alto \\
\hline$:-*)$ & Com gripe & $:>$ & o que? & @-,-一- & rosa \\
\hline :8) & porco & $:-t$ & rabugento & $\left({ }^{*} V^{\star}\right)$ & Coruja \\
\hline$:-\mathrm{C}$ & de que ixo caido & $=:-)$ & punk & $0:-)$ & santinho \\
\hline$:-e$ & desapontado & 8) & seu sapo & $>:-)$ & sinistro \\
\hline$:-7$ & desconfiado & $:-) \sim$ & babando & $:-($ & triste \\
\hline$:-1$ & desconfiado & $:-)-8$ & menina crescida & $3:-)$ & vaca \\
\hline
\end{tabular}




\section{Conclusão}

Se antes as máquinas absorveram as técnicas artesanais desenvolvidas pelo homem, atualmente o aparato tecnológico se impõe ao homem exigindo uma nova artesania.

As estações gráficas, os aplicativos de composição eletrônica e as novas formas de reprodução de impressos revolucionaram os processos gráficos. O impacto destas transformações guarda certa similaridade com o início da imprensa, na medida em que se verifica velocidade na duplicação e perda de qualidade visual. É notável que a estética do processo de reprodução de impressos iniciado com Gutenberg precisou de menos meio século para se estabelecer, com Aldo Manucio, apesar de não dispor dos conhecimentos científicos nem dos recursos tecnológicos atuais.

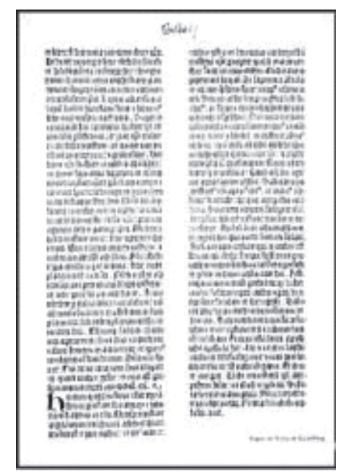

Página de Gutenberg - 1450.

138 A arte sutil da tipografia 


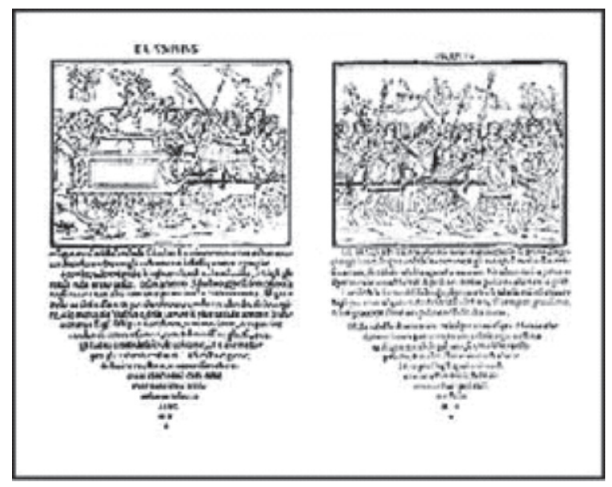

Páginas do incunábulo de Francesco Colonna, Hypnerotomachia Poliphi, publicado em 1499, por Manucio

Esta constatação aponta para questionamentos relacionados com a mecanização do processo produtivo, nos primórdios baseada na artesania, na arte enquanto conjunto de regras desenvolvido pelos artesãos, no saber ou perícia transmitido aos aprendizes nas corporações de ofício. Isto permite concluir que a mecanização não foi mais do que a sistematização de processos conhecidos e dominados. Como lembra Magalhães (1975, p. 97), o que Gutenberg fez foi muito mais a idéia de sistematização de um processo em termos da sua possibilidade industrial. A afirmação vale não só no que refere a imprensa, mas a vários outros processos do início da industrialização. Esta relação praticamente direta com os saberes e perícias artesanais talvez explique a rápida maturação dos novos processos produtivos, aqui referindo especificamente ao início da imprensa. Em contrapartida, a sociedade tecnológica se distanciou da artesania. Disponibilizou um modus faciendi também distante dos processos mecânicos que deram base à industrialização, por conseqüência, estamos diante de um modo de fazer carente de saberes e perícias que permi- 
tam explorar qualitativamente todo o conhecimento e o aparato tecnológico disponível.

Não por outro motivo se buscou aqui explorar a relação entre a arte e a tipografia, ambas instrumento de comunicação em suporte palpável por mais de 3.500 anos e que agora tem como suporte a luz emanada de uma tela, um suporte impalpável, para não usar o termo "virtual". Em suporte palpável ou não, o fato é que a escrita, através do alfabeto, ainda é o meio mais utilizado nas novas mídias mantendo viva e atual a tipografia. Mas a mudança radical na base tecnológica, nos processos produtivos, está criando uma nova roupagem para a tipografia, enquanto linguagem visivel (FARIAS, 1998).

$\mathrm{Na}$ nova roupagem, mais uma vez se observa a relação da tipografia com as artes, com o modo de fazer de cada época, arte como saber ou perícia em empregar os meios para conseguir um resultado, resultado que, ao que tudo indica, busca novos caminhos para comunicação grafada. Os emoticons representam a nova forma de escrita que explora os caracteres dos teclados de computadores, elemento básico da nova base produtiva. Curiosamente, estes emoticons, possivelmente uma nova ideografia, apresentam uma variação de sentido da leitura como ocorria ao início da escrita. A variação, pelo que se pode observar, se deve à posição dos caracteres no teclado, a nova ferramenta de construção de signos, como o foram o carvão, o metal, a pena, a liga de chumbo, antimônio e estanho inventada por Gutenberg.

Os "ícones emocionais" trazem à tona um elemento nem sempre percebido na escrita alfabética - a emoção - decorrência de uma cultura que segmenta campos de estudo. $O$ fato de a tipografia, como a arte, refletir as tendências de cada época, como

140 A arte sutil da tipografia 
visto aqui, é uma constatação instigante na medida em que a cultura européia, da qual somos herdeiros, é uma cultura letrada cuja característica mais evidente é o dualismo entre razão e emoção, esta evitada, suprimida no texto, na comunicação escrita depositária do conhecimento. Entretanto, poder-se-ia afirmar que apesar de toda contenção racionalista, a emoção sempre esteve presente na tipografia, na linguagem visível, independente do conteúdo expresso no texto.

Ao que parece, e apenas como um possível caminho para pesquisa posterior, a nova grafia que circula nas infovias - os emoticons - poderá ter impactos tão profundos para o pensamento humano quanto a imprensa e vai acrescentar à escrita um elemento específico da linguagem oral: o tom da mensagem. Neste sentido, é possível afirmar que a nova linguagem despreza objetividade tão cara ao conhecimento e com ela todos os valores desenvolvidos para a comunicação escrita, inclusive o alfabeto. Além disto, o fato de permitir a leitura, a decodificação da mensagem, independente da língua do emissor, remete ao que já ocorre em alguns países asiáticos e aponta a possível superação da "torre de babel". Ou, quem sabe, uma ponte para um novo tipo de conhecimento.

\section{Referências}

A ARTE NOS SÉCULOS. Ed. Abril, 1969.

ARAÚJO, Emanuel. A construção do livro. Rio de Janeiro: Nova Fronteira; Brasília: INL, 1986.

BURKE, Peter. Uma história social do conhecimento. Rio de Janeiro: Zahar, 2003

BURNS, Edward McNall. História da Civilização Ocidental. 3 ed. Porto Alegre: Globo, 1974. 
CASTRO, Sonia. Design e comunicação social na Bahia. Salvador: EdufBa, 2004. CHILDE, V. Gordon. Evolução cultural do homem. 3 ed. Rio de Janeiro: Zahar, 1975.

FARIAS, Priscila L. Tipografia digital - o impacto das novas tecnologias. Rio de Janeiro: 2AB, 1998.

FERLAUTO, Claudio. A. R. O tipo da gráfica, uma continuação. São Paulo: Rosari, 2002.

GOMBRICH, E. H. História da Arte. 4 ed. Rio de Janeiro: Zahar, 1985.

HOBSBAWM, Eric. Era dos extremos - o breve século XX. São Paulo: Cia das Letras, 1995.

KERCKHOVE, Derrick de. A pele da cultura. Lisboa: Relógio D’Água, 1997.

FRATICOLA, Paola L. Artigo. Disponível em http://www.varro.info (Acessado em dezembro 2004)

MAGALHÃES, Aloísio et alli. Editoração hoje. Rio de Janeiro: FGV, 1975.

MANGUEL, Alberto. Uma história da leitura. São Paulo: Cia das Letras, 1997.

MUSEU CALOUSTE GULBENKIAN. O livro objecto de arte. Lisboa: Coleção Calouste Gulbenkian, França, séc. XIX - XX 1997.

RIBEIRO, Milton. Planejamento Visual Gráfico. Brasília: Linha Graf. Ed. 1983.

ROCHA, Claudio. Projeto tipográfico - análise e produção de fontes digitais. São Paulo: Rosari, 2002.

WELLS, H.G. História Universal. São Paulo: Cia. Editora Nacional, 1972.

WIENER, Norbert. Cibernética e sociedade. 4 ed. São Paulo: Cultrix, 1973.

\section{PORTAIS}

www.imultimedia.pt

www.juanval.net/fundamentos_tipometría.htm

www.proel.org

www.unostiposduros.com/laperla

www.varro.info

142 A arte sutil da tipografia 


\section{Cópia de livros}

Nas universidades brasileiras

Flávia G. M. G. Rosa

Susane S. Barros

Nanci Oddone

\section{Introdução}

O surgimento das universidades na Idade Média foi fator decisivo para o aparecimento de um público leitor. Em torno desse novo ponto de passagem na circulação do saber (LATOUR, 1999), desenvolveu-se um comércio de cópias manuscritas. A autoria destas obras nem sempre era conhecida, pois alguns autores sofriam punições ao manifestar livremente seu pensamento. Ao longo da história, novas tecnologias intelectuais (LÉVY, 1993) sempre contribuíram para ampliar o acesso à informação. No século XV, um marco importante foi a tipografia de Gutemberg. Nesse período, o direito autoral não era tratado da forma como é visto hoje, 
mas o advento da imprensa trouxe novos papéis para os atores da cadeia editorial.

A possibilidade de aumento no número de exemplares produzidos, a partir dos processos de impressão, estabeleceu relações diferentes entre autor, editor, livreiro e o próprio leitor. Mas somente no século XVIII, de forma pioneira, a Inglaterra estabelece uma lei que concede ao autor o direito exclusivo de imprimir sua obra. O grande marco, no entanto, foi a Convenção de Berna em 1883, que através da assinatura de um acordo entre vários países, passou a proteger o direito do autor para obras literárias e artísticas.

Segundo Guilherme Carboni (2004), hoje o direito do autor passa de mecanismo de estímulo à criação intelectual a poderosa ferramenta de apropriação da informação enquanto mercadoria, reduzindo a esfera de liberdade de expressão e construindo obstáculos para o acesso ao conhecimento. Desse modo, a crise do direito do autor torna conflitante o interesse individual do autor pela autoria de sua criação e o interesse coletivo pelo desenvolvimento cultural, econômico e tecnológico.

A base do tema aqui tratado são os atores que compõem a rede de associações que gira em torno do objeto livro, enfocando as variáveis que determinam o fenômeno das cópias de livros no meio acadêmico. Busca-se também identificar as propostas de ação que vêm sendo sugeridas por diversas organizações para não descumprir a lei do direito do autor. $\mathrm{O}$ direito de acesso à informação e, por outro lado, o direito à propriedade intelectual são algumas questões fundamentais que estão em foco este trabalho. 


\section{Direito autoral no mundo}

As universidades surgem na Europa no final do século XII, início do século XIII, contribuindo para o aparecimento de um público leitor constituído por professores e estudantes, à procura de textos, obras de referência, comentários de textos e manuscritos. Para atender a essas necessidades, copistas profissionais se multiplicavam em volta das universidades, formando verdadeiras corporações. No século XV, a revolução, desencadeada pela imprensa em relação ao registro e à disseminação da informação colaborou para aumentar rapidamente a disponibilidade de textos impressos satisfazendo à demanda das universidades. Como se sabe, ao longo da história, essas universidades foram responsáveis por grande parte do conhecimento produzido no mundo.

Nos séculos XVI, XVII e XVIII a atividade editorial estava relacionada, sobretudo, ao comércio do livro, centrada na figura do "livreiro-editor". De acordo com Chartier além de vender os livros que editava, os livreiros vendiam os livros que obtinham através de troca com outros livreiros, que por sua vez desempenhavam a mesma função. Esses atores tinham, portanto, uma posição privilegiada e dominavam grande parte do mercado livreiro, pois detinham os direitos sobre a obra. Chartier afirmou "a atividade de livraria comanda[va] [...] a atividade de edição, seus mecanismos e seus limites” (1998, p. 54).

Na Inglaterra, no século XVI, por decisão da monarquia, o controle do que se publicava foi delegado à comunidade, à corporação dos livreiros-gráficos londrinos. Desse modo, ao obter um manuscrito, o livreiro ou gráfico o registrava e assegurava, a partir daí, o direito "[...] perpétuo e imprescritível 
[...] de editá-lo e reeditá-lo indefinidamente" (CHARTIER, 1998, p. 55). Este fato levou muitos escritores a assumirem a publicação das próprias obras. Somente a partir de 1710 é que a monarquia inglesa limitou o prazo do copyright, protegendo os autores dos abusos praticados pelos empresários gráficos, concedendo aos autores o exclusivo direito de imprimir suas obras, após o prévio registro das mesmas. Desta forma, a Inglaterra foi o primeiro país do Ocidente a estabelecer uma lei para o direito autoral.

A historiadora Elizabeth Eisenstein defende a idéia de que somente após o aprimoramento da imprensa e dos tipos móveis, por Gutenberg, foi possível diferenciar os papéis do autor, do escriba, do tradutor, do comentarista, do compilador e definir, de fato, o conceito de autoria. Sobre o direito autoral, Eisenstein afirma o seguinte:

A competição pelo direito de publicar um dado texto gerou também controvérsias a respeito de novos tópicos, como o monopólio e a pirataria. A imprensa trouxe a necessidade de definir legalmente o que pertencia ao domínio público. Uma espécie de 'terra de ninguém' literária tornou-se com o tempo objeto de um 'loteamento' e um individualismo começou a caracterizar a atitude dos escritores para com suas obras. Os termos plágio e direito de reprodução [...] não existiam para o menestrel. Somente depois do advento da imprensa é que passaram a ter significação para o autor. (EISENSTEIN, 1998, p. 101)

$\mathrm{Na}$ França a interferência do Estado era muito mais ampla, sendo os privilégios e permissões de livrarias concedidos pela monarquia. A partir de 1777 foi que os autores, e não só os livreiros, passaram a ter o privilégio de publicar e muitos tentaram transformar-se em editores. Finalmente, foi com as dis- 
cussões das assembléias revolucionárias que o Estado francês interveio fortemente na legislação para proteger o autor e o público em seus direitos de, respectivamente, ser remunerado por seu trabalho e ter acesso às obras originais (CHARTIER, 1998). Após a revolução de 1789 definiu-se um prazo para a propriedade literária, ou seja, um prazo para que a obra se tornasse pública, iniciativa que vigora até os dias atuais.

Ao longo do tempo, vários acordos e congressos internacionais foram realizados e tinham como foco a proteção dos direitos dos autores. A Bélgica, em 1858, foi o primeiro país a realizar uma conferência internacional sobre o tema. A terceira conferência diplomática sobre direitos autorais - que resultou num importante documento, o mais antigo tratado internacional em defesa e proteção dos direitos patrimoniais e morais do autor foi realizada em Berna, em setembro de 1886. O documento sofreu várias revisões, sendo a última em 28 de setembro de 1979, a qual tem servido como base para as legislações sobre direitos autorais de vários países, inclusive o Brasil.

Outra recomendação desses congressos, adotada com o apoio da maioria dos Estados, foi o princípio de que "[...] a propriedade das obras literárias e artísticas em favor de seus autores deve inscrever-se na legislação de todos os povos civilizados" (LINS, 1974, p. 78). Assim, “[...] o direito do autor deve ser concedido aos autores dos países membros sem qualquer exigência referente a formalidades" (HAMMES, 1984, p. 32). Em 1948, após a Segunda Guerra Mundial, a Declaração Universal dos Direitos Humanos, em seu artigo 27, item 2, estabelecia que "todo homem tem direito à proteção de seus interesses morais e materiais decorrentes de qualquer produção científica, literária ou artística da qual seja autor” (ORGANIZAÇÃO, 1948). 
Ocorreu em Estocolmo, em 14 de julho de 1967, uma importante conferência internacional onde foi instituída a World Intellectual Property Organization (WIPO - Organização Mundial de Propriedade Intelectual) que passou a vigorar em 26 de abril de 1970. Sendo uma instituição especializada do Sistema das Nações Unidas, o objetivo da WIPO é "promover melhor compreensão e colaboração entre os Estados [...] [e] encorajar a atividade criativa promovendo a proteção da propriedade intelectual no mundo" (HAMMES, 1984, p. 147).

\section{Direito autoral no Brasil}

No Brasil, antes da Convenção de Berna, o direito do autor estava assegurado pela Lei Imperial de 1827, que protegia o trabalho intelectual por um período de dez anos, mas não se baseava em nenhuma documentação internacional. Somente em 1898, os efeitos da Convenção de Berna vieram a ser sentidos no Brasil através da Lei 496, que estendeu o período de proteção do direito autoral por dez anos após a morte do autor se este tivesse deixado herdeiros. Com a entrada em vigor do Código Civil de 1912, cujos artigos 649 a 673 regulamentavam a matéria, houve uma complementação da lei 496, quando foi reconhecido o direito de autor às obras publicadas em países estrangeiros, qualquer que fosse a nacionalidade dos autores.

Em 14 de dezembro de 1973, após vários anos de estudos e discussões, o Congresso Nacional promulgou a Lei $n^{\circ} 5$ 988, que definiu o direito autoral e estabeleceu as penalidades no caso do descumprimento da mesma. 
A Constituição Federal, promulgada em 5 de outubro de 1988, também dispõe de proteção ao direito do autor. Em seu capítulo 1 , artigo $5^{\circ}$, a Constituição dá a seguinte redação aos direitos e deveres individuais e coletivos:

XXVII - aos autores pertence o direito exclusivo de utilização, publicação ou reprodução de suas obras, transmissível aos herdeiros pelo tempo que a lei fixar;

XXVII I - são assegurados, nos termos da lei:

a) a proteção às participações individuais em obras coletivas e à reprodução da imagem e voz humanas, inclusive nas atividades desportivas;

b) o direito de fiscalização do aproveitamento econômico das obras que criarem ou de que participarem aos criadores, aos intérpretes e às respectivas representações sindicais e associativas (BRASIL, 1988).

A Lei n ${ }^{o} 9.610$ foi promulgada em 19 de fevereiro de 1998 para regulamentar os itens dispostos na Constituição, estabelecendo as formas de controle e estipulando o tempo durante o qual este direito pode ser exercido. Nesta Lei, o inciso 1 do artigo $5^{\circ}$, conceitua publicação como "o oferecimento de obra literária, artística ou científica ao conhecimento público, com o consentimento do autor, ou de qualquer outro titular do direito do autor, por qualquer forma ou processo". No capítulo 4, o artigo 46, sobre as delimitações dos direitos autorais, dispõe, em seu inciso 2, que “a reprodução em um só exemplar de pequenos trechos, para uso privado do copista, desde 
que feito por este, sem intuito de lucro não constitui ofensa aos direitos autorais". A subjetividade do legislador no que diz respeito a "pequenos trechos" tem gerado discussões polêmicas, sobretudo no meio acadêmico.

Por outro lado, em 02 de agosto de 2003 entrou em vigor a Lei $n^{\circ} 10.695$, que alterou os dispositivos do Código Penal e do Código de Processo Penal no que se refere à tipificação do crime de violação do direito autoral e às medidas processuais cabíveis. Carboni comenta o seguinte no que tange ao artigo 46:

[...] a Lei 10.695/03 resolve definitivamente a polêmica questão a cerca da cópia única para uso privado do copista, sem intuito de lucro, ao inserir o parágrafo $4^{\circ}$ no artigo 184, que exclui tal prática, de forma expressa, da incidência das penas previstas nos parágrafos precedentes. Portanto, copiar obra integral, em um só exemplar, para uso exclusivamente privado, sem intuito de lucro, não é tipificado como crime.

Essa, porém, não era a regra do nosso ordenamento jurídico até a entrada em vigor da Lei 10695 razão pela qual tal alteração é muito bem vinda. De fato, o artigo 46, inciso II, da Lei de Direitos Autorais, diz que não constitui ofensa aos direitos do autor " a reprodução em um só exemplar, de pequenos trechos, para uso privado do copista, desde que feita por este, sem intuito de lucro". Portanto, a limitação ao direito de autor contida no referido artigo legal seria aplicada apenas à reprodução de pequenos trechos e não de obra integral. É por essa razão que a cópia integral de uma obra qualquer, como um livro, por exemplo, até a entrada em vigor da Lei 10 695, era tipificada como crime de violação do direito do autor. 
No entanto, apesar de a Lei no 10.695/03 ter expressamente excluído da tipificação penal a reprodução privada da obra para uso particular do copista, em um único exemplar, sem intuito de lucro, o fato é que continua em vigor a regra do artigo 46, inciso II, da lei de Direitos Autorais. Portanto, o titular dos direitos autorais ainda pode ingressar com uma ação na esfera civil, visando a apreensão das obras reproduzidas ou a suspensão da prática, além do pagamento de uma indenização pela reprodução integral não autorizada. Por essa razão, já existem diversos estudos em andamento visando alterar a redação do artigo 46, inciso II, da Lei de Direitos Autorais, de forma a permitir a cópia integral nos termos estabelecidos pela Lei no 10 695/03.

Em 2005, tramitou no Congresso Nacional o Projeto de Lei $n^{\circ}$ 5.046, que autorizava a reprodução de livros, desde que sem fins comerciais, para uso exclusivo de estudantes universitários. Este projeto foi submetido à Câmara pelo deputado Antonio Carlos Mendes Thame em abril do mesmo ano. Na Comissão de Educação e Cultura a proposta não recebeu nenhuma emenda no prazo regimental e tramitou em caráter conclusivo, isto é, não seria necessário que o Plenário abrisse uma votação para que a Câmara o considerasse aprovado, bastando apenas que as comissões designadas para analisá-lo o aprovassem. O relator dessa proposta foi o deputado Chico Alencar que, no dia 1 de setembro, emitiu parecer favorável ao Projeto de Lei, destacando "[...] o enorme alcance educacional e cultural, que é também um alcance social, de uma proposta [...] que visa permitir ao estudante universitário, exclusivamente e sem fins comerciais, o acesso a qualquer obra pela via de reprodução reprográfica, desde que limitada a um só exemplar”. O relator ainda complementou: "a proposição do nobre Deputado Antonio Carlos Mendes Thame deve, portanto, ser vista como uma via alternativa válida, justa e de grande mérito pelo aprimoramento intelectual que pode propiciar aos universitá- 
rios brasileiros." Em outubro de 2005, o deputado Jonival Lucas Júnior apresentou em um requerimento para retirada do projeto antes de ir ao Plenário para ser votado.

O Ministério da Justiça (MJ), em outubro do ano passado, criou o Conselho Nacional de Combate à Pirataria e Delitos contra a Propriedade Intelectual. Este órgão dedica-se a proposição do Plano Nacional de Ações contra a Pirataria cujo objetivo é combater a pirataria, a sonegação fiscal que é por ela gerada e os crimes contra a propriedade intelectual. Este plano abrange não apenas a indústria editorial, mas também as indústrias de confecções, calçados e especialmente a fonográfica, possuindo algumas ações direcionadas para coibir a reprodução de livros, embora não haja propriamente pirataria e sim reprodução ilegal.

Fundada em 1992, a Associação Brasileira de Direitos Reprográficos (ABDR) atua como entidade representativa das editoras no combate à cópia de livros. Em 16 de março de 2004 a ABDR uniu-se à Associação Brasileira para a Proteção dos Direitos Editoriais e Autorais (ABPDEA), fundada em 1999, com o objetivo de

conscientização da população sobre a necessidade de se respeitar o direito autoral, na esteira da Lei $n^{\circ} 9.610 / 98$, que o regulamenta no Brasil, esclarecendo, educando, proporcionando encontros e discussões sobre a preservação desses direitos, atuando como entidade 'fiscalizadora e repressora da reprodução ilegal das obras de seus associados' (grifo nosso) (ASSOCIAÇÃO...).

A ABDR vem agindo de forma repressora através de "ações policiais [que] são planejadas a partir de denúncias anônimas feitas ao site da associação", tendo como foco as instituições de 
ensino superior (IES), defendendo desse modo as 160 editoras a ela filiadas, que correspondem a $90 \%$ das principais editoras do País.

\section{A construção do saber e a universidade}

As universidades são responsáveis por grande parte das pesquisas científicas desenvolvidas no mundo, produzindo, sistematizando e difundindo informações e gerando conhecimento. No entanto, para que a produção científica das IES seja disseminada é necessário, de um lado, o intercâmbio de informações e idéias entre os cientistas e, de outro, uma política institucional específica que apóie e valorize a produção intelectual.

No entanto, a cultura do sistema educacional brasileiro, destacando o universitário, não favorece a valorização do direito autoral. Além disso, até mesmo os empresários do livro, muitas vezes não tratam a questão com a responsabilidade devida. Segundo Osman Lins, "com o objetivo de amenizar seus riscos [...] nossos editores, quase todos, quando se decidem a lançar um livro brasileiro, [agem] de maneira muito discutível no que se refere aos direitos autorais" (1974, p. 76).

A falta de consciência sobre o direito autoral está aliada a fatores como: a popularização das máquinas reprográficas, ao surgimento de novos suportes de informação, a condição sócio-econômica dos estudantes, e a situação dos acervos das bibliotecas universitárias, sobretudo das IES públicas.

A instalação de máquinas reprográficas vem se multiplicando a cada dia nas universidades, sendo ainda respaldada pelos crité- 
rios de avaliação para reconhecimento de cursos de graduação estabelecidos pelo Ministério da Educação (MEC). No que concerne à infra-estrutura, no item biblioteca, no indicador serviços, para efeito de avaliação considera que ela deve fornecer, dentre outros serviços "acesso a serviço de cópia de documentos internamente na instituição (ainda que não no espaço físico da biblioteca)" (BRASIL, 2002).

Atualmente, a cópia parece ser um instrumento indispensável ao ensino de uma disciplina porque, ao contrário do que ocorria há trinta ou quarenta anos, não é mais possível ao professor se decidir - ou se limitar a - um único livro-texto. E não há livros-texto para as diversas disciplinas porque o conhecimento se fragmentou, os autores se multiplicaram e as edições são muito mais numerosas. Dessa forma, um professor não encontra e, por outro lado, não se satisfaz mais em definir um único autor como a principal autoridade naquele assunto: não existem mais autores que sejam autoridades absolutas em seus próprios assuntos. Por isso, não existem mais fontes e obras consideradas definitivas sobre cada tema: "a escrita de livros está crescendo exponencialmente. Se nossa paixão por escrever não for controlada, no futuro próximo haverá mais pessoas escrevendo livros que lendo" (ZAID, 2004, p. 13).

Se, para compreender bem determinado assunto - seja de forma panorâmica ou pormenorizada - um aluno precisa ler três, quatro, cinco ou às vezes mais autores e obras, como obrigar o aluno a comprá-las se o próprio professor admite que cada obra, isoladamente, não é suficiente? Se a cada aluno é dito que o melhor ou importante daquele autor é apenas um determinado capítulo de um livro, porque o aluno iria comprá-lo, considerando sua condição sócio-econômica? 
Tudo indica que o próximo estágio desse embate será o "livro didático universitário", composto por recortes que os professores efetuariam na lista de referências básicas de cada disciplina. Assim, um livro que servisse aos alunos da USP poderia não servir aos da UFBA - e, dentro da mesma universidade, poderia não servir a dois professores da mesma disciplina. Ou, ao contrário, poderíamos chegar à completa uniformidade de pensamento: todos os brasileiros lendo pelas mesmas cartilhas e pagando royalties sempre aos mesmos "autores". Em qualquer caso, o conhecimento, em cada área e em cada disciplina, ficaria restrito ao "editorialmente autorizado", desestimulando e até mesmo bloqueando a diversidade cultural e a autonomia de pensamento. Além disso, as próprias editoras iriam formar grupos que entrariam em árduas disputas financeiras para produzir esses "materiais didáticos", tal como já se vê hoje em torno do livro didático do ensino fundamental e do ensino médio.

Outro fator que consideramos determinante para o fenômeno das cópias é a condição sócio-econômica dos estudantes. Isso parece ser visivelmente, conseqüência do baixo crescimento econômico do País, que se reflete no poder aquisitivo da maioria da população, contribuindo assim, para que o livro seja visto como artigo de luxo.

Nesse sentido as bibliotecas têm a função de prover o acesso à informação. Para tanto, é necessário que elas possuam acervos atualizados e com a quantidade de exemplares compatível com a quantidade de alunos, bem como tecnologias informacionais adequadas às novas formas de acesso à informação. Quanto ao acervo das bibliotecas universitárias, o MEC estabelece critérios de avaliação para reconhecimento de cursos de graduação 
e no que se refere ao item biblioteca, no indicador acervo considera no que se refere a livros:

Muito fraco - quando não atendem aos programas das disciplinas, não há quantidade suficiente (na proporção de um exemplar para mais de 20 alunos matriculados no curso, para quaisquer dois títulos selecionados pelo docente da disciplina) e não são atualizados.

Regular - quando atendem parcialmente aos programas das disciplinas, a quantidade é razoável (na proporção de um exemplar para mais de 10 até 20 alunos matriculados no curso, para quaisquer dois títulos selecionados pelo docente da disciplina) e são parcialmente atualizados.

Muito bom - quando atendem aos programas das disciplinas, há quantidade suficiente (na proporção de um exemplar para até 10 alunos matriculados no curso, para quaisquer dois títulos selecionados pelo doente da disciplina) e são atualizados. (BRASIL, 2002)

Esta categorização está muito aquém da necessidade real dos estudantes, sobretudo no que se refere à bibliografia básica. Classificar como muito bom a proporção de um exemplar para até 10 alunos - quando, de acordo com Earp \& Kornis (2005), o padrão internacional é de "cerca de um exemplar para cada cinco usuários" - é mais um estímulo para conduzi-los à prática da cópia de livros.

O MEC, em parceria com o Ministério de Ciência e Tecnologia (MCT), anunciou, em 2004, a criação do Portal de Livros, com o intuito de possibilitar acesso aos textos completos indicados pelos professores e de acordo com as bibliografias básicas das disciplinas. Tudo indica que essa iniciativa tenha como objetivo minimizar as dificuldades econômicas dos estudantes univer- 
sitários. Segundo Kehrle "[...] além da leitura e da pesquisa, professores, pesquisadores e alunos poderão imprimir, parcialmente, as informações contidas na obra, sem descumprimento da Lei de direitos autorais. [...]" (2004). A intenção para a elaboração do portal com esse objetivo era fazer contato com os editores das publicações para uma negociação. No entanto, esta iniciativa até o momento não se concretizou. Outra questão, diz respeito à capacidade instalada de computadores no âmbito das IES, o que dificulta o acesso às obras digitalizadas. A instalação física dos institutos de pesquisa e unidades universitárias onde todos estes recursos eletrônicos de informação terão que ser consultados, lidos ou manipulados não tem sido ampliada e aparelhada com suficiente presteza para atender à crescente demanda por computadores ligados à Internet, sugerindo um futuro colapso de todo o sistema.

No entanto, sobretudo no âmbito das IES, esses avanços tecnológicos, possibilitam o aparecimento de outros suportes e de outros meios de difusão da informação, e ampliam a polêmica em torno do direito autoral uma vez que acarretam "[...] a diversidade e a ampliação do acesso público às obras intelectuais", embora, para muitos pesquisadores, seja "de extrema importância que seu trabalho seja utilizado por outros, desde que sejam feitas as referências [...]" ( PEREIRA, 2004).

\section{Uma rede de associações}

Remetendo a Latour (1997, p. 247), e levantando os possíveis atores envolvidos nesse processo - original, livro, autor, lei, cópia, editora, livraria, professor, leitores e biblioteca - e o fluxo de como esses atores se associam no processo, designa- 
do de rede de associações, eles têm o livro como um "ponto de passagem obrigatório". É em torno dele que se reúnem autores, leitores, bibliotecas, editoras, livreiros etc, sendo ele a razão de existir dos atores. Esta rede não é algo estático, pois ela está sempre em movimento e depende da força de cada ator ao longo do tempo. A força está relacionada ao poder e ao saber e, portanto a rede se movimentará na direção onde o poder estiver no momento. Cabe a organizações da sociedade civil como associações de bibliotecários, de professores e estudantes, mobilizar a população com o objetivo de fazer com que essa rede passe a tender em prol da comunidade atendendo assim aos interesses dela.

Essa rede de associações tem como ponto de partida o autor, que transforma suas idéias em um original. O original é encaminhado à editora que o publica na forma de livro. Este por sua vez será disponibilizado para os leitores através das livrarias para compra e através das bibliotecas para consulta ou empréstimo. O professor passa a participar dessa rede no momento em que ele indica para o leitor (o estudante) a bibliografia de uma disciplina. O leitor se depara com algumas opções, quais sejam elas: adquirir os livros indicados na livraria, retirá-los na biblioteca da instituição, solicitar empréstimo de alguém, ou ainda tirar cópias reprográficas. Como foi abordado anteriormente, dentre outros fatores, o econômico impede que essa aquisição ocorra na prática.

Dentre os elementos que fazem parte dessa rede de associações, a biblioteca é, no contexto universitário, um dos mais importantes, pois atua muitas vezes como fornecedora do material a ser copiado. As ações ligadas à educação, à cultura, $\mathrm{e}$ as bibliotecas têm sido historicamente preteridas. Na realidade, a política cultural brasileira, desde a chegada da Família Real, priorizou a elite, representada por pequenos grupos, em de- 
trimento da maior parcela da população. $\mathrm{O}$ acesso aos bens culturais não tem sido a motivação da política cultural aplicada no País até o momento.

Outro fator que explica a pouca atenção dispensada à biblioteca, este importante equipamento cultural, é o estágio de desenvolvimento econômico em que o Brasil se encontra. A desigualdade social, sobretudo nas regiões Norte e Nordeste do País, é acentuada e grande parcela da população não tem acesso a recursos básicos como água, alimentação, moradia, e talvez por esse motivo a educação e a biblioteca não parecem ser prioridade e não fazem parte dos planos de ação dos governos.

As bibliotecas das escolas e das universidades cumprem com muita dificuldade o papel de conduzir o indivíduo a buscar e utilizar as informações que servirão de base ao seu aprendizado e conseqüente construção do conhecimento. A escassez de recursos não tem permitido às bibliotecas universitárias atender às necessidades mínimas de suas comunidades no que diz respeito à bibliografia básica dos cursos, mesmo na proporção de um exemplar para consulta. A solução é suprir tais necessidades, sob a forma de cópias, em geral de capítulos de livros, disponibilizados, muitas vezes, na denominada "pasta do professor", ou, copiar o exemplar de consulta da biblioteca, o que causa uma rápida deterioração no exemplar. A situação ideal seria que o estudante pudesse adquirir seu próprio exemplar do livro, na livraria, o que ocorre com pouca freqüência.

As editoras, sobretudo as universitárias, como um dos atores da rede de associações, têm um papel importante na divulgação da pesquisa das universidades através de publicações científicas, sendo esta a linha editorial da grande maioria dessas editoras. A partir dos anos 80 elas ampliaram a sua participação 
do mercado editorial brasileiro, se preocupando com a difusão do conhecimento produzido nas IES, otimizando a produção acadêmica e científica, bem como, definindo critérios de seleção dos originais a serem publicados, respaldadas por Conselhos Editoriais. Porém, a atividade editorial nem sempre está inserida na política da Instituição, bem como, persistem dúvidas com relação ao caráter empresarial da editora universitária do ponto de vista da gestão e dos seus profissionais, não havendo o entendimento devido quanto ao lugar estratégico que deve ser ocupado por ela na Instituição (ROSA, 2005).

Essas editoras, no entanto, poderiam propor como alternativa, por exemplo, a produção de coletâneas que contemplem a diversidade de pensamentos. Além da produção de livros de menor custo, ou mesmo com parte desses custos subsidiados pelo próprio governo atendendo aos programas das disciplinas oferecidas pelos diversos cursos das IES.

\section{Ações propostas}

Em busca de alternativas para solucionar a questão das cópias de livros em universidades, varias ações têm sido sugeridas. A Pontifícia Universidade Católica de São Paulo (PUC-SP), propõe um sistema de intranet em que todas as obras ou trechos exigidos pelos cursos da instituição estejam disponíveis para impressão nos terminais da própria universidade. A Anhanguera Educacional que mantém 10 faculdades no interior de São Paulo criou o Programa Livro-texto. Através da parceria com quatro editoras, fazem tiragens personalizadas para as disciplinas da instituição. Com esse programa já foram publicados quatro títulos com uma tiragem de 32 mil exemplares. 
Na Universidade de São Paulo (USP) foi aprovada uma norma sobre o uso de cópias, em que fica entendido como "pequenos trechos" como colocado pela Lei ${ }^{\circ} 9.610$, capítulos de livros ou de trabalhos científicos em revistas especializadas. A Universidade Luterana do Brasil (ULBRA) criou um projeto intitulado "Cadernos Universitários", cujo objetivo é estimular a produção de material didático pelo corpo docente e conseqüentemente diminuir o uso das cópias. Em 2004 foram impressos 19.384 exemplares, sendo que 85\% deles têm um custo de $\mathrm{R} \$ 0,08$ por página incluindo a capa. Já foram publicados 302 cadernos para serem utilizados em sala de aula nos diversos cursos da instituição.

Algumas editoras comerciais, como a Forense e a Saraiva, possuem um catálogo online de obras. $\mathrm{O}$ interessado pode baixar o texto ou parte dele, de acordo com o que desejar, pagando por meio de cotas que variam entre $\mathrm{R} \$ 20,00$ e $\mathrm{R} \$ 1.000,00$ e que podem ser quitadas através de boletos bancários ou de cartões de crédito.

A Associação Brasileira de Editoras Universitárias (ABEU), em reunião anual realizada em Canela/RS, no final de agosto decidiu pelo encaminhamento da Carta de Canela, destacando importantes pontos como: implantação de uma política institucional de apoio à produção do livro universitário, inserção de percentual de 0,5 no orçamento global da instituição para a formação de um fundo que possibilite às bibliotecas universitárias adquirirem obras produzidas pelas editoras universitárias, além de estabelecer política interna inibidora de reprodução de cópias.

A própria ABDR lançou uma campanha em julho desse ano, que acabou sendo adiada, para ampliar o acervo das bibliotecas universitárias através de vendas em condições especiais, ne- 
cessitando, no entanto da adesão das editoras. Houve de imediato uma reação por parte da Associação Estadual de Livrarias do Rio de Janeiro (AEL-RJ), pois as condições especiais oferecidas às universidades retirariam "as vendas a bibliotecas da ossada dos livreiros, os quais já não participam das polpudas vendas do Programa Nacional do Livro Didático (PNLD) [...], [o que] significa estrangular ainda mais o principal canal de distribuição do livro". Mesmo sob protestos, a campanha foi implantada em outubro oferecendo $45 \%$ de desconto para as bibliotecas sobre o preço de capa, frete pago pelas editoras e prazo de até 180 dias para o pagamento dependendo da quantidade adquirida.

Os estudantes, de nove diretórios acadêmicos do Rio de Janeiro e São Paulo lançaram no final de fevereiro um movimento denominado "Copiar livro é direito" e preparam amplo material de divulgação em manifesto a favor da cópia. $\mathrm{O}$ principal argumento dos estudantes é o acesso à informação.

Como se observa, as alternativas que começam a surgir como solução para a questão das cópias de livros nas universidades, ainda não alcançaram alguns de seus pontos essenciais. Tais propostas permanecem como soluções institucionais isoladas e muitas vezes conflitantes.

\section{Conclusão}

O tema da cópia de livros nas universidades está sob controvérsia, na expectativa de soluções que atendam a todos os atores envolvidos. Há contradições flagrantes na legislação e questões que, no momento atual, são intransponíveis, como os fatores culturais e socioeconômicos. Por outro lado, alguns dos 
atores em cena têm omitido seu posicionamento em relação ao problema, agravando a polêmica.

Considerando a complexidade do fenômeno e a importância do seu esclarecimento para que se alcance um maior equilíbrio social, acredita-se que é necessário e oportuno dar continuidade a esta pesquisa. Para tanto se pensa em adotar uma estratégia metodológica voltada para a aplicação de um questionário que identifique e sistematize as diferentes variáveis em jogo. Espera-se, assim, contribuir de modo consistente para solucionar o problema cumprindo a legislação sem prejudicar o ensino ou onerar o custo da formação profissional para os estudantes.

\section{Referências}

ASSOCIAÇÃO BRASILEIRA DE DIREITOS REPROGRÁFICOS. Website. Disponível em: http://www.abdr.org.br/. Acesso em: 08 mar. 2007.

BRASIL. Constituição da República Federativa do Brasil, de 5 de outubro de 1988. Disponível em: https://www.planalto.gov.br/ccivil_03/Constituicao/ Constitui\%C3\%A7ao.htm. Acesso em: 10 fev. 2005.

BRASIL. Lei 9.610, de 19 de fevereiro de 1998. Altera, atualiza e consolida a legislação sobre direitos autorais. Disponível em: http://www.mct.gov.br/legis/ leis/9610_98.htm. Acesso em: 24 abr. 2004.

BRASIL. Lei 10.695, de $1^{\circ}$ de julho de 2003. Altera e acresce parágrafo ao art. 184 e dá nova redação ao art. 186 do Decreto-Lei 2.848, de 7 de dezembro de1940.Disponívelem:http://www.mj.gov.br/combatepirataria/servicos/legislacao/ 2003lei10695.pdf. Acesso em: 20 jun. 2005.

BRASIL. Lei 10.753, de 30 de outubro de 2003. Institui a política nacional do livro. Disponível em: https://www.planalto.gov.br/ccivil_03/LEIS/2003/ L10.753.htm Acesso em: 25 abr. 2004.

BRASIL. Ministério da Educação. Secretaria de Educação Superior. Disponível em: http://portal.mec.gov.br/sesu. Acesso em: 15 jul. 2005. 
BRASIL. Ministério da Justiça. Conselho Nacional de Combate à Pirataria e Delitos contra a Propriedade Intelectual. Disponível em: http://www.mj.gov.br/ combatepirataria. Acesso em: 20 ago. 2005.

BRASIL. Projeto de Lei 5.046, de 12 de abril de 2005. Altera a Lei 9.610. Disponível em: http: //www2.camara.gov.br/proposicoes. Acessado em: 11 jun. 2005.

CARBONI, Guilherme. Os desafios do direito autoral em tempos de Internet. Revista do Terceiro Setor, Rio de Janeiro, 12 nov. 2004. Seção Ponto de Vista. Disponível em > http://arruda.rits.org.br/notitia1/servlet/newstor.notitia.apresentação. Servelet.Desecao codigoDaSecao $=11 \&$ dataDoJornal $=11002932228000$. Acesso: 19 jul. 2005.

CARBONI, Guilherme. A lei no 10.695/03 e seu impacto no direito autoral brasileiro. Prolegis-136. Disponível em: http://psj.com.br/artigos/artigos100/ PROLEGIS-136.htm. Acesso em: 07 jul. 2005.

CARTA de Canela. São Paulo: Associação Brasileira das Editoras Universitárias, 2005. Disponível em: http://www.abeu.org.br/releases/carta_de_canela.doc. Acesso em: 26 set. 2005.

CHARTIER, Roger. As aventuras do livro: do leitor ao navegador. São Paulo: UNESP, 1998.

EARP, Fábio S.; KORNIS, George. A economia da cadeia produtiva do livro. Rio de Janeiro: BNDES, 2005. Disponível em: http://www.bndes.gov.br/conhecimento/ebook/ebook.pdf. Acesso em: 21 set. 2005.

EISENSTEIN, Elizabeth L. A revolução da cultura impressa: os primórdios da Europa moderna. São Paulo: Ática, 1998.

ROSA, Flávia G. M. Garcia. A produção editorial e as editoras universitárias. In: RUBIM,Linda (org.). Organização e produção da cultura. Salvador: EDUFBA, 2005. p. 169-183.

HAMMES, Bruno J. Curso de direito autoral. Porto Alegre: UFRGS, 1984.

KEHRLE, Vilany. MEC vai disponibilizar portal de livros para graduação. Mensagemposta da na lista de discussão Bib_virtual. Disponível em: http:// listas.ibict.br/pipermail/bib_virtual/2004-June/000190.html. Acesso em: 27 jul. 2005.

LATOUR, Bruno. Ciência em ação: como seguir cientistas e engenheiros sociedade afora. São Paulo: UNESP, 1999.

LATOUR, Bruno; WOOGLAR, Steve. A vida em laboratório: a produção dos fatos científicos. Rio de janeiro: Relume Dumará, 1997.

LÉVY, Pierre. As tecnologias da inteligência: o futuro do pensamento na era da informática. Rio de Janeiro: 34, 1993. 
LINS, Osman. Guerra sem testemunhas: o escritor, sua condição e a realidade social. São Paulo: Martins, 1974.

OLIVEIRA, Cláudia L. Cadernos universitários da ULBRA. Mensagem recebida por Flavia Goulart M. Garcia Rosa. Acesso em: 21 jul. 2005. [Mensagem pessoal].

ORGANIZAÇÃO DAS NAÇÕES UNIDAS. Declaração universal dos direitos humanos. Pro-clamada pela Assembléia Geral em 10 de dezembro de 1948. Disponívelem:http://www.camara.gov.br/cdh/Tratados_e_Convencoes/ declaracao_universal_dos_direitos_humanos.htm. Aces-so em: 20 jul. 2005.

PEREIRA, G.; MEMÓRIA, Maria L. R. A biblioteca, o bibliotecário e os direitos autorais frente às novas tecnologias informacionais. Revista Bibliomar, Maranhão, v.2, n.1, 2004. Disponível em: < http://www.ufma.br/canais/bibliomar/ edic_ant.htm>. Acesso em: 04 set. 2005.

UNIVERSIDADE DE SÃO PAULO. Resolução 5.213, de 2 de junho de 2005. Regula a extraçãode cópias reprográficas de livros, revistas científicas ou periódicos noâmbitoda Universidade de São Paulo. Diário Oficial do Estado, São Paulo, 2005. Disponível em: http://leg inf.uspnet.usp.br/resol/r5213m.htm. Acesso em:23 ago. 2005.

ZAID, Gabriel.Liwrosdemais!: sobre ler, escrevere publicar.São Paulo: Summus, 2004. 



\begin{tabular}{|c|c|}
\hline & ColofĀo \\
\hline Formato & $15 \times 21 \mathrm{~cm}$ \\
\hline Tipologia & $\begin{array}{l}\text { Aldine } 401 \text { BT 11/15 } \\
\text { Castle T e Castle T Lig }\end{array}$ \\
\hline Papel & $\begin{array}{l}\text { Alcalino } 75 \text { g/m² (miolo) } \\
\text { Cartão Supremo } 250 \mathrm{~g} / \mathrm{m}^{2} \text { (capa) }\end{array}$ \\
\hline Impressão & Setor de Reprografia da EDUFBA \\
\hline Capa e Acabamento & ESB - Serviços Gráficos \\
\hline Tiragem & 500 \\
\hline
\end{tabular}

